\title{
Ireland: Eighth Review Under the Extended Arrangement; Staff Report; Staff Supplements; and Press Release on the Executive Board discussion
}

The following documents have been released and are included in this package:

- $\quad$ The staff report, prepared by a staff team of the IMF, following discussions that ended on October 26, 2012, with the officials of Ireland on economic developments and policies. Based on information available at the time of these discussions, the staff report was completed on November 30, 2012. The views expressed in the staff report are those of the staff team and do not necessarily reflect the views of the Executive Board of the IMF.

- $\quad$ Supplements to the staff report providing an update on economic and policy developments, and on data released on residential mortgage arrears and repossessions.

- $\quad$ A Press Release on the Executive Board discussion.

The document(s) listed below will be separately released.

Letter of Intent sent to the IMF by the authorities of Ireland*

Memorandum of Economic and Financial Policies by the authorities of

Ireland*

Technical Memorandum of Understanding*

*Also included in Staff Report

The policy of publication of staff reports and other documents allows for the deletion of market-sensitive information.

Copies of this report are available to the public from

International Monetary Fund • Publication Services $70019^{\text {th }}$ Street, N.W. • Washington, D.C. 20431

Telephone: (202) 623-7430 • Telefax: (202) 623-7201

E-mail: publications@imf.org Internet: http://www.imf.org

\section{International Monetary Fund Washington, D.C.}


INTERNATIONAL MONETARY FUND

IRELAND

\section{Eighth Review Under the Extended Arrangement}

Prepared by the European Department

(In consultation with other departments)

Approved by Ajai Chopra and Lorenzo Giorgianni

November 30, 2012

Ireland's policy implementation has remained strong. The review focused on the budget for 2013 and on bolstering the framework for addressing loan arrears. The 2012 budget remains on track despite overruns in health and social welfare. Budget 2013 will target a deficit of 7.5 percent of GDP, requiring measures to address health overruns alongside a consolidation effort of 2.1 percent of GDP. The two structural benchmarks for the review were observed and agreement was reached on further measures to help contain and resolve loan arrears, including addressing hurdles to repossessions.

\section{However, Ireland's remaining vulnerabilities imply that prospects for durable} market access depend importantly on the delivery of European commitments. Market conditions for Irish sovereign debt are much improved following the announcements of the ESM direct bank recapitalization instrument and of OMT. But the feasibility of retroactive application of the ESM instrument for Ireland remains unclear as do the conditions for OMT qualification. Given Ireland's high public and private debt levels and uncertain growth prospects, inadequate or delayed delivery on these commitments poses a significant risk that recently started market access could be curtailed, potentially hindering an exit from official financing at end 2013.

While recognizing these risks, staff supports the authorities' request for completion of the eighth review. Management of the risks to market access, and hence to meeting the exceptional access criteria, depends on continued strong program performance and also on delivery of euro area commitments. The purchase subject to completing this review is equivalent to SDR 0.758 billion (about $€ 0.9$ billion).

Publication. The Irish authorities consent to publication of the Staff Report. 
I. Background

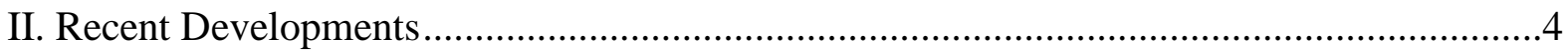

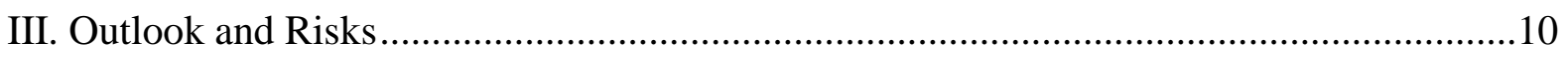

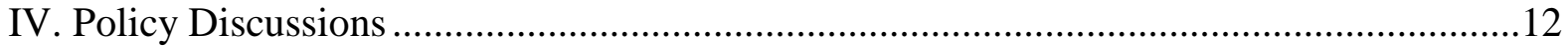

A. Fiscal Policy and Institutional Framework ………….............................................14

B. Financial Sector Reforms .................................................................................17

C. Enhancing Growth and Job Creation ...............................................................22

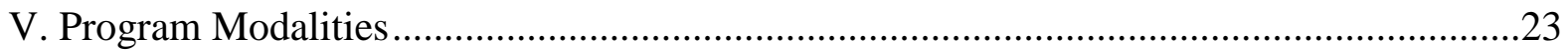

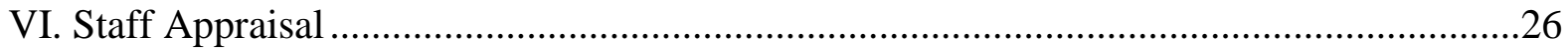

Boxes

1. Public Health Spending Over-Run: Sources and Policy Options ......................................... 9

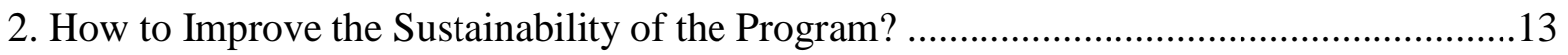

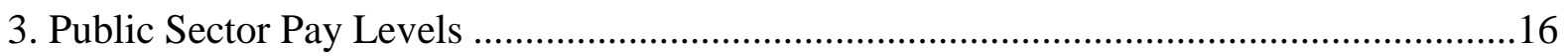

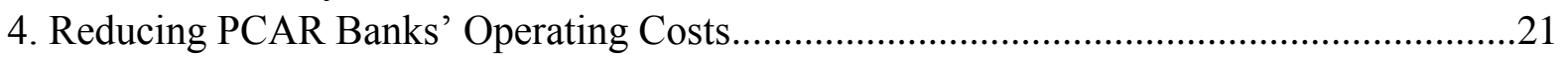

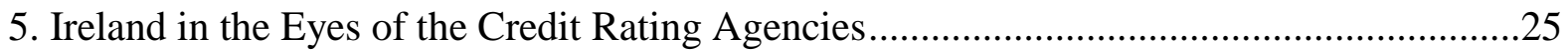

Figures

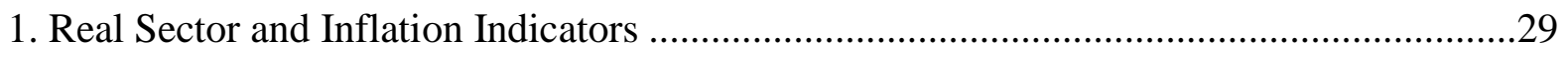

2. Household Finance and Housing Developments, 2001-12 ..............................................30

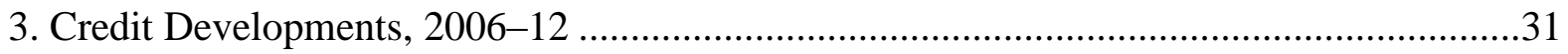

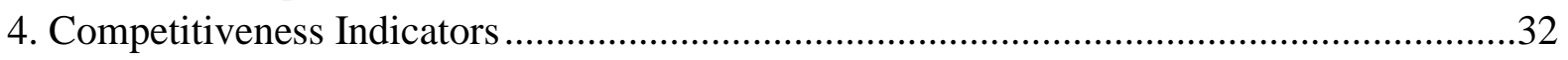

5. Selected Trends in General Government Finances ............................................................33

Tables

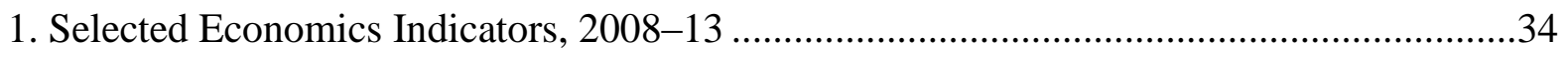

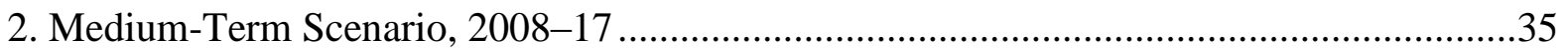

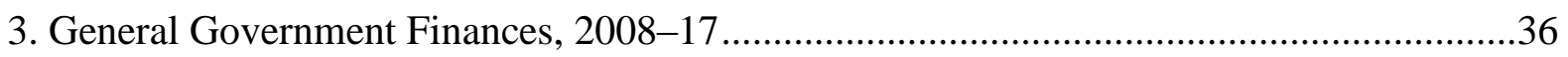

4. Indicators of External and Financial Vulnerability, 2008-12 ….........................................

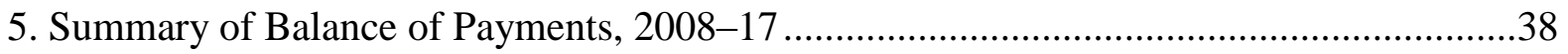

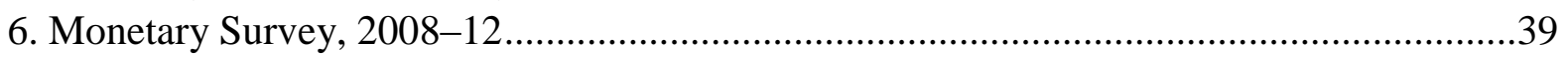

7. PCAR Banks' Aggregated Summary Financial Statements, 2011-12 …...........................40

8. General Government Financing Requirements and Sources, 2008-13 ..............................41

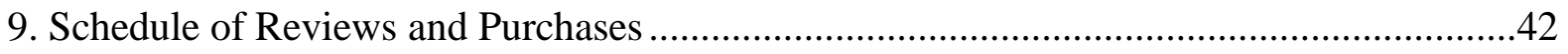

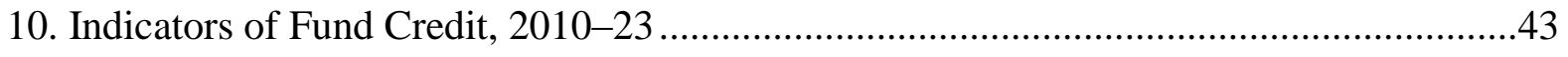


Annexes

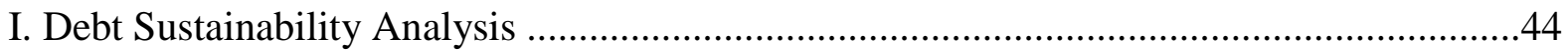

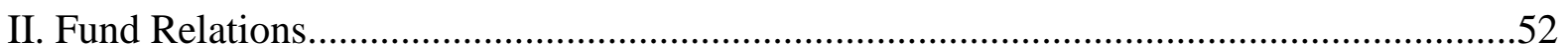

Attachments

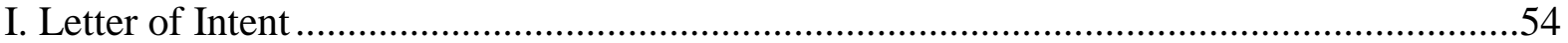

II. Memorandum of Economic and Financial Policies .......................................................57

III. Technical Memorandum of Understanding (TMU) ....................................................72

IV. Letter of Intent (European Commission) ............................................................... 78

V. Memorandum of Understanding on Specific Economic Policy Conditionality

(European Commission) . 


\section{BACKGROUND}

1. Ireland's steadfast policy implementation has continued. All quantitative macroeconomic targets for end-September 2012 were met (MEFP Table 2), and the two structural benchmarks for this review were observed. The budget remains on track towards the 2012 targets and financial sector and structural reforms are continuing to advance. Together with market expectations for supportive European policy action, this progress has enabled Irish sovereign yields to decline notably in 2012 and allowed Ireland to access significant market funding.

\section{Yet substantial challenges remain and prospects for Ireland to durably exit} official financing are strongly shaped by the timing and effectiveness of the delivery on European commitments. Public debt is expected to peak just over 120 percent of GDP and Ireland continues to face significant sovereign-bank linkages owing to the high cost of bank support and potential contingent liabilities from bank loan losses if growth were to remain weak in coming years. Delivery on European commitments, especially direct bank recapitalization, is therefore critical to ensure Ireland continues to deepen its access to markets in order to exit ongoing reliance on official financing.

\section{RECENT DEVELOPMENTS}

3. Benefitting from European policy announcements, Irish sovereign bond yields fell dramatically in the second half of 2012 and Ireland started to regain market access across a range of tenors. The notable spread narrowing after the June 29 euro area summit statement was followed by Ireland returning to the Treasury bill market within a week. Within a month, the authorities issued $€ 4.2$ billion in 5- and 8-year bonds at a weighted average yield of just under 6 percent. Irish bond markets, together with those of the euro area, were further bolstered by the ECB's announcement of Outright Monetary Transactions (OMT). The authorities sold $€ 1$ billion of 15-35 year amortizing bonds to local pension funds in August and Treasury bill issuance is now on a regular cycle. A September 25 German-DutchFinnish statement on direct ESM bank recapitalization interrupted this rally. It was followed by a joint declaration by

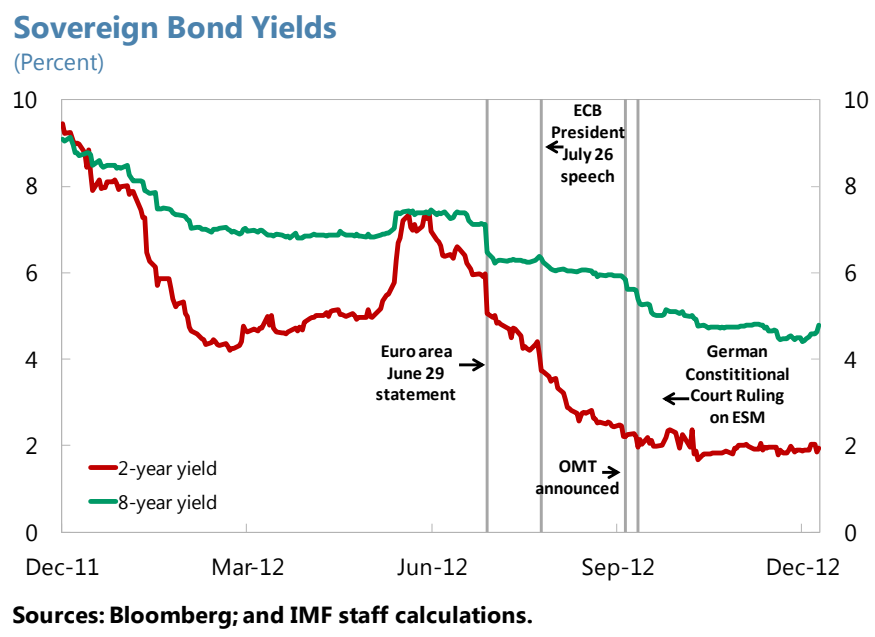
Chancellor Merkel and Prime Minister

Kenny on October 21 that Ireland is a special case. Overall, spreads on 2-year bonds have fallen 385 basis points from June 28, bringing yields down to 1.85 percent, while the longterm benchmark spread declined 270 basis points to bring yields to 4.45 percent. 


\section{Growth was weak in the first half of $\mathbf{2 0 1 2}$ with a continuing dichotomy between} external trade and domestic demand (Figure 1). Real GDP grew 1/2 percent y/y in H1 2012, in line with full-year expectations. ${ }^{1}$ Yet, domestic demand dropped $3 \frac{1}{2} 2$ percent $y / y$, primarily driven by private consumption falling $2^{1 / 4}$ percent and public consumption by $43 / 4$ percent. In contrast, net exports contributed $4 \frac{1}{4}$ percentage points to growth in $\mathrm{H} 1$ even as export growth eased to $3 \frac{3}{4}$ percent $y / y$ from 5 percent in 2011. A $2 \frac{1}{4}$ percent contraction in the volume of goods exports in the same period - the first fall since 2009-was responsible for this slowing, most likely due to weakness in the euro area and potentially a "patent cliff" in the pharmaceutical

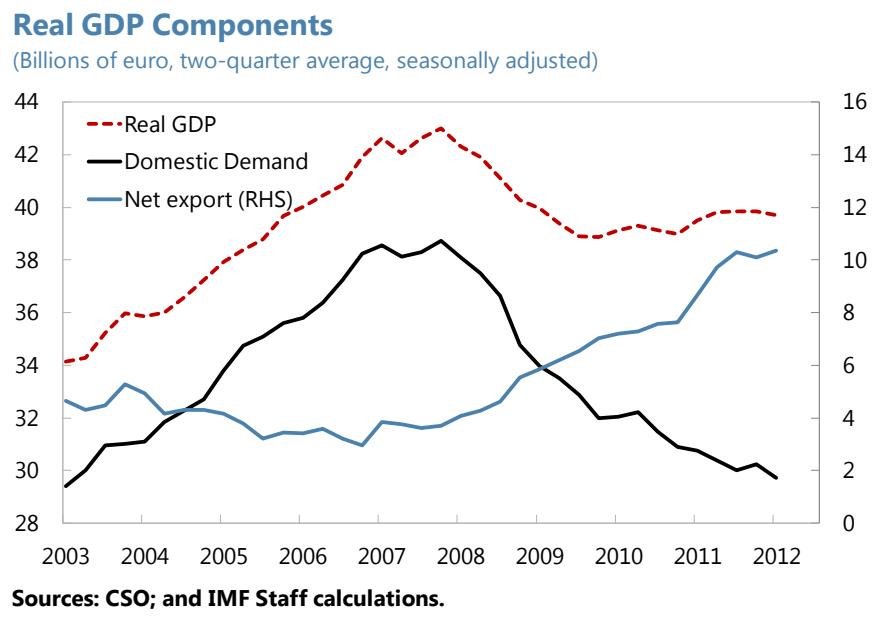
industry (nominal exports of pharmaceutical products fell $83 / 4$ percent). At the same time, services exports held up, exceeding goods exports for the first time. Lower net income outflows raised GNP growth to $2 \frac{1 / 4}{4}$ percent and lifted the current account surplus to 23/4 percent of GDP in $\mathrm{H} 1$, although there may be some unwinding in $\mathrm{H} 2$.

\section{Labor market conditions continued to deteriorate, though at a slowing pace.} Employment declined by 0.8 percent $y / y$ in the first three quarters of 2012, with the largest losses in construction, transport, industry, and public services while employment grew in services including accommodation and food, information and communication, and health. From a peak of 15 percent in Q1, the unemployment rate eased modestly to 14.8 percent in $\mathrm{Q} 3$, with around 60 percent without a job for more than a year and over one-third of youths in the labour force unemployed. The shrinking labor force, including as a result of outward Labor Market Impact of Employment Losses
(Changes in percent of working age population) migration, continued to act as a relief

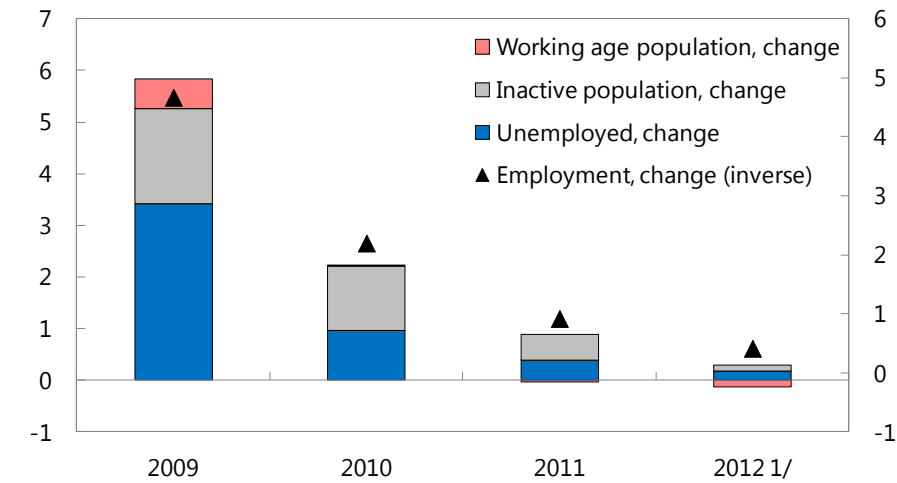

Sources: CSOI; and IMF staff calculations.

1/ Data for 2012 represents an average of the first two quarters. valve for unemployment; had all employees who lost their jobs since the outset of the crisis remained in the labor force, the unemployment rate would stand at around 20 percent.

\footnotetext{
${ }^{1}$ Irish GDP data are volatile, reflecting in part large flows channeled through multinational enterprises, which include major providers of internet services as well as major pharmaceutical companies.
} 


\section{The HICP inflation rate rose to around 2 percent during the first ten months of}

2012. Rapidly rising energy prices accounted for about 60 percent of the overall inflation rate. Core inflation (excluding energy and unprocessed foodstuffs but including indirect taxes) averaged 1 percent $y / y$ in the first ten months, compared with no inflation in 2011, reflecting the 2 percentage point increase in the main VAT rate, increases in the prices of services including insurance, and a weakening of the euro during the spring and summer months, which raised import prices.

\section{Household mortgage arrears continued to rise even as aggregate debt and debt} service burdens began to ease (Figure 2). High household savings are beginning to lower debt burdens, which nonetheless remain elevated at some twice household disposable income and 30 percent of household assets. Although early arrears have stabilized in recent months, the value of residential mortgages in arrears over 90 days continued to rise, reaching 14.7 percent of mortgage loans for principal dwellings at end-June. ${ }^{2}$ Moreover, provisional CBI data indicate that troubled residential mortgages for investment properties reached 28.9 percent. $^{3}$ National house prices have been broadly flat since April, slowing house price declines in October to 8.1 percent $y / y$, within the stress scenario under the 2011 Prudential Capital Assessment Review (PCAR). Housing market turnover, while still low, has picked up in 2012 and stocks of houses for sale have dropped. Repossessions and voluntary surrenders have remained very low, cumulating

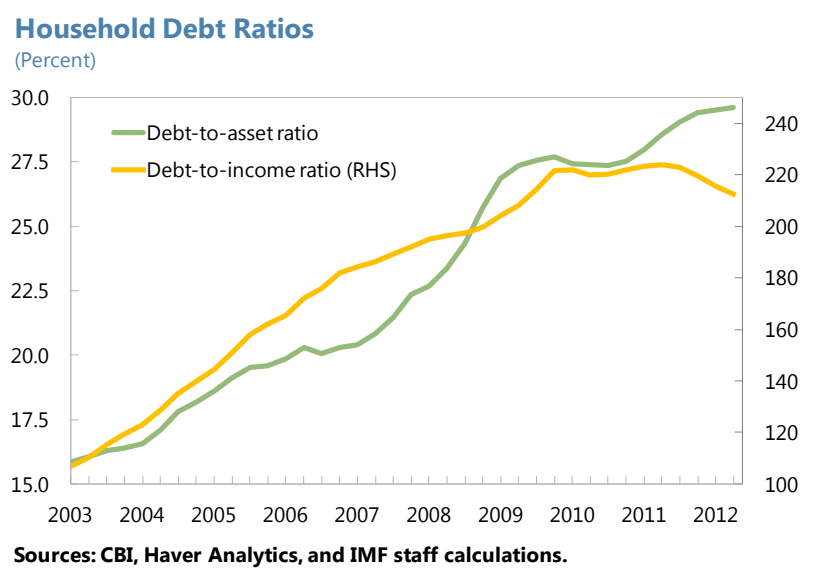
to $1 / 4$ percent of mortgages on owner occupied dwellings in the past three years.

8. Bank lending has remained weak (Figure 3). Lending flows have fallen to new lows, with gross mortgage loans to households down 10.3 percent $y / y$ in the first three quarters of 2012 and new SME loan drawdowns (excluding financial intermediation and property-related) down 20.7 percent y/y in first half. Interest rates on SME loans (proxied by loan agreements below $€ 1$ million) remain well above euro area average levels. The quarterly bank lending survey

\footnotetext{
${ }^{2}$ Research by the Central Bank of Ireland (CBI) suggests past job and income losses are the primary drivers for borrowers to fall behind on their mortgage payments.

${ }^{3}$ The outstanding amount of residential mortgages for investment properties was an estimated $€ 31.8$ billion in June 2012.
} 
indicates stable lending standards in Q3, aside from some tightening of consumer lending in recent quarters. Nonetheless, demand for mortgage loans is reportedly edging up in Q3, together with a rise in corporate sector loan demand.

\section{Funding conditions for Irish banks}

have shown signs of improvement following the renewal of sovereign bond issuance, yet funding costs remain high and access limited. The deleveraging of

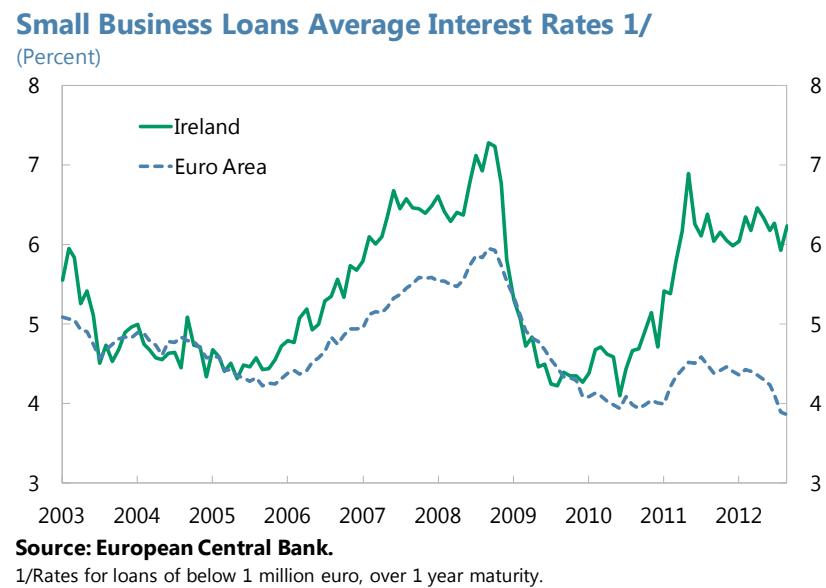

PCAR banks has progressed well in 2012, amounting to $€ 13.8$ billion by end September-bringing total deleveraging since December 2010 to $€ 50$ billion - although sales discounts have risen and deleveraging could become more challenging going forward. ${ }^{4}$ PCAR banks' borrowings from the Eurosystem continue to decline but remain large. Bank deposits have leveled out in recent months after rising earlier in the year, yet deposit rates have begun to decline though they remain well above euro area levels. Yields on bank bonds covered by the Eligible Liabilities Guarantee (ELG) scheme have fallen alongside declining government bond yields, illustrating the bank-sovereign link. Renewed Irish government bond issues have also improved the prospects for banks' market access, with interbank repos on Irish government securities - a funding channel closed since 2010 - recently restarting, and both BoI and AIB have recently issued 3-year maturity covered bonds without a state guarantee. ${ }^{5}$

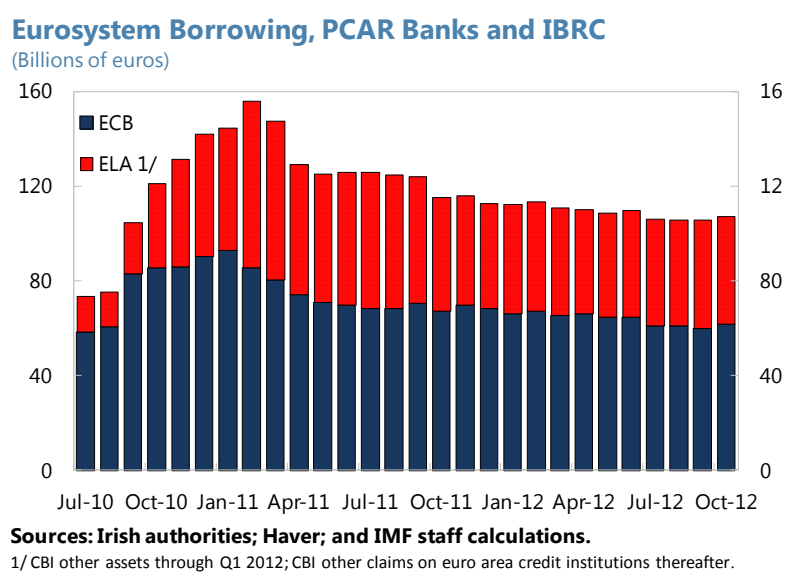

Sources: Irish authorities; Haver; and IMF staff calculations.
$1 /$ CBI other assets through Q1 2012; CBI other claims on euro area credit institutions thereafter.

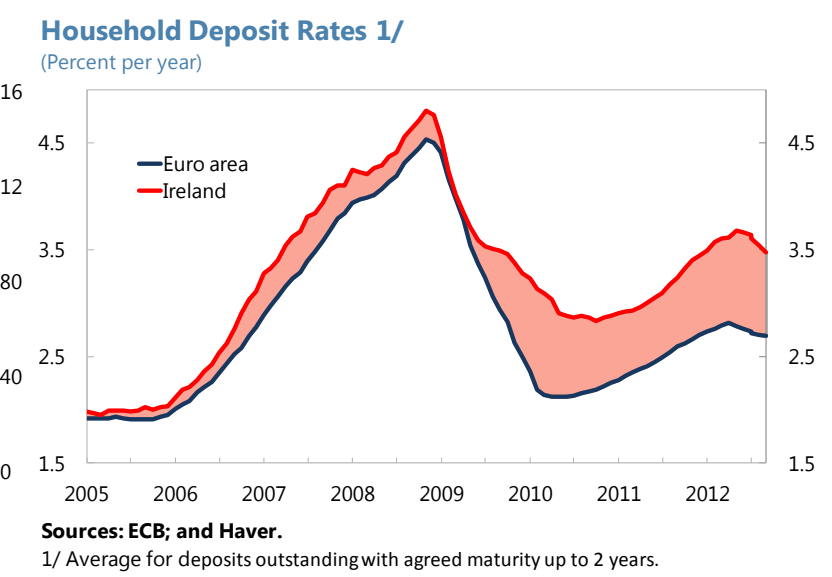

${ }^{4}$ The three PCAR banks are: Allied Irish Banks (AIB), Bank of Ireland (BoI), and Permanent TSB (PTSB), with public sector stakes of 99.9 percent, 15.2 percent and 99.0 percent, respectively.

${ }^{5}$ BoI issued on November 12 a 3-year covered bond collateralized with Irish mortgages, with an issue of $€ 1$ billion attracting $€ 2.5$ billion in bids at a spread 316 basis points over German bunds. BoI indicated that the proceeds would reduce its borrowing from the ECB. AIB's issue on November 28 of a $€ 500$ million 3-year covered bond also garnered broad demand from overseas investors at similar pricing. 
10. Domestic banks have high and rising impaired assets and remain unprofitable, which is eroding their currently strong capital buffers (Table 7). Gross non-performing loans have risen to 23 percent of PCAR banks gross loans at end September, up from 17 percent a year ago, with 50 percent provisioning coverage. For the first three quarters of 2012 , these banks reported a $€ 0.8$ billion pre provision loss excluding non-recurrent items (-0.3 percent of average assets) and, under their restructuring plans, they are not expected to break-even until 2014. Although these banks remain well capitalized, with Core Tier 1 ratios of 15.5 percent of risk-weighted assets and 7.5 percent of total assets, these buffers are expected to decline as loans are worked out and will be further eroded if operational losses persist.

\section{Asset disposals by the National Asset Management Agency (NAMA) are on track} and will be aided by stepping up asset realization strategies. Total asset disposals approved so far amount to $€ 10 \frac{1}{2}$ billion, with proceeds of $€ 6.2$ billion received, enabling NAMA to repay bonds in an amount of $€ 3 \frac{1}{4}$ billion to date, with additional redemptions expected before end 2012. To support its asset disposal and market restoration objectives, NAMA plans some $€ 2$ billion in capital projects in Ireland, phased in a back-loaded manner through 2016, with risks to be managed by limiting project exposure at any given time. NAMA will also make $€ 2$ billion of vendor financing available, which is expected to attract new investor equity in the order of $€ 0.6-0.9$ billion in 2013-14. The accompanying switch in credit risk from non-performing debtors to selected borrowers is expected to help to further lower risk on the overall commercial loan portfolio.

\section{Cumulative Exchequer Out-Turn Vs. Authorities' Profile - January-October 2012}
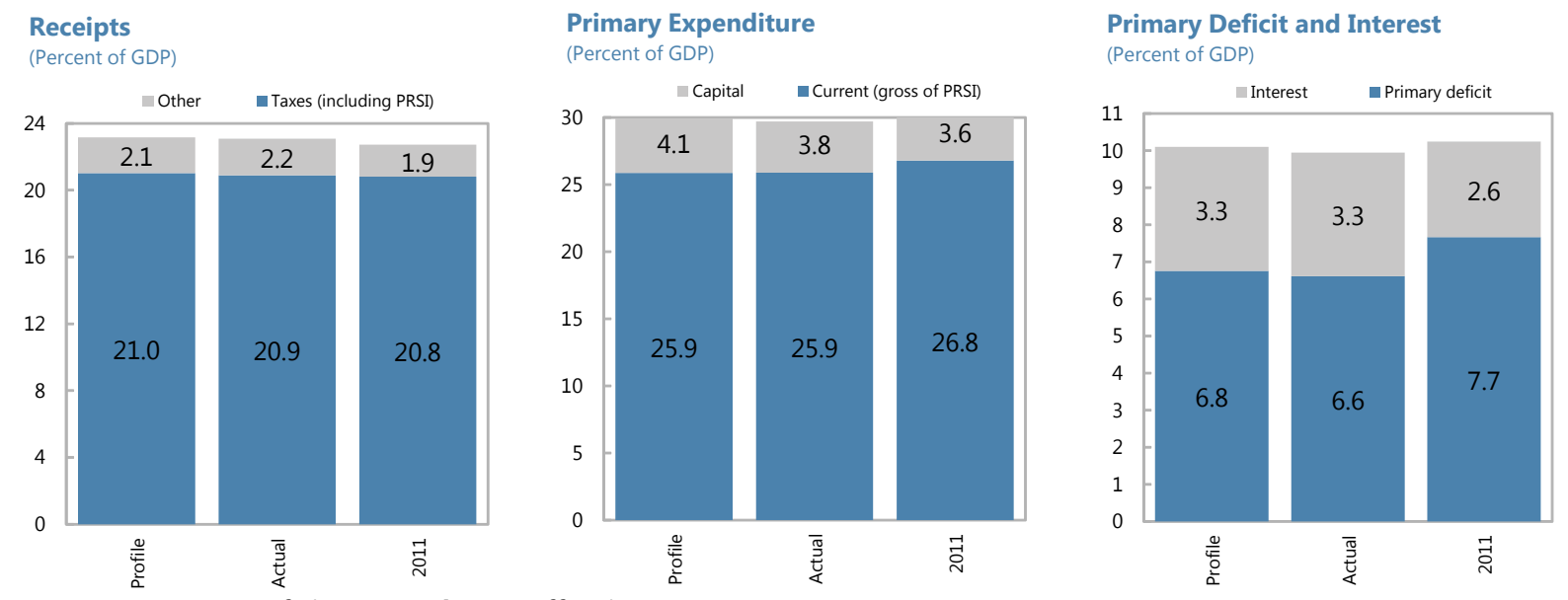

Sources: Department of Finance; and IMF staff estimates.

PS: To facilitate comparability, (i) the $€ 251$ million corporation tax payment delayed from December 2011 into January 2012 is excluded from both the 2012 tax profile and outturn; (ii) the $€ 548$ million in interest payments met in Jan-Oct 2011 via drawdown of the Capital Services Redemption Account (CSRA) are included in the 2011 exchequer interest bill; (iii) symmetric entries of $€ 646$ million in respect of the Sinking Fund in March 2012 - recorded as current spending and other receipts (capital receipts) — are taken out; (iv) the IBRC promissory note payment of $€ 3.06$ billion that was settled through bond issuance is included in capital expenditure for 2012; (v) a $€ 110$ million exchequer-improving recoupment of a Social Insurance Fund advance is excluded from 2011 current spending; (vi) the ILP payment of $€ 1.3$ billion is excluded from 2012 capital spending; and (vii) about $€ 1$ billion in one-off proceeds arising from the sale of the state's shareholding in the Bank of Ireland is excluded from 2011 other receipts (capital receipts). 


\section{Fiscal performance through October was on track despite current spending} pressures in some areas. At 6.6 percent of GDP, the exchequer primary balance in the first ten months of 2012 was 1.1 percentage points below the same period last year and 0.2 percentage points inside the authorities' profile. Revenues are on-profile, with a softening in direct taxes in October (mainly corporation tax) offsetting the robust performance in VAT and other (non-tax) receipts. Most recently, the authorities have sold the UMTS telecommunications spectrum license for 0.2 percent of GDP more than budgeted, which will commensurately boost 2012 capital receipts and the general government balance. Primary expenditure is within the budgetary envelope, but overruns in health and social welfare, together with an anticipated partial unwinding of under-spends, especially in the capital budget, may test the aggregate expenditure limits. The 0.1 percent of GDP overrun in gross social welfare spending is mainly on account of unemployment above budget assumptions. The drivers of the health overspend - projected at 0.3 percent of GDP for 2012 — are of a more structural nature (Box 1).

\section{Box 1. Public Health Spending Over-Run: Sources and Policy Options}

Source of overrun: Net health sector spending is expected to be about $€ 0.5$ billion ( $4 \frac{1}{2}$ percent or 0.3 percent of GDP) above budget in accrual terms. The overspending is distributed broadly evenly across:

- The pay and pensions bill: This overrun reflects higher-than-expected early retirementsincluding of staff already on career breaks and deferred pensions - and hiring of agency workers to replace retiring staff. Higher agency costs also reflect pre-existing challenges in managing hospital activity and costs to budgeted levels.

- Non-pay hospital expenses (net offees collected): Management issues were also the main reason for overruns in the hospital sector, with shortfalls in fees from private patients also contributing.

- Subsidies in relation to medical cards: Key drivers of the over-spend included higher than budgeted: (i) number of medical cards; and (ii) number and average cost of drugs per subscription, especially in relation to elderly patients.

Budget correction: The authorities are committed to durably unwinding the over-run by bringing the 2013 gross health expenditure to below the previously-set ceiling of $€ 13.6$ billion. Although challenging politically, a number of measures can deliver the required savings, without affecting service provision (Ireland's health spending is one of the highest in OECD, but health outcomes are near average).

Policy options: On the pay bill, there are options to reduce overtime and premium payments through substantially-improved work practices and rostering arrangements for key groups; this would also enable broader hospital efficiencies, such as fewer weekend stays of healthy patients. A recent agreement will reduce the cost of pharmaceuticals over four years, but more substantial savings on drug costs are needed by sharply raising usage of generics, estimated by the OECD at less than one-fifth of prescription volume (the second lowest among OECD economies). Expenditure on medical cards, which are held by 40 percent of the population, with nearuniversal coverage of persons over 70 , could be better targeted; options include a more effective means-test to establish eligibility for the over-70s, more graduated coverage of services (such as GP-only medical cards), and higher co-payments. Finally, there is scope for increased cost recovery in respect of private patients' use of public hospitals. 


\section{OUTLOOK AND RISKS}

13. Growth in real GDP is expected to be low, at just under $1 / 2$ percent in 2012 , but is still subject to uncertainty given recent mixed signals. While developments in $\mathrm{H} 1$ were broadly as expected, the indicators available for $\mathrm{H} 2$ are mixed. ${ }^{6}$ On balance, projected export growth of 2.8 percent remains achievable in 2012, with net exports still the sole driver of growth. As the collapse of investment slows and the pace of contraction in private and public consumption eases the decline in domestic demand is expected to be smaller than in 2011. With employment contracting by $1 \frac{1 / 4}{4}$ percent the rate of unemployment is expected to average 143/4 percent while inflation remains at about 2 percent. In their Medium Term Fiscal Statement (MTFS), the authorities project somewhat higher growth, with larger net exports raising growth to 0.9 percent in 2012, and stronger investment increasing growth to 1.5 percent in 2013 .

Ireland: Macroeconomic Projections, 2008-15 (percentage change, unless otherwise indicated)

\begin{tabular}{lcccccccc} 
& 2008 & 2009 & 2010 & 2011 & 2012 & 2013 & 2014 & 2015 \\
\hline Real GDP & -2.1 & -5.5 & -0.8 & 1.4 & 0.4 & 1.1 & 2.2 & 2.8 \\
Real domestic demand & -3.7 & -11.0 & -4.2 & -3.7 & -2.9 & -0.9 & 0.9 & 1.7 \\
$\quad$ Private consumption & -0.1 & -5.4 & 1.0 & -2.4 & -2.1 & -0.5 & 1.2 & 1.8 \\
$\quad$ Public consumption & 0.6 & -4.4 & -6.5 & -4.3 & -4.0 & -2.0 & -1.3 & -1.0 \\
$\quad$ Fixed investment & -10.0 & -27.6 & -22.6 & -12.6 & -4.0 & -1.5 & 3.0 & 5.2 \\
$\quad$ Change in stocks 1/ & -1.2 & -0.7 & 0.6 & 0.5 & -0.1 & 0.0 & 0.0 & 0.0 \\
Net exports 1/ & 1.4 & 4.5 & 3.0 & 5.4 & 2.7 & 1.8 & 1.6 & 1.5 \\
$\quad$ Exports & -1.1 & -3.8 & 6.2 & 5.1 & 2.8 & 3.2 & 4.2 & 4.5 \\
$\quad$ Imports & -3.0 & -9.7 & 3.6 & -0.3 & 0.3 & 2.1 & 3.7 & 4.2 \\
Nominal GDP (in billions of euros) & 178.9 & 161.3 & 156.5 & 159.0 & 162.3 & 166.2 & 172.3 & 179.9 \\
GDP deflator & -3.2 & -4.6 & -2.2 & 0.2 & 1.6 & 1.3 & 1.4 & 1.6 \\
Current account (in percent of GDP) & -5.7 & -2.3 & 1.1 & 1.1 & 2.3 & 3.1 & 3.8 & 4.0 \\
Consumer Prices (HICP) & 3.1 & -1.7 & -1.6 & 1.2 & 2.0 & 1.3 & 1.4 & 1.6 \\
Unemployment rate (in percent) & 6.4 & 12.0 & 13.9 & 14.6 & 14.8 & 14.7 & 14.2 & 13.4 \\
\hline I/Contrbutions to growth & & & & & & &
\end{tabular}

$1 /$ Contributions to growth

14. The baseline scenario is for a gradual recovery assuming continued progress in resolving the euro area crisis, but the pace of recovery has been marked down given weaker trading partner growth prospects. Projections for Ireland's GDP growth in the next two years have been revised down by 0.3 percentage points to 1.1 percent in 2013 and 2.2 percent in 2014. A reduction in WEO projections for growth in Ireland's trading partners from 1.3 percent to 0.9 percent in 2013 is a key factor. Domestic demand is expected to decline in 2013 by a further 1 percent and to grow around 1 percent in 2014. This gradual

\footnotetext{
${ }^{6}$ Core retail sales volumes grew 11/4 percent y/y in July-October but consumer confidence fell in September. After rising by 1.7 percent $y / y$ on average during the first 8 months of 2012, the volatile industrial production series dropped almost 13 percent in September, and it remains to be seen whether this fall concentrated in pharmaceuticals is temporary or lasting. In contrast, goods exports rose 63/4 percent $y / y$ in nominal terms in Q3, new export orders remained above the 50 percent benchmark until September, and the October services PMI rose to the highest level in five years.
} 
revival hinges crucially on continued progress in addressing the euro crisis - including through implementation of policies that ease financial conditions further in countries facing stress, while articulating a credible path to greater integration - in order to reduce consumer and business uncertainties that hold back demand. It also requires progress in addressing debt distress and reviving credit growth needed to support recovery of investment from current depressed levels. By 2015, growth builds to almost 3 percent in the baseline, as competitiveness will further improve through low wage growth and as the benefits of reforms to address the Irish economy's relatively limited structural challenges begin to be realized. However, unemployment declines only gradually over the medium term, in part reflecting an expected slowing of emigration as entry into unemployment diminishes.

15. This gradual recovery faces impediments that pose significant risks. Net exports, still the sole engine of growth, are naturally sensitive to any further weakening in trading partner activity. A sustained recovery that generates sufficient job creation also requires a revival of domestic demand, which faces a range of hurdles that create substantial uncertainty around prospects beyond the near-term:

- Financial reform benefits. In the wake of an exceptionally deep financial crisis, with impacts across the system, financial sector reform challenges remain substantial, and there is uncertainty around the timing and magnitude of the benefits of financial sector reforms for reviving banks' profitability and capacity to lend to households and SMEs.

- Debt overhangs. Government debt is set to peak at some 122 percent of GDP, household debt is 209 percent of disposable income, and many SMEs are burdened by property-related loans. These debts drag on growth through private deleveraging, reduced access to credit at higher cost, and concerns about future tax burdens.

- Bank-sovereign loop. These debt stocks are compounded by still large contingent liabilities from the banking system in a scenario where weak growth reduces asset values and heightens loan losses. As a result, the challenges for sovereign and banks in accessing market funding are interlocked, magnifying the growth uncertainties.

- Fiscal drag. Fiscal consolidation will continue to be significant in coming years, with the growth impact depending on the composition of measures and also on external economic conditions and progress in easing credit constraints.

16. These risks to growth have profound adverse implications for debt sustainability (Annex I). Under the baseline scenario, Ireland's public debt is projected to peak at 122 percent of GDP in 2013 and then decline to 112 percent by 2017 . $^{7}$ This downtrend in debt over the medium term is contingent on a pick-up in GDP growth and the avoidance of additional fiscal costs from the financial sector support; if the above hurdles to domestic demand keep growth in check, say at $1 / 2$ percent in coming years, Ireland's debt ratio would

\footnotetext{
${ }^{7}$ The upward shift from the seventh review reflects the authorities' plans to hold a strong cash buffer to facilitate the transition to relying on market funding (see Section V).
} 
continue to rise. Leaning against such developments with additional fiscal consolidation may help slow down the rise in the debt ratio, but would further reduce growth and raise unemployment and increase risks of hysteresis. Moreover, the resulting higher loan losses would generate new capital needs once banks' buffers are exhausted, which could raise debt ratios in the medium term, heightening the challenges to recovery. Such setbacks in Ireland would exacerbate the broader euro zone crisis.

\section{In these circumstances, Ireland's market access is fragile, and relies crucially on} the strength of program implementation, together with forceful delivery on European commitments. The most definitive means to improve the sustainability of Ireland's program, as committed by euro area leaders on June 29, would be through ESM equity participation in the banks, which would sever the sovereign's exposure to contingent liabilities from the banks, reduce public debt directly, resuscitate bank funding conditions and help revive domestic credit and economic growth, and thus underpin successful exit from the program (Box 2). Markets have priced-in ongoing strong program performance and delivery on European commitments, yet reports of diverse views among EU member states indicate uncertainties regarding the nature, timing, and efficacy of their implementation. Disappointing these expectations risks further reliance on official financing, which could become prolonged as the rising share of official financing would raise subordination concerns and diminish prospects for the sovereign to regain market access. ${ }^{8}$

\section{Policy Discussions}

\section{In order to deepen Ireland's market access, discussions focused on policy actions} to support confidence that key fiscal, financial sector, and growth challenges are being addressed. Key issues for the review are Budget 2013 - a prior action for completion - and the update of the medium-term fiscal consolidation plan. In the financial sector, the focus is on implementation of steps to arrest the deterioration in asset quality and reinforcing PCAR banks efforts to restore profitability and support the ongoing recovery. Discussions on structural reforms focused on job creation and containing structural unemployment.

\footnotetext{
${ }^{8}$ In the event market access is not regained, Ireland is expected to continue to receive European financial support under the EU Head of State and Government July 2011 commitments, reiterated in the October 2011 Euro Summit Statement, to "continue providing support to all countries under programmes until they have regained market access, provided they fully implement those programmes."
} 


\section{Box 2. How to Improve the Sustainability of the Program?}

Euro area leaders' made welcome commitments to improve the sustainability of the Ireland's program. On June 29, 2012, euro area leaders stressed the imperative of breaking the vicious circle between banks and sovereigns; introduced the possibility of the ESM recapitalizing banks directly following the establishment of a single euro area supervisory mechanism involving the ECB; and pledged to examine the situation of the Irish financial sector with the view of further improving the sustainability of the well-performing adjustment program. The ECB's OMT is also a welcome step, yet current program countries lack sufficient market access to be eligible at this time.

Although a combination of tools will be needed to cement Ireland's market access and thus assure successful exit from the program, ESM bank equity participation can play a key role in enhancing sustainability. Such participation would (i) sever the link between the government and the banks, cutting through the contingent liability uncertainty overhang; (ii) reduce the high debt stock directly; and (iii) support economic recovery by providing banks the assurance of a financially strong owner, thereby enhancing their access to market funding and ability to lend.

To be effective, the ESM needs to act as the quintessential patient investor while exercising prudence in asset valuations. In valuing banks in which it participates, an approach which assesses the economic value over the long term (rather than the 2-3 year horizon of a stress test) will allow time for bank restructuring efforts and economic recovery to enhance bank profitability. Assessments of prospective profitability should also internalize the benefits of ESM ownership for bank funding costs. At the same time, prudent asset valuations - ideally by independent parties - are critical to achieve euro area leaders' goals. Such an approach allows the option to retain impaired assets in the bank while safeguarding against fiscal transfers; this is desirable because the alternative of segregating all impaired assets into recovery vehicles ultimately backed by the taxpayer would preserve, not break, the bank-sovereign loop.

ESM equity may take time to become available, so a bridge is needed to safely reach that point. Market conditions have improved, but Ireland requires substantial market financing in 2013, ahead of program exit, and beyond. Three additional elements can help shore up Ireland's smooth exit from reliance on official financing:

- Promissory notes. In the near-term, the security of Ireland's market access would benefit from progress on dealing with the heavy amortization schedule on the government's $€ 28 \frac{1}{2}$ billion promissory note debt held by the Irish Bank Resolution Corporation.

- $\boldsymbol{O M T}$. Ireland is building up a track record of market access. Outright monetary transactions would help cement this market access against potential new external stresses.

- Financing backstops. If needed to safeguard market access, including by ensuring potential for OMT availability, options for backstops to succeed the existing EU-IMF supported program when it expires at end 2013 could also be explored.

Firm delivery on commitments opens the prospect of moving Ireland into a virtuous circle for recovery. With investment depressed, there is the potential for renewed confidence to drive growth above the baseline, with Ireland's success having positive spillovers for the euro area. 


\section{A. Fiscal Policy and Institutional Framework}

\section{A general government deficit of $\mathbf{8} 1 / 4$ percent of GDP is projected for 2012, within} the program ceiling of 8.6 percent (MEFP $1[3) .{ }^{9}$ A combination of slower growth, higher unemployment, and the over-run in health spending, have dimmed prospects for any significant fiscal over performance in 2012. Indeed, given the weak economic conditions, only about half of the 6 percent of GDP consolidation effort over 2011-12 has translated into headline primary balance improvement. Nonetheless, the authorities' consistent achievement of the original program fiscal targets despite adverse macroeconomic conditions gives confidence in their institutional capacity and commitment to consolidation.

20. In their updated MTFS, the authorities have reaffirmed their consolidation effort of $€ 8.6$ billion (5 percent of GDP) in 2013-15 (MEFP I[4-6). The consolidation will continue to be led by current spending, but with revenues contributing close to 40 percent of the savings. It will also be phased, easing from $€ 3.5$ billion (2.1 percent of GDP) in 2013 to $€ 2$ billion (1.1 percent of GDP) by 2015. This consolidation path is underpinned by multi-annual departmental expenditure limits through 2014 that were set last December. In particular, bringing health spending within its 2013 ceiling will require a range of additional structural

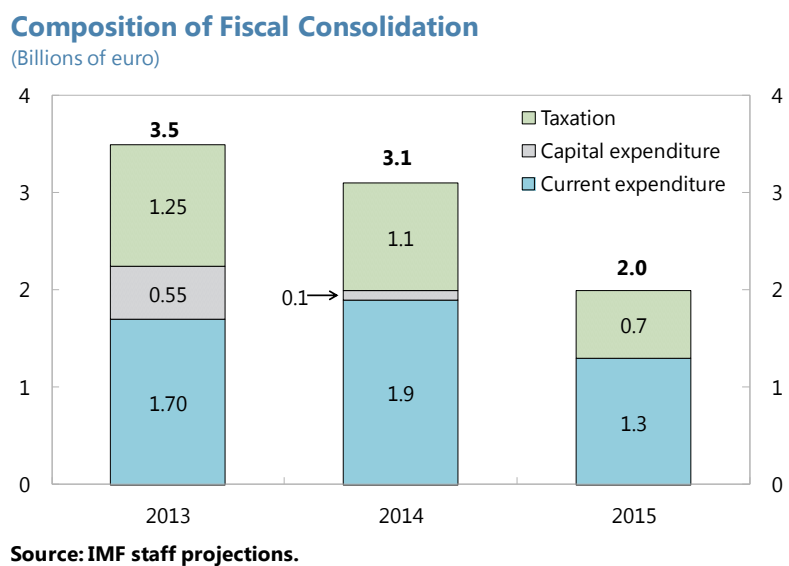
measures to unwind the 2012 over-spend (Box 1). To further ensure the delivery of a deficit within the Excessive Deficit Procedure (EDP) ceiling of 7.5 percent of GDP in 2013, the MTFS provides for additional general government balance improvements of at least 0.3 percent of GDP, including a commitment to ensure a balanced budget in 2013 in the local government sector. Net proceeds from the sale of non-financial assets not covered under the state asset disposal program, and favorable accrual adjustments from property tax deferrals, are expected to constitute the remainder.

\section{The medium-term consolidation path set out in the MTFS is appropriate and} effective implementation of the structural reforms needed to underpin this path will be paramount. Given the still-fragile recovery, undertaking additional consolidation in 2013 is not favored if growth should prove to be weaker than projected, especially as Ireland's fiscal multipliers - which are expected to be lower than average given the highly open economymay be higher than typical owing to limited credit availability. Hence, a flexible approach is

\footnotetext{
${ }^{9}$ The end-September 2012 performance criterion on the cumulative exchequer primary balance was met with a margin of $€ 1.2$ billion ( 0.8 percent of GDP), after adjusting upward for revenue over performance of $€ 0.5$ billion, and downward by $€ 1.3$ billion in bank support costs (acquisition of Irish Life). The net central government debt target was achieved by a margin of 1.5 percent of GDP (MEFP, Table 2).
} 
preferred regarding the path toward the 2015 deficit target, such as by deferring any significant additional consolidation to 2015 where the adjustment burden is lighter. Such flexibility will have a marginal impact on debt sustainability but entail substantial benefits for the political feasibility and credibility of consolidation. At the same time, staff urges vigilance in ensuring the efficacy of structural reforms to underpin durable expenditure savings, especially in the health sector, to protect confidence in the medium-term consolidation goals.

Ireland: General Government Finances, 2010-15 1/

(In percent of GDP unless otherwise stated; excluding bank support costs)

\begin{tabular}{|c|c|c|c|c|c|c|}
\hline & 2010 & 2011 & 2012 & 2013 & 2014 & 2015 \\
\hline Net lending/borrowing (General government balance) & -10.7 & -9.1 & -8.3 & -7.5 & -5.0 & -2.9 \\
\hline Primary balance & -7.6 & -5.9 & -4.4 & -1.8 & 0.6 & 2.7 \\
\hline Structural primary balance (percent of potential GDP) & -6.2 & -4.5 & -2.6 & 0.3 & 2.1 & 3.5 \\
\hline Structural balance & -9.6 & -7.8 & -6.6 & -5.4 & -3.5 & -2.1 \\
\hline Programmed consolidation commitments 2/ & & 3.3 & 2.6 & 2.1 & 1.8 & 1.1 \\
\hline Real GDP growth (percent) & -0.8 & 1.4 & 0.4 & 1.1 & 2.2 & 2.8 \\
\hline Unemployment rate (percent) & 13.6 & 14.4 & 14.8 & 14.7 & 14.2 & 13.4 \\
\hline Net general government debt & 74.5 & 94.9 & 103.7 & 107.3 & 109.1 & 107.6 \\
\hline
\end{tabular}

$1 /$ Projections are consistent with staff's macroeconomic baseline and the programmed consolidation path set out in the Updated MTFS, including authorities' commitment to unwind the 2012 health overspend in 2013; and implement additional GGB improvements of 0.3 percent of GDP.

2/ Carryovers from revenue measures are included.

22. The authorities are finalizing their consolidation package for $2013 .{ }^{10}$ Budget 2013 would include $€ 1.7$ billion in expenditure measures and $€ 1$ billion in new revenue measures. ${ }^{11}$ The authorities are considering options that could generate immediate and durable savings, while being growth-friendly and effectively protecting the most vulnerable:

- On the current expenditure side, the authorities plan to reduce spending on universal social benefits (e.g., child benefit) and subsidies (e.g., tertiary education), with effective means-tested offsets for welfare recipients and low-income earners. Also under review are options to address the significant fiscal implications of population ageing, as highlighted in the recent actuarial review of the Social Insurance Fund. In relation to public pay - which includes a significant premium over private sector pay (Box 3) - the authorities have begun to engage with public sector unions to secure significant additional wage and pension bill savings in the period to 2015 , including through additional structural productivity reforms relating to hours worked. Together with plans to cut personnel numbers by another $3 \frac{1}{2}$ percent over the next two years, these measures will deliver significant public wage bill reductions.

\footnotetext{
${ }^{10}$ Budget 2013 is scheduled to be submitted to parliament on December 5. A supplement to the staff report will provide a more detailed discussion and assessment of the fiscal measures.

11 These amounts exclude $€ 0.55$ billion in capital savings already announced last year; $€ 0.22$ billion in carryover from previously adopted revenue measures; measures of 0.3 percent of GDP to address the 2012 health overspend; and additional general government balance improvements of 0.3 percent of GDP.
} 


\section{Box 3. Public Sector Pay Levels}

A recent report by Ireland's Central Statistics Office (CSO) comparing pay in the public and private sectors documents a significant public wage premium, especially at the lower ends of the earnings distribution. Using

appropriately weighted data to capture the representative worker, and controlling for differences in the characteristics of public and private workers (including that public employees, on average, are more highly educated), the CSO provides a range of estimates of underlying public-private wage divergences. The set of baseline estimates favored by staff suggest a wage premium of 14 percent for a public sector employee earning the median wage relative to the private

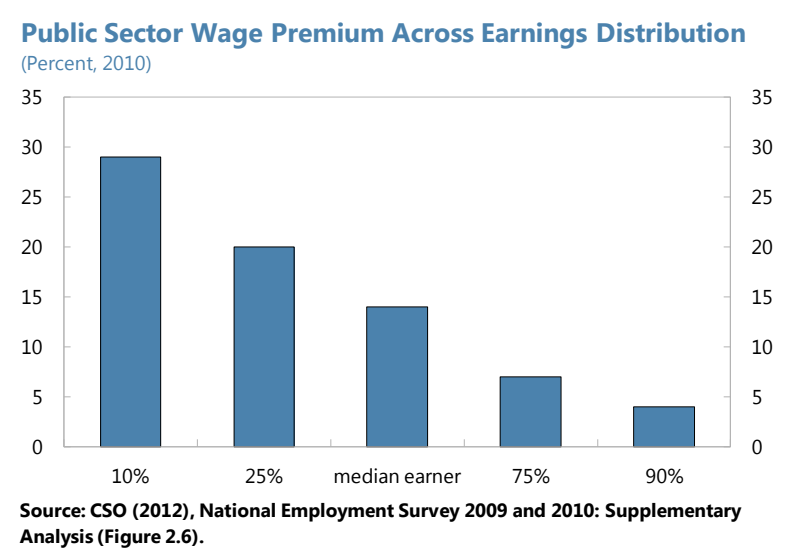
sector. ${ }^{1}$ The premium is larger at lower salary levels, being 20 percent for the $25^{\text {th }}$ percentile compared with 7 percent at the $75^{\text {th }}$ percentile. These estimated premia would likely narrow by about 7 percentage points if account is taken of the pension-related deduction introduced in 2009 (essentially a progressive pay cut for public sector workers), and a further 2 percentage points if state-owned enterprise employees (who earn higher salaries than the rest of the public sector) are excluded. In sum, although significantly narrowing from 2007 due to the $13 \frac{1}{2}$ percent average net pay reduction over 2009-10, these estimates indicate a public wage premium remains for the majority of public employees, especially at the lower ends of the earnings distribution. ${ }^{2}$

Evidence from cross-country comparisons of public compensation supports this conclusion. ${ }^{3}$ Staff has previously noted that Ireland's share of public compensation in government expenditure and the ratio of average public pay to per capita GNP are among the highest in the OECD $\left(6^{\text {th }} \mathrm{EFF}\right.$ review, Box 5; and Ireland - Selected Issues, Section III.D). OECD's at-a-glance reports on the government sector and on education and health find that public pay in Ireland is elevated, especially for school teachers and medical professionals.

\footnotetext{
${ }^{1}$ These estimates are based on regressions that exclude firm size as a separate control variable (its inclusion reduces the estimated premium to about 6 percent for the median worker). Staff considered possible arguments for including this control, such as that larger firms are more capital-intensive and need more highly-skilled and educated workers to operate; and that monitoring of work effort is harder in bigger firms thus necessitating efficiency wage premia. However, given that controls for education and skill are already included in the regressions, and that failure to correctly specify firm size for all public sector workers is likely to bias results (for e.g., by over estimating monitoring costs for public school teachers), staff favors regressions excluding firm size as an additional control.

${ }^{2}$ The analysis excludes difficult-to-quantify factors such as greater job security, relatively generous definedbenefit pensions and better leave arrangements enjoyed by the public sector, which would suggest that the underlying public wage premium is higher. At the same time, some of the observed premium can be explained by the public sector's better equal-pay policies for female workers, who account for almost twothirds of the public service.

${ }^{3}$ Cross country comparisons are useful as public-private pay comparisons are necessarily difficult because of the lack of comparators in the private sector for tasks primarily performed in the public sector (such as by teachers and nurses, or in the public safety and defense sectors).
} 
- On the revenue side, the authorities have announced plans to introduce, from mid2013, a property tax on the value of private residences, featuring few exemptions, and to be collected by the central revenue agency, which has a proven collection capacity. ${ }^{12}$ The tax is expected to be progressive, with a relatively low multiplier for domestic demand and low impact on work or investment incentives, and will constitute an important and stable source of revenue for government. A number of base-broadening reforms in personal income taxation - including social security contributions - are also being pursued with the aim of better targeting existing tax reliefs to lower-income groups. On indirect taxes, the authorities are aligning the $\mathrm{CO}_{2}$ bands for environmental-related vehicle taxes with advancements in green technology, and considering higher excises on alcohol.

23. The authorities should outline the remaining consolidation measures for 2014-15 around the time of Budget 2013 (MEFP 98 ). The program envisages additional consolidation of 3 percent of GDP over 2014-15. Taking into account the measures already specified for these years (such as on capital spending), and carryover savings from earlier measures, new measures of about $1 \frac{1}{2}$ to 2 percent of GDP remain to be identified for 2014-15. To maximize the credibility of fiscal consolidation, and to reduce household and business uncertainties, the authorities should set out directions for some of the deeper reforms that will deliver this effort. These could include, for instance, on the revenue side, reforming tax reliefs on private pension contributions; and on the expenditure side, greater use of generic drugs and primary and community healthcare, and an affordable loan scheme for tertiary education to enable rising demand to be met at reasonable cost.

24. Institutional fiscal reforms are progressing as expected. The Fiscal Responsibility Bill published in July was signed into law at end November. The law provides a statutory basis for the independence and adequate funding of the Irish Fiscal Advisory Council and adopts a structural balance rule and a debt reduction rule. The already operational multiannual expenditure ceilings have been included in separate legislation - the Ministers and Secretaries (Amendment) Bill 2012 - with operational details (such as contingencies, carryover provisions etc.) to be published at the same time as the Bill is enacted. The authorities continue to enhance fiscal transparency: an analytical monthly exchequer report was published in September, and the Central Statistics Office is preparing to launch a new stand-alone Government Finance Statistics publication from April 2013.

\section{B. Financial Sector Reforms}

25. The financial sector is still recovering from deep wounds. The PCAR banks have fallen into underlying losses in the first half of 2012 after just breaking even in 2011. Key factors contributing to these losses are high funding and operational costs and the exceptional scale of non-performing assets which generate reduced income; PCAR banks' NPL ratio of

\footnotetext{
${ }^{12}$ The authorities are likely to opt for a property tax rate of around $1 / 4$ percent, half the level recommended by staff in the 2012 Article IV consultation.
} 
23.1 percent compares with 9.6 percent in Spain, even after a substantial amount of problem assets had already been transferred to NAMA. Substantial progress on enhancing banks' asset quality and restoring their profitability is needed to renew healthy lending in support of economic recovery and to contain the risk of additional capital needs developing.

\section{Enhancing asset quality}

26. To strengthen progress in resolving mortgage arrears, the authorities are making this a top priority for banks (MEFP I12). During 2012, frameworks to address asset quality issues through the CBI-led Mortgage Arrears Resolution Strategies (MARS) and personal insolvency reforms have been developed. To date, banks have granted various forms of forbearance to mortgage borrowers in payment difficulties, yet international experience indicates this

will not be a durable solution in a high Examples of Long-term Mortgage Resolution Options

proportion of cases. Banks are now rolling out a range of arrears resolution

The original mortgage is divided into a part that continues to be serviced in full and a warehoused part that falls due at a later time.

\begin{tabular}{ll}
\hline Split mortgage & $\begin{array}{l}\text { The original mortgage is divided into a part that continues to be serviced in full and } \\
\text { a warehoused part that falls due at a later time. }\end{array}$ \\
Mortgage-to-rent & $\begin{array}{l}\text { The lender or a housing authority acquires ownership of the property and rents it } \\
\text { back to the former borrower. }\end{array}$ \\
Trade down & $\begin{array}{l}\text { The mortgage borrower sells the property and purchases another at a lower price, } \\
\text { and is allowed to transfer negative equity to the new property. }\end{array}$ \\
Voluntary sale & $\begin{array}{l}\text { Mortgage borrower and lender agree to sell the property with an agreement } \\
\text { regarding the treatment of any shortfall to the loan amount. }\end{array}$
\end{tabular}
strategies — see text table — which have been piloted with a small set of borrowers. ${ }^{13}$ To facilitate stronger progress on implementation, the CBI will:

- Supervise banks' progress. The CBI will monitor each banks progress in durably resolving problem loans including against targets for reviewing new and existing arrears cases. It will publish aggregate key indicators on a quarterly basis, including re-default rates on restructured loans. The CBI is also analyzing a survey of households with mortgages, as well as Standardized Financial Statements of borrowers in arrears, and is planning to publish a first set of results in the first quarter of 2013.

- Ensure prudent provisioning for restructuring. The CBI will update, where necessary, its Impairment Provisioning and Disclosure Guidelines to ensure appropriate prudential treatment of loan modifications, including the warehoused tranche of a split mortgage.

- Facilitate more active engagement with borrowers. The Code of Conduct for Mortgage Arrears, which covers the regulation of engagement with borrowers in arrears, will be reviewed in early 2013 in light of longer-term loan modifications being rolled out and the new personal insolvency legislation. Staff considers that this review should also address provisions that, in the case of tracker mortgages, prevent moving to a different interest rate setting approach as part of a long-term loan modification.

\footnotetext{
${ }^{13}$ To help ensure debtors take well informed decisions, they can consult with an independent financial advisor when offered loan modifications under MARS through the newly established Mortgage Advisory Service.
} 
- Review progress by June 2013. The authorities will provide the EC/ECB/IMF with a review of progress in addressing residential mortgage arrears (proposed structural benchmark), which will be a key topic for the eleventh review.

27. The new personal insolvency framework will support the shift from short-term forbearance to durable solutions for household debt distress (MEFP [13). The personal insolvency legislation is expected to be adopted by parliament by year end, providing a set of out of court arrangements to facilitate debt resolution together with a shortening of the discharge period for bankruptcy to three years. ${ }^{14}$ Personal insolvency arrangements are most relevant for residential mortgages, and these will be mediated by a personal insolvency practitioner and subject to stringent eligibility criteria, approval by a qualified majority of creditors, and court approval. Before enactment, provisions for the licensing and monitoring of personal insolvency practitioners will be introduced, and staff has encouraged further amendments including in relation to the treatment of secured claims, valuation of assets, and the role of the courts. It would also be useful to clarify the treatment of contingent liabilities (e.g., guarantees) under the new regime.

28. Progress on the supporting infrastructure is essential to make the new personal insolvency framework operational in early 2013. A recently appointed Director Designate has been tasked with setting up an Insolvency Service to administer the new framework. Among its initial tasks, the information campaign for all parties concerned with the new framework will be particularly important. In the context of debt relief notices, it will issue guidelines for reasonable household expenditures for debtors, which may usefully inform the broader range of out-of-court arrangements.

29. Reform of the personal insolvency regime should be complemented by an effective repossessions process to facilitate durable loan resolution. The number of repossessions in Ireland is very low by international standards, and proceedings often take over a year, although recently banks have intensified collection efforts on investment properties by appointing rent receivers. The authorities will introduce legislation by end March 2013 to address issues identified by case law in repossessions (MEFP I[12, bullet 5). Given the substantial reforms of personal insolvency, staff urges a broader review of the repossession framework to identify measures to ensure it works efficiently in practice, taking into account the positive experience with expedited proceedings for repossessions available in the Commercial Court. Staff has also encouraged the development of vendor financing in the disposal of repossessed properties.

\section{The authorities will also address SME financing and resolution issues to help} restore their capacity to invest and create jobs (MEFP I14). The Temporary Partial Credit Guarantee Scheme, of up to $€ 150$ million annually, was recently launched to facilitate lending to eligible SMEs. But many SMEs need to resolve their debt burdens - often related to real

\footnotetext{
${ }^{14}$ The personal insolvency reform is described in Box 2 of the sixth review.
} 
estate-before they can gain access to new financing. Accordingly, the authorities will monitor closely banks' implementation of arrears resolution strategies for SMEs, facilitating a move away from short-term forbearance to more durable restructuring solutions; resolution of SME arrears will be a focus of the next review. In addition, by end year the authorities will prepare legislative amendments to improve the efficiency of the corporate insolvency framework for SMEs, by designating of the Circuit Courts as competent for the examinership of companies within the EU small-company thresholds. The potential to further reduce costs and achieve efficiency gains through out-of-court solutions will be reviewed based on experience with the Insolvency Service.

\section{Improving profitability}

31. With losses gradually eroding the PCAR banks' still-high capital ratios and undermining lending capacity, a range of initiatives are underway to restore bank profitability (MEFP I15-16). Efforts to reduce loan arrears aim to enhance debt service performance in the medium term but could necessitate additional loss recognition in the near term. In addition, important efforts are in train to reduce some of the drags on banks' preprovision net revenue (PPNR):

- Excessive operating costs, which banks are moving to lower in line with their substantially reduced balance sheets and revenue streams through staff and branch network cuts (Box 4). PTSB, in particular, has reorganized into three business units, which the authorities will monitor against quarterly benchmarks; and

- High guarantee fees, are to be addressed through an orderly withdrawal of the Eligible Liability Guarantee (ELG) scheme guided by a roadmap being finalized by an inter-agency working group by year end. ${ }^{15}$

\section{These efforts are important, yet progress will be constrained if funding costs} remain high. One difficult profitability issue is banks' large portfolios of "tracker" mortgages, which, by being indexed to ECB policy rates, impose a negative cost of carry in the current environment of low policy rates relative to banks' funding costs. Banks continue to face high funding costs even after their recapitalization, as seen in deposit rates about

\footnotetext{
${ }^{15}$ Withdrawing the ELG will reduce fiscal revenues by 0.4 percentage points of GDP between 2012 and 2013.
} 
1 percent above the euro area average. While their Eurosystem borrowing is large, current refinancing arrangements do not allow banks scope to lower deposit rates to levels more typical for the euro area. Indeed, banks pay high premia on the limited available market funding to reduce their ECB borrowing, and this funding cost drain on profitability persists in undermining lending capacity and financial stability. Breaking bank-sovereign linkages is needed to expand alternative market funding options and allow funding costs to decline.

\section{Box 4. Reducing PCAR Banks' Operating Costs}

Cost structures for the PCAR banks are challenging. The contraction of gross revenuesbefore provisioning expenses - has raised their average cost to income ratio to over double that of comparably sized well performing EU peers. The gross revenue decline reflects drags on net interest income and other components of PPNR, and a contraction of total assets due to deleveraging and the divestiture of performing assets. Costs have been trending up since 2010 due to extraordinary consultancy fees and outlays associated with restructuring.

Restructuring will help reduce operation costs. From an FTE level of about 30,000 at end 2011, the plan is to reduce staffing by approximately 20 percent by end 2015 through a mix of attrition and voluntary severance schemes. In addition, the three PCAR banks together plan to shed 61 branches, or 7 percent of their current network. However, the reduction in total the staff count per branch, from 35 FTE to 29, may be still insufficient and further operational restructuring needed going forward.

\section{Other financial sector measures}

33. The framework to restore the viability and solvency of the credit union sector is near finalization (MEFP I17). The Credit Union Bill published on September 28 draws on the recommendations of the March 2012 report of the Commission on Credit Unions to strengthen the regulatory framework for credit unions, including effective governance standards and prudential requirements (structural benchmark). ${ }^{16}$ It also provides for a time-limited restructuring process to be led by a Restructuring Board (ReBo) which will work with credit unions to bring forward restructuring proposals that are then subject to CBI regulatory approval. ${ }^{17}$ The authorities are refining the Bill, which will include clarifying that any public resources not reimbursed by restructured institutions will be recouped in full by means of a sector-wide levy. The authorities intend to establish a $€ 250$ million Credit Union Fund by end 2012 to facilitate the restructuring beginning in 2013. Adjustors to the performance criterion on the exchequer primary balance and the indicative target on the stock of central government net debt are proposed to accommodate this up-front expense. Staff encouraged progress in the analytical work to support the work of ReBo, including to refine estimates of the total restructuring cost, previously put at $€^{1} / 2$ to 1 billion.

\footnotetext{
${ }^{16}$ The Registrar of Credit Unions has linked sound financial reporting, especially on impaired assets, to the fitness and probity tests to be established under the new legislation for credit union management.

${ }^{17}$ Members of the ReBo have already been appointed and will begin communication and analytical work in preparation for the legislation becoming effective, http://www.finance.gov.ie/viewdoc.asp?DocID=7354.
} 
34. Strengthening of financial supervision and regulation continues. Key measures include:

- Reviewing banks' financial performance relative to PCAR 2011 (MEFP I18). This review will cover a range of indicators including credit quality, loans loss provisions, losses from deleveraging, and pre-provision net revenue. It will serve as a bridge to the next set of stress tests to be aligned with the timing of the next EBA exercise in 2013.

- Supervisory and enforcement powers (MEFP 919). The Central Bank (Supervision and Enforcement) Bill will enhance key powers of the CBI to investigate, issue orders, and enforce corrective actions. Parliamentary discussions are ongoing and staff supports the authorities' determination to move the Bill forward expeditiously.

- External standards assessments (MEFP 『19). The CBI is conducting self-assessment of compliance with the Basel Core Principles (BCP) for Effective Banking Supervision, and will request an external assessment by end March 2013 (proposed structural benchmark), with the aim to be completed by end 2013. A similar approach will be taken to the International Organization of Securities Commissions' Objectives and Principles of Securities Regulation.

- Resolution fund levy (MEFP I19). Regulations governing its first year were issued on September 29 (structural benchmark), with the levy to be assessed on all credit institutions using Pillar 1 capital requirements as the base, with rates varying across domestic, foreign, and IFSC banks. The contribution rate for credit unions is assessed on total assets. The regulation will be reviewed in light of developments in EU policy, and the authorities confirmed their intention to recoup public resources provided to the Resolution Fund by the Minister for Finance

- Credit register (MEFP I20). The Credit Reporting Bill was published in September 2012. The authorities aim to have the Register operational by end 2013, which is important to facilitate sound lending decisions and aid financial supervision.

\section{Enhancing Growth and Job Creation}

35. The authorities continue to focus on enhancing growth and job creation. Two sources of investment commencing in 2013 are being developed (MEFP 121). Projects totaling 0.9 percent of GDP in education, transport, health care, and justice will be carried out through public-private partnerships with funds from the European Investment Bank, the National Pension Reserve Fund, and private investors. In addition, the authorities continue to prepare selected state assets for disposal, with up to half of proceeds to be reinvested in job-rich projects. The authorities are also continuing the implement the Action Plan for Jobs (MEFP I22), with the Third Progress Report showing almost 90 percent of the plan completed by the end of September. Going forward, the authorities plan to focus on promoting access to finance and investment by SMEs, supporting indigenous start ups and assisting indigenous businesses to grow, and developing and deepening the impact of FDI. 
36. To help reduce unemployment over time, the authorities are stepping up a range of reforms (MEFP $[23)$. In particular the authorities are advancing:

- Engagement with the long-term unemployed. In October, the authorities launched a new one-stop shop unemployment support service, operating on the basis that welfare payments are contingent upon participation in activation programs and active job search. Importantly, the authorities are taking steps to enhance engagement with the long-term unemployed through these one-stop shops, the Local Employment Services Network, and other schemes. Involvement of the private sector in providing employment services is expected to be operational by end-2013, and it is important to stay on schedule given the high share of long-term unemployed and shortages of qualified case workers.

- Further education reform. In October, the authorities published new legislation to reform the organization of further education, and by the end of the year they will publish legislation to establish a central institution that will coordinate and fund training and further education programs. Timely implementation of these reforms is needed to ensure courses are in line with labor market needs to facilitate cross-sectoral mobility of unemployed persons, including those with lower initial educational attainment.

- Housing assistance reform. Recognizing employment disincentives that may arise from the current rent supplement, the authorities are establishing a new Housing Assistance Payment, where the amount of individual contribution will depend on the level of income and not the employment status, hence improving incentives to take up employment. Necessary legislative amendments will be made in the first half of 2013, and the program will be piloted in the second half of the year, to be fully operational as of January 2014.

\section{Program Modalities}

37. Program monitoring has been updated until September 2013 (MEFP tables 1-3):

- Quantitative performance criteria are proposed for end-March 2013 (MEFP Table 2 ). The performance criterion for the Exchequer primary balance is unchanged for end-December 2012 and the previously set end-March 2013 indicative target is being converted into a performance criterion. Indicative targets for end-September 2013 are proposed for the Exchequer primary balance and for net central government debt. The TMU was modified to clarify that the definition of the Exchequer primary balance for programme monitoring purpose will exclude all payments related to the IBRC Promissory Notes from January 2013 onwards. A set of adjustors to the floor on the Exchequer primary balance is also added to allow for Exchequer outlays on credit union restructuring (capped at $€ 250$ million) and for receipts from the disposal of state assets.

- New structural benchmarks are proposed: request for an external BCP assessment (end March 2013), and review of progress in addressing mortgage arrears (end June 2013). 


\section{The authorities' financing strategy is firmly aimed at deepening market access} and facilitating an exit from official financial support. Building on their return to the bond market in July and placement of amortizing bonds in August, the authorities have continued their regular Treasury bill issues. To consolidate this market access, the authorities are engaging actively to broaden their investor base and will seek to increasingly move to regular bond issuance (MEFP I24). Accordingly, the authorities have expanded their funding plan for 2013 from $€ 4$ billion at the last review to about $€ 10 \frac{1}{2}$ billion, including long-term bond issuance and retail funding. Their goal is to end 2013 with a cash buffer covering about one year of financing needs to support market confidence.

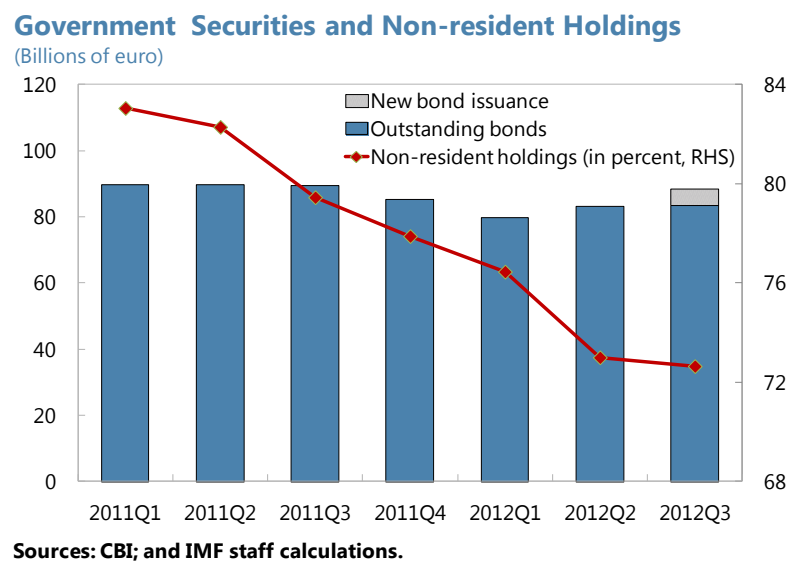

39. At the same time, there are significant risks to retaining market access in coming years. Prospective funding needs require Ireland to place sizable amounts on bond markets each year, and this will required substantial international participation; nonresidents hold 73 percent of outstanding securities. Ireland has recently enjoyed support from investors that conduct their own credit analysis. Going forward, however, a broader investor base will be needed, including more ratingssensitive fund managers. Although one agency recently removed its negative outlook, Ireland's credit rating remains at the threshold of speculative grade as ratings agencies see a number of risks (Box 5) which are broadly consistent with the risks to growth and debt sustainability risks set out in Section III.

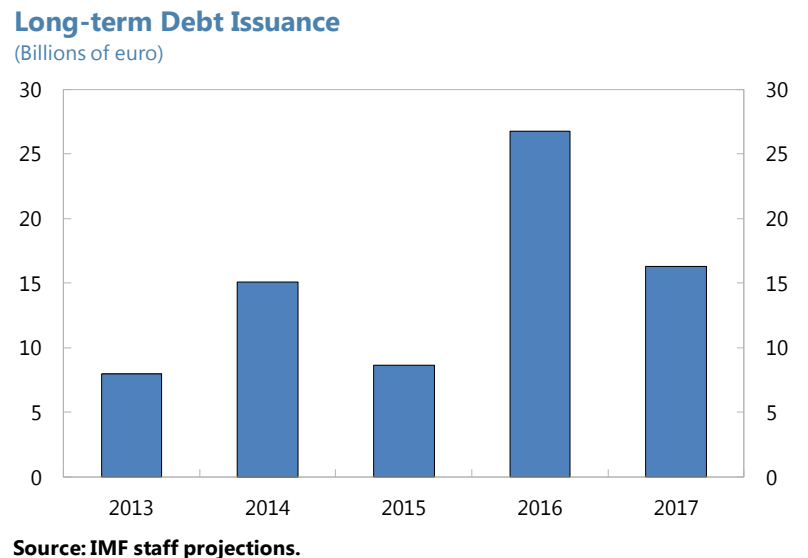

40. Although subject to significant risks, the exceptional access criteria continue to be met:

- Under the baseline macroeconomic framework, debt sustainability is expected to be maintained over the medium term, although subject to significant risks if growth does not strengthen or if further contingent liabilities materialize. Crucially, this relies on ongoing strong program commitment and implementation, along with European policymakers delivering on their commitments in order to reduce strains in countries facing stress and ensure financial stability of the euro area. As debt sustainability is not assured with a high probability, the program continues to be justified on the basis of systemic international spillover risks given euro area fragility. 


\section{Box 5. Ireland in the Eyes of the Credit Rating Agencies}

Ireland's sovereign credit ratings have straddled the investment and speculative grades since 2011. Fitch Ratings and S\&P maintain long-term sovereign ratings in the low investment grade ('BBB+'), while Moody's rates Ireland at the top of the speculative grade ('Ba1'). Moody's and S\&P attach negative outlooks to these ratings, but Fitch's outlook was revised to stable in mid-November.

The recent compression of Ireland's sovereign bond spreads has not been associated with any credit rating upgrades. During 2010-11, ratings downgrades and Irish bond spread widening broadly moved together. But there have been no upgrades since spreads began narrowing from mid-2011, with ratings agencies appearing to take a more cautious approach regarding announcements of European policy actions.

The rating agencies link Ireland's ratings to deep-seated fiscal vulnerabilities along with risks to growth, cushioned somewhat by structural factors:

Public debt: high public debt and fiscal deficits are a major concern for all three agencies, mitigated by political support for fiscal consolidation and the strong budgetary track record;

Financial sector: two agencies point to rising NPLs and the low foreclosure rate as sources of risk, while taking comfort in the capitalization of the banks;

Growth: economic stagnation is seen as a risk due to the debt overhang, fiscal consolidation, limited private sector credit associated with deleveraging, and weak external demand.

Financing gaps: Moody's is concerned that financing gaps could emerge after the end of the current program, necessitating a second EU-IMF supported program.

Two of the agencies continue to indicate a bias toward ratings downgrades, with spillovers from Europe as a key risk factor. Concerns include deterioration in the economic outlook, including from a deepening of the recession and deleveraging across Europe, which could occur if there is a delay or reversal in euro area banking and fiscal union.

The potential for rating upgrades is linked to improvements in debt dynamics, including through growth recovery, and European support. Removing the negative outlook on current ratings, or actual upgrades, could occur if the likelihood of euro area assistance for bank support costs increases, and if medium-term growth prospects become more favorable, including through moderation of the euro area crisis. 
- In view of Ireland's strong program performance and commitments, its recently regained market access, and the June 29 summit statement by euro area leaders to improve the sustainability of Ireland's program, there are adequate prospects to retain and expand access to private capital markets before Fund repurchases begin in July 2015. There is however, a risk of inadequate progress toward stronger European support, which would weaken the assurances of adequate and durable market access given Ireland's public debt and financial sector vulnerabilities.

- More broadly, the policy program of Ireland is sound and adjustment is being delivered, providing sufficient prospects for program success. More effective policy action, and delivery on commitments at the European level is needed to strengthen prospects for success.

\section{StAFF Appraisal}

41. The Irish authorities' have maintained consistent delivery on their program.

Once more the quantitative targets for the review were met and all structural benchmarks have been observed. Fiscal outturns for 2012 remain on track and financial sector and structural reforms are progressing. Benefitting significantly from European pledges of further strengthened support, this performance has contributed to a notable decline in Irish sovereign bond yields and to the renewal of sovereign market access.

\section{Near-term growth prospects are weak, however, and the baseline outlook for} gradual recovery over the medium-term is subject to significant risks. The outlook for net exports - the sole engine of growth - has weakened with lower trading partner growth prospects. Domestic demand is still expected to decline next year, though at a slower pace, before beginning to revive in 2014 as needed to underpin job creation. However, this demand revival faces hurdles including the debt overhangs of the public and private sectors and the bank-sovereign loop that impairs bank access to market funding. Uncertainties also arise regarding the timing of benefits from financial sector reforms and the extent of drag from fiscal consolidation. These risks around medium-term growth prospects are a key source of fragility in Ireland's debt sustainability, in part because prolonged low growth could result in new capital needs in the financial sector.

\section{The authorities should complete their medium-term fiscal plans by clarifying the} remaining measures needed to underpin the consolidation in the outer years. Considering the need to protect the recovery, the updated MTFS continues to provide for a phased path toward a deficit below 3 percent of GDP in 2015 and a balanced composition of adjustment between expenditures and revenues. If growth is weaker than projected in 2013, any significant additional adjustment efforts should be deferred to 2015 when the consolidation planned is smaller. To secure achievement of the medium-term deficit goal, effective implementation of structural reforms to generate savings while protecting public services will be critical, taking into account the high level of public sector wages relative to private sector and international comparators. Progress on institutional fiscal reforms, including the Fiscal 
Responsibility Bill underpinning the independent fiscal council, the multi-annual expenditure ceilings, and increased transparency, will support sound fiscal policy and debt reduction over the long term.

\section{Budget 2013 needs to deliver the targeted consolidation through a package of} measures that are durable, equitable, and as growth-friendly as possible. It is welcome that the authorities are considering a raft of high-quality measures to achieve the total effort of 2.1 percent of GDP, including better targeting of social benefits and subsidies, public sector pay bill reductions through allowances and working hours, as well as revenue base broadening, most notably through the introduction of a property tax. It would also be appropriate for measures to begin to contain the fiscal implication of ageing, including on the revenue side. The multi-annual expenditure ceilings should continue to be a key anchor for the fiscal consolidation, especially through durable savings measures in the health sector in 2013.

\section{Financial sector reform implementation needs to be galvanized to create} conditions conducive to sound bank lending in support of economic recovery. Given the still-fragile state of the banks, with rising loan impairments and high funding costs contributing to operational losses, the immediate priorities are to arrest the deterioration in asset quality and to advance operational restructuring. Important preparations have been made through developing banks' strategies and capacity for arrears resolution but implementation of long-term solutions has lagged. Close supervision of the adequacy of banks' efforts is therefore important, together with ensuring prudent provisioning for loan modifications. The reforms of personal insolvency will provide new opportunities for out-of-court resolution of household debt distress, and it is essential that these reforms be complemented by a well functioning repossession process to maintain debt service discipline through the workout process. Continued efforts to lower funding costs, including by orderly withdrawal of the ELG scheme and steps to reduce operational costs are essential, yet breaking the bank-sovereign loop would have the greatest benefit for strengthening profitability and lending capacity.

\section{Reducing unacceptably high unemployment requires a range of efforts. A} recovery in economic growth is a prerequisite for job creation, but it is also crucial to ensure that job seekers remain in the labor force and acquire useful skills. The rollout of integrated employment services is therefore key, especially plans to increase engagement with the long-term unemployed, who are most at risk. Strong and timely implementation is needed on involving the private sector in providing employment services, reforming further education to ensure that training is in line with market needs, and establishing the Housing Assistance Payment to reduce employment disincentives from the current structure of housing supports.

\section{Continued strong policy implementation is essential, yet timely exit from official} support cannot be assured without forceful delivery of European pledges. Ireland is on track to deliver the full fiscal consolidation, bank recapitalization and deleveraging, and structural reforms envisaged under the program. However, weak external demand and internal hurdles have slowed growth and also cast uncertainties around medium-term recovery prospects. The resulting risks to debt dynamics are magnified by the sensitivity of financial 
sector health to growth trends in view of high private debt burdens. In this context, market doubts about debt sustainability could easily reemerge, undermining the availability of the substantial market financing needed and resulting in prolonged dependence on official support. The most definitive way to forestall such a scenario would be through decisive direct bank recapitalization by the ESM, which would reduce public debt directly and insulate the sovereign from potential contingent liabilities from the banking sector. The risk of such liabilities arising would be greatly reduced, as breaking the bank-sovereign loop and debt overhangs in this manner would improve prospects for domestic demand recovery, including by enhancing bank funding conditions. The way forward is clear.

\section{Staff supports the authorities' request for completion of the eighth review.}




\section{Figure 1. Ireland: Real Sector and Inflation Indicators}

Net exports remained the main contributor to growth in the first half of 2012...

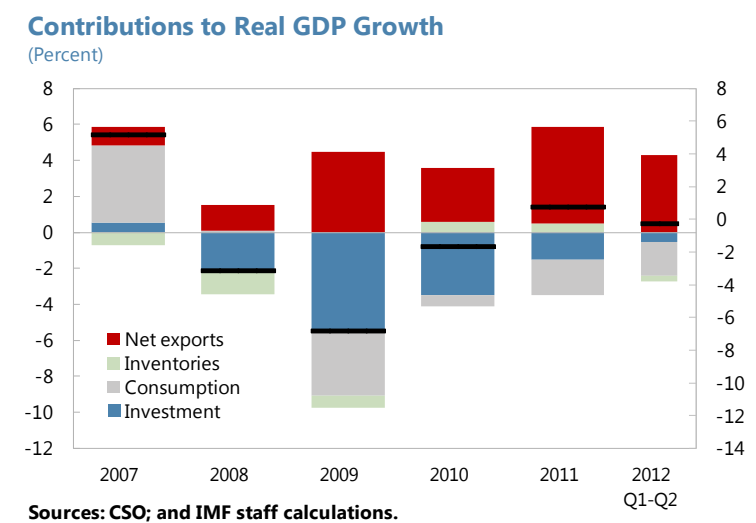

Industrial production continued to rise until August, though the recent decline in export orders may signal worsening prospects for the rest of the year.

Export Indicators and Industrial Production

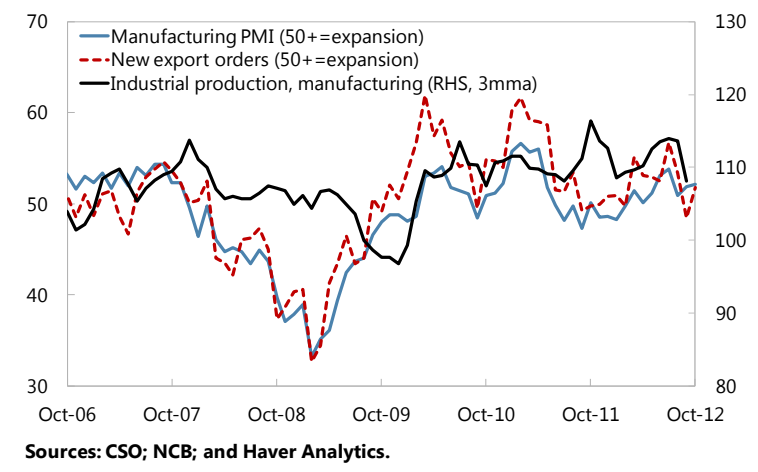

Inflation averaged 2 percent in the first three quarters, mostly due to increases in energy and administered prices.

Contribution to Annual HICP Inflation

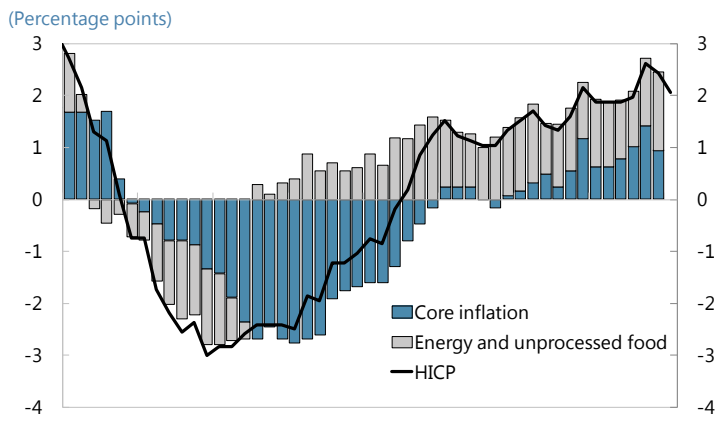

Oct-08 Apr-09 Oct-09 Apr-10 Oct-10 Apr-11 Oct-11 Apr-12 Oct-12

Sources: CSO; and IMF staff calculations.
.... while retail trade volumes edged up 11/4 percent $y / y$ in July-October, but consumer sentiment declined.

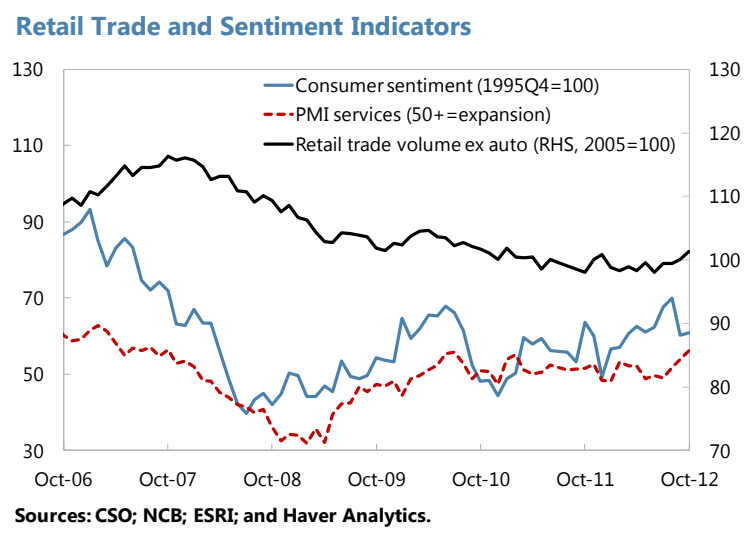

The current account remained in surplus in the first half of 2012 as strong net exports outweighed income outflows.

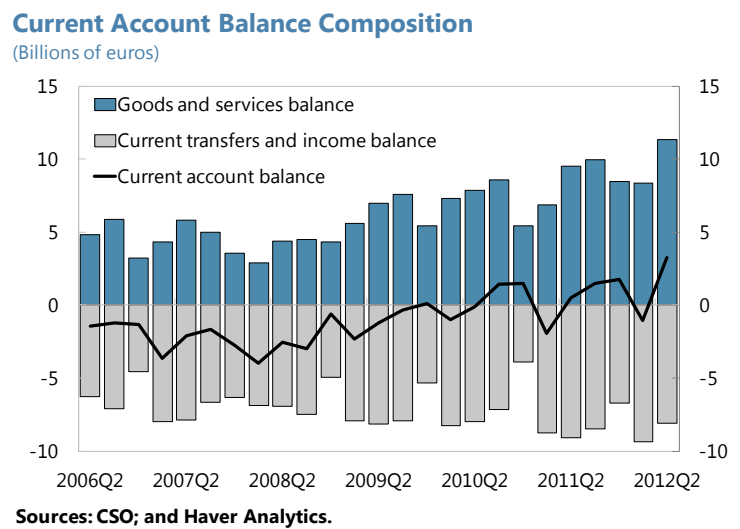

Unemployment remained high, with over 60 percent long term and youth unemployment rising to 34 percent.

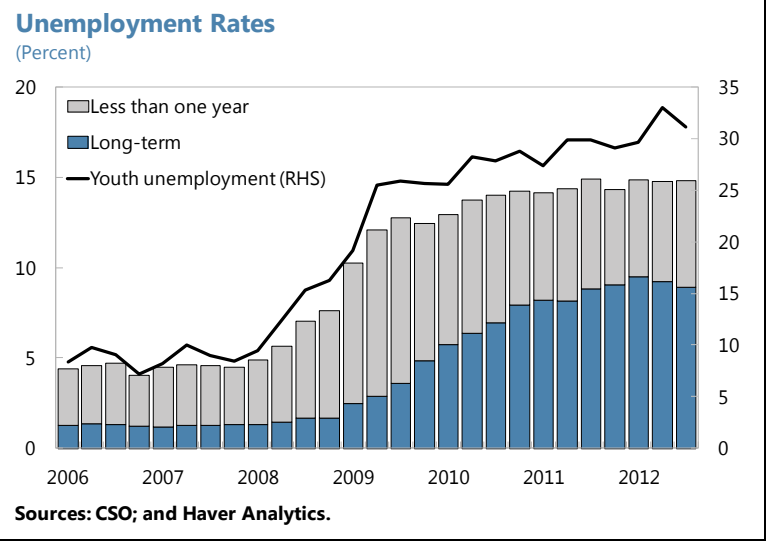


Figure 2. Ireland: Household Finance and Housing Developments, 2001-12

Household savings remain elevated, with half of savings devoted to debt reduction...

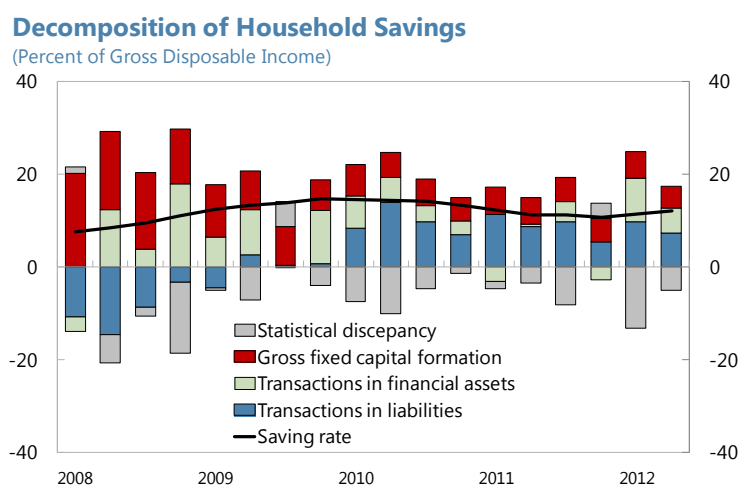

Sources: CBI; ECB; Haver Analytics; and IMF staff calculations.

Declining incomes and rising unemployment also led to rising mortgage arrears...

\section{Mortgages in Arrears}

(Percent of total mortgage value)

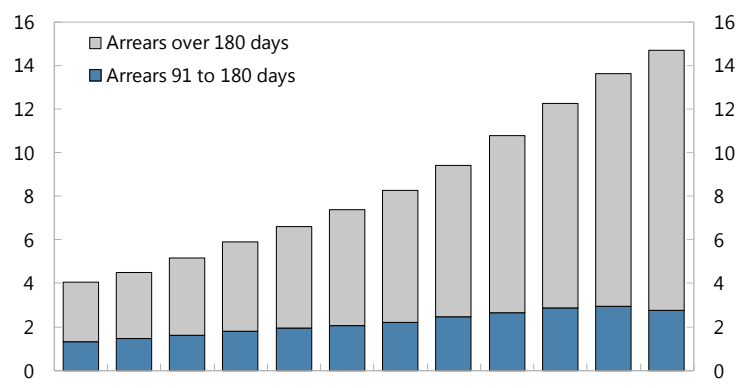

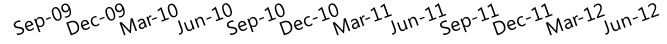

Source: Central Bank of Ireland.

... which has brought rental yields and the house price-toincome ratio toward more normal levels...

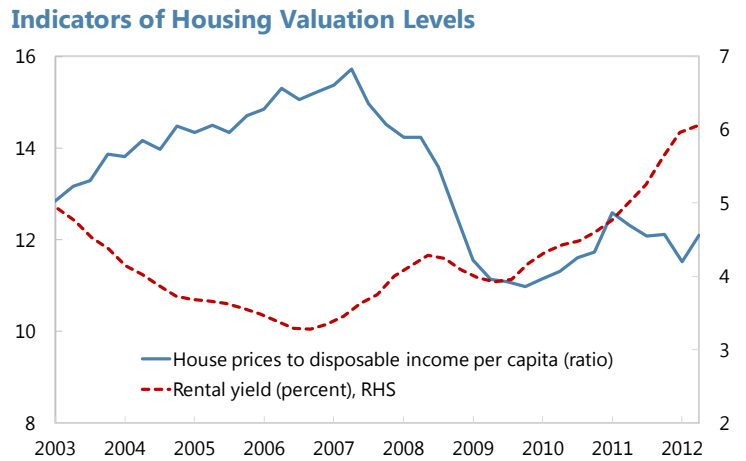

Sources: CSO; ESRI; NTMA; and Haver Analytics. ...but, owing to declining incomes, household debt burdens have started to decline only recently.

Household Debt and Interest Payments

(Percent of disposable income)

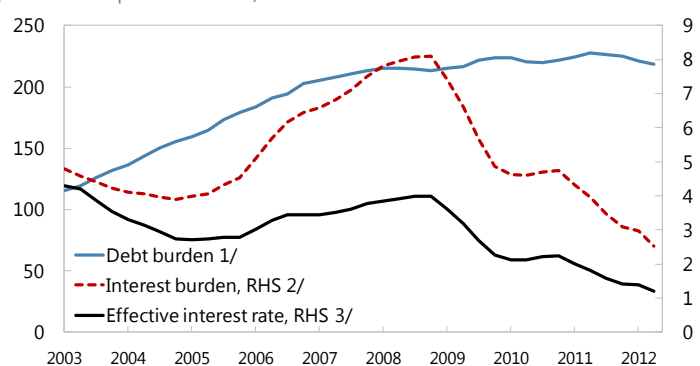
Sources: CBI; Haver Analytics; and IMF staff calculations.

$1 /$ Total household liabilities in percent of four-quarter gross disposable income.

2/ Four quarter interest payments in percent of four-quarter gross disposable income.

3 / Four quarter interest payments in percent of previous quarter's total household liabilities.

...even as the decline in property prices has slowed after prices halved from their peak levels...

Residential Property Prices

(2005M1=100)

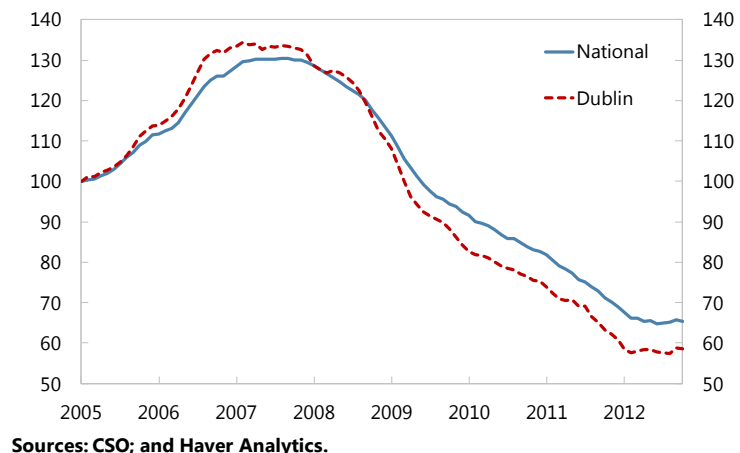

...but turnover in the market has remained subdued, in part due to dormant new lending.

Loans for House Purchases

(Billions of euros)

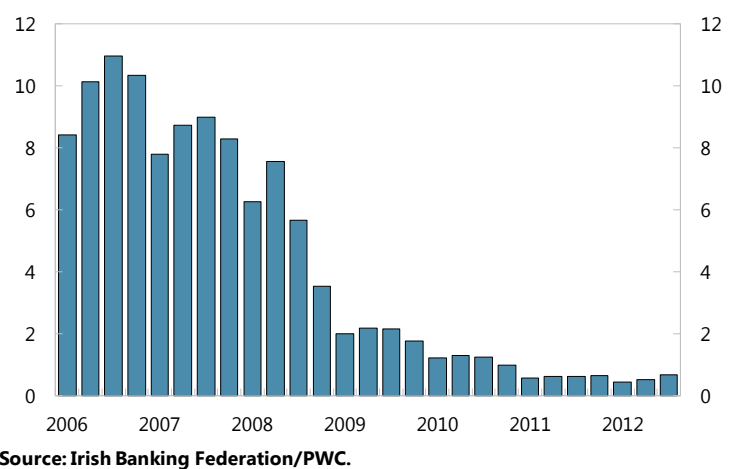


Figure 3. Ireland: Credit Developments, 2006-12

The level of private sector deposits has stabilized...

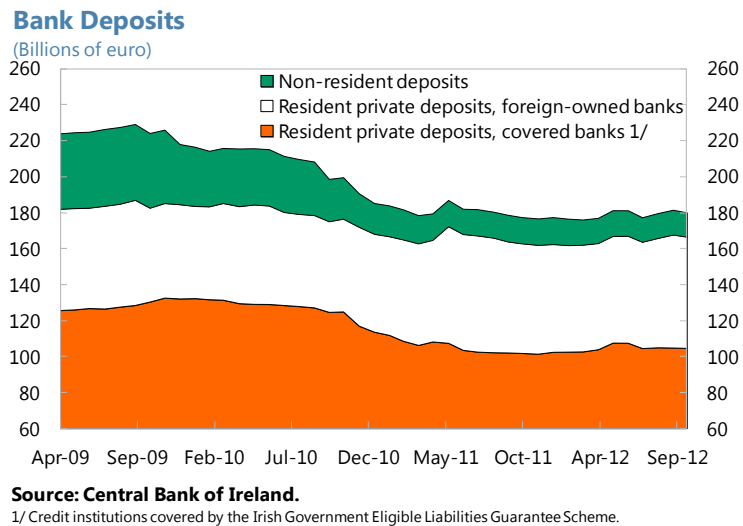

Total SME lending remains low...

Outstanding SME Credit 1/

(Billions of euros)

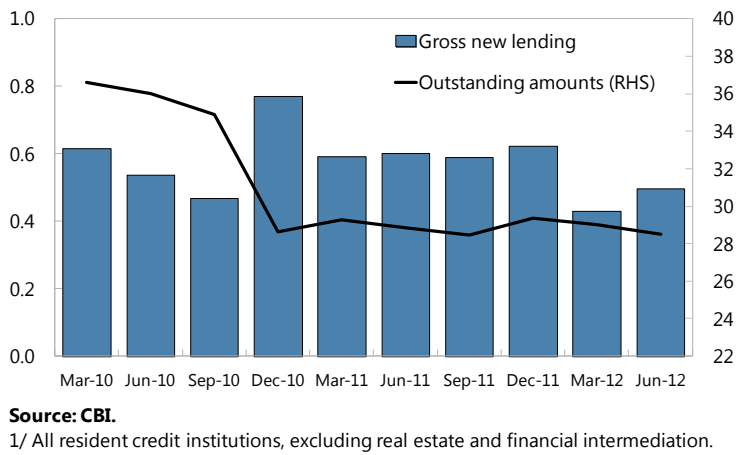

Credit standards are broadly stable, with some tightening in consumer lending in recent quarters...

Changes in Credit Standards

(2006Q1=100, + = tightening)

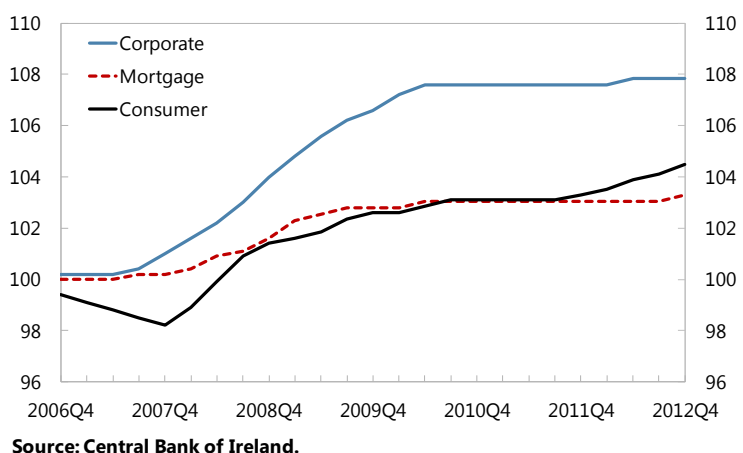

...but credit to households and corporations continues to contract as repayments exceed lending.

Loans Outstanding to Irish Residents

(Year-on-year percentage change)

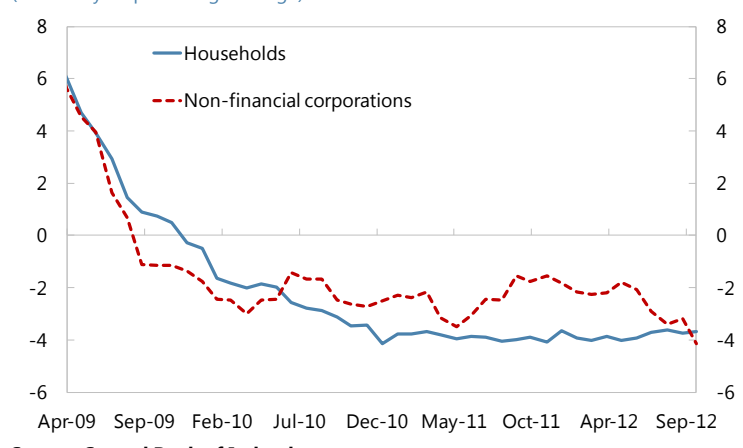

Source: Central Bank of Ireland.

...with no SME sectors recording a significant rise in credit outstanding.

Outstanding SME Credit by Sector 1/

(2010Q1=100

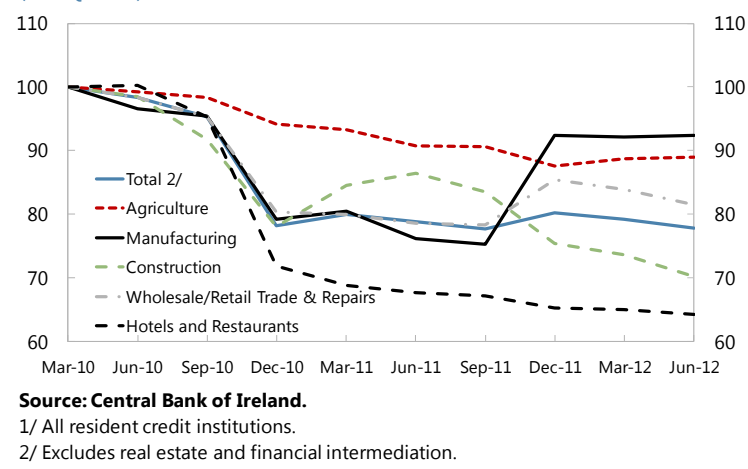

...but demand for mortgages, and more tentatively credit demand from the corporate sector, appears to be rising.

Changes in Credit Demand (2006Q1=100)

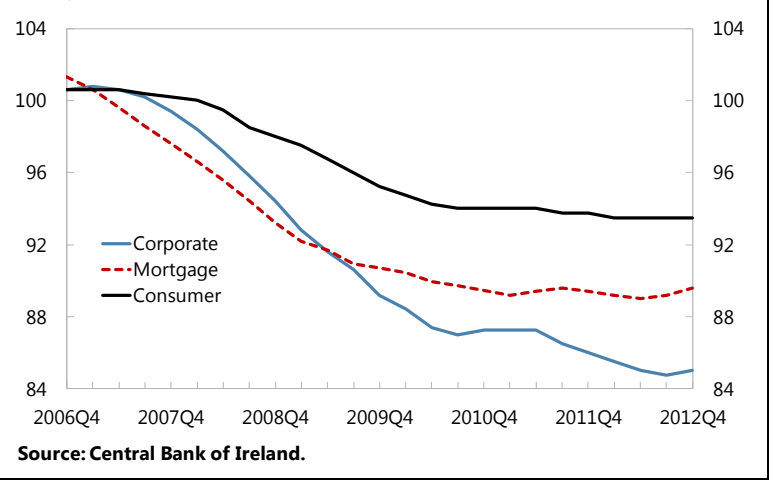


Figure 4. Ireland: Competitiveness Indicators

Competitiveness continues to improve, helped by the nominal depreciation of the euro...

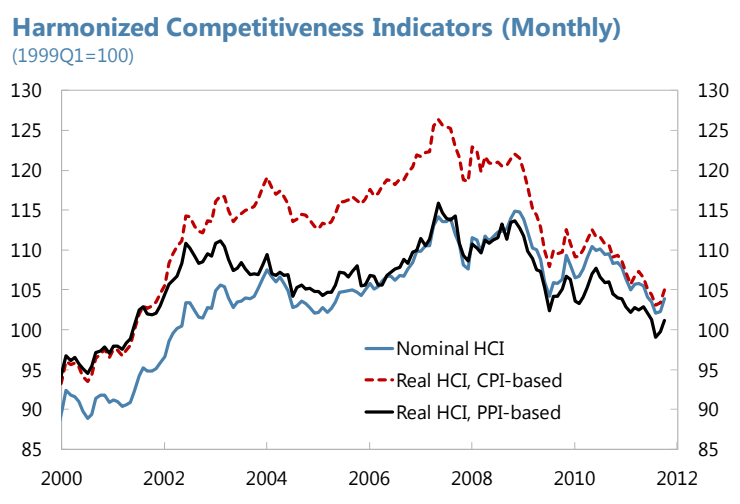

Source: CBI; and Haver Analytics.

...though part of the decline reflects a shift to higher valueadded sectors.

Real Effective Exchange Rates on a ULC Basis (2008Q1=100)

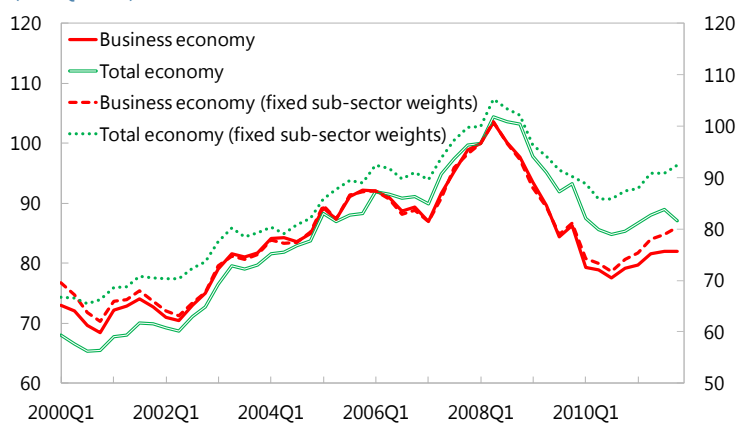

Source: Bruegel.

.... while labor productivity has risen faster than in the euro area in recent years...

Real Labor Productivity

$(2005=100,5$ A )

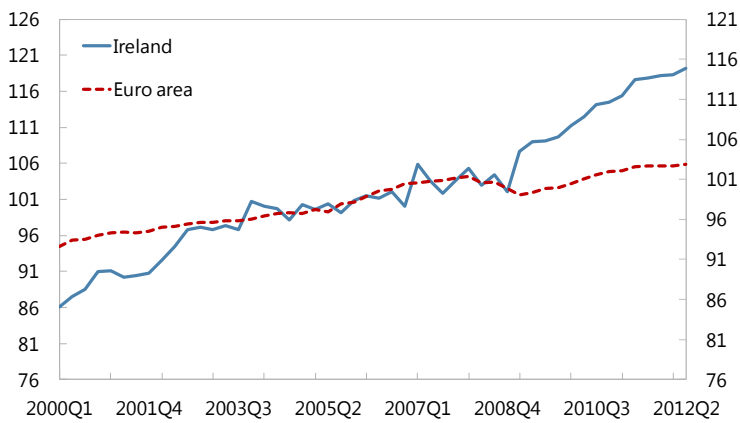

Source: Eurostat.
Harmonized Competitiveness Indicators (Quarterly)

(1999Q1=100

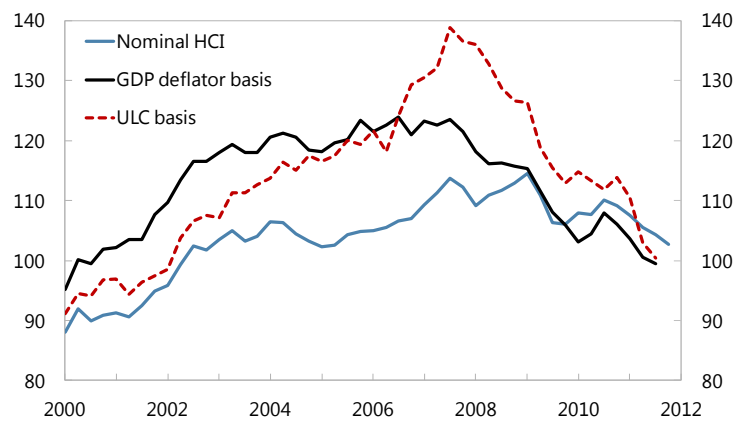

Source: CBI; and Haver Analytics.

Private wages have declined only modestly, but significantly relative to the euro area..

Hourly Labor Costs in Manufacturing

(2006=100; 4-quarter moving average)

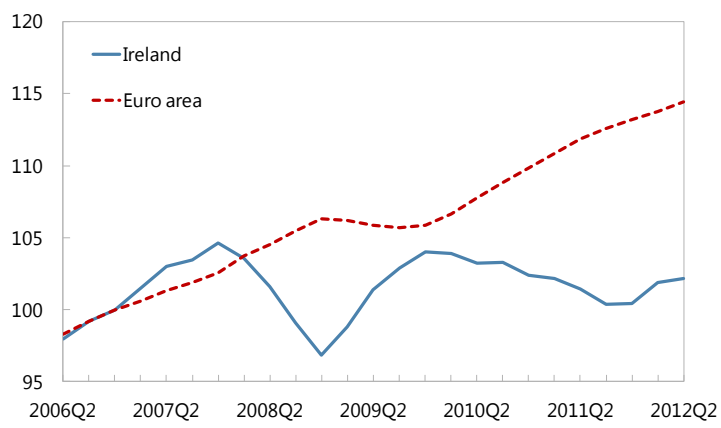

Sources: CSO; Eurostat; Haver Analytics; and IMF staff calculations.

As yet, competitiveness improvements have not been reflected in rising market shares.

Export Shares

(Percent of world non-oil imports)

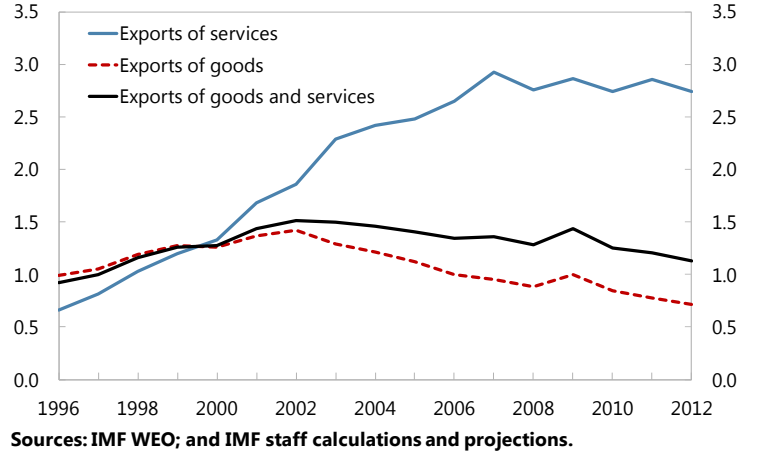


Figure 5. Ireland: Selected Trends in General Government Finances

Two-fifths of the 11 percent of GDP primary balance improvement (2010-15) will be achieved by end-2012.

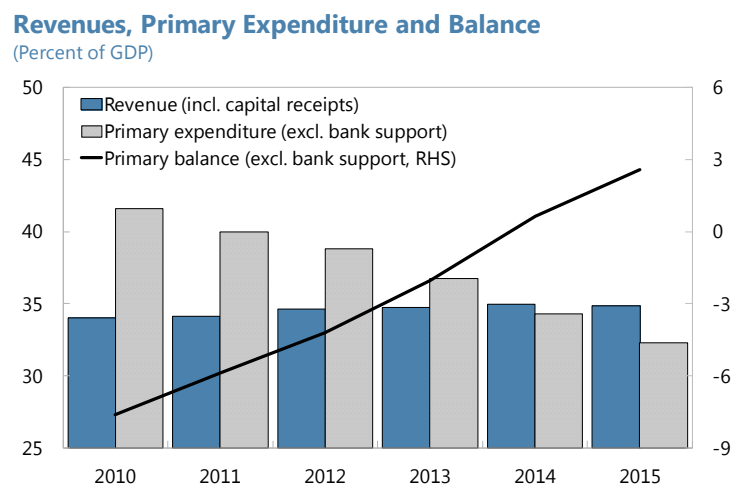

Sources: Department of Finance; and IMF staff estimates.

Given the weaker recovery in nominal domestic demand, tax measures will not raise revenues as a share of GDP.

Revenue Composition

(Percent of GDP)

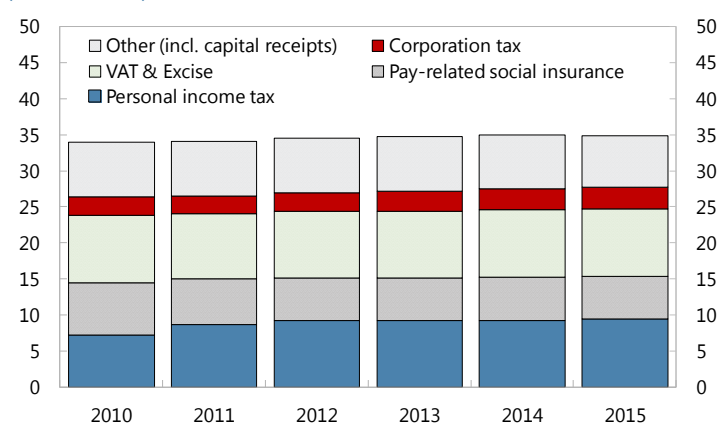

Sources: Department of Finance; and IMF staff estimates.

A 3 percent of GDP overall deficit, and 21/2 percent of GDP primary surplus, are targeted for 2015.

Headline, Primary and Structural Balance 1/

(Percent of GDP)

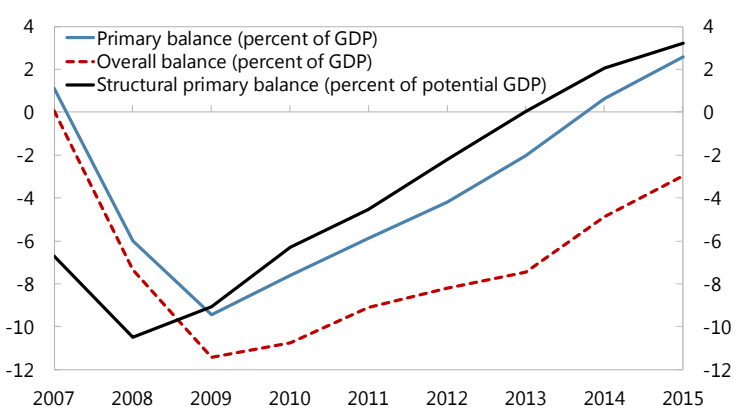

Sources: Department of Finance; and IMF staff estimates.

1/ Excluding bank support.
Fiscal consolidation is phased in a front-loaded manner and is expenditure-led.

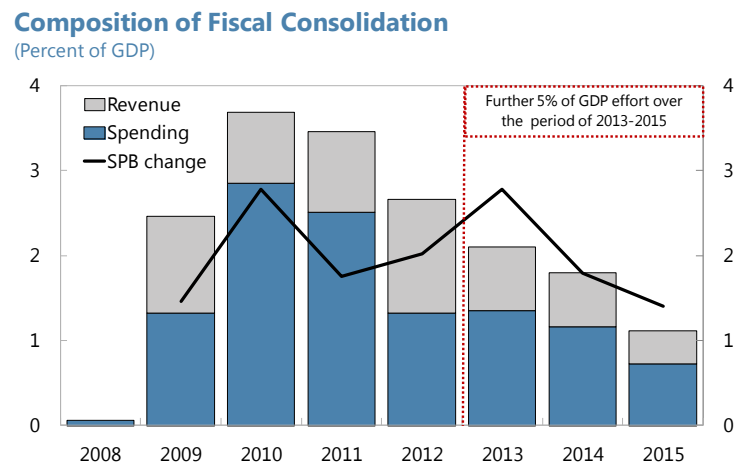

Source: IMF staff estimates.

SPB denotes structural primary balance ratio.

Primary expenditures will fall by 10 percent of GDP, reflecting evenly spread durable savings.

Primary Expenditure Components

(Percent of GDP)

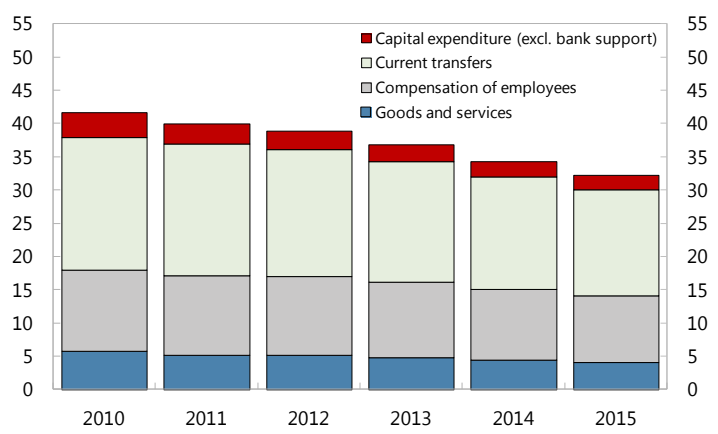

Sources: Department of Finance; and IMF staff estimates.

It will take time to unwind the increase in net debt, three-fifths of which arose from bank support costs.

Sources of Increase in Net Debt-to-GDP Ratio (Percent of GDP)

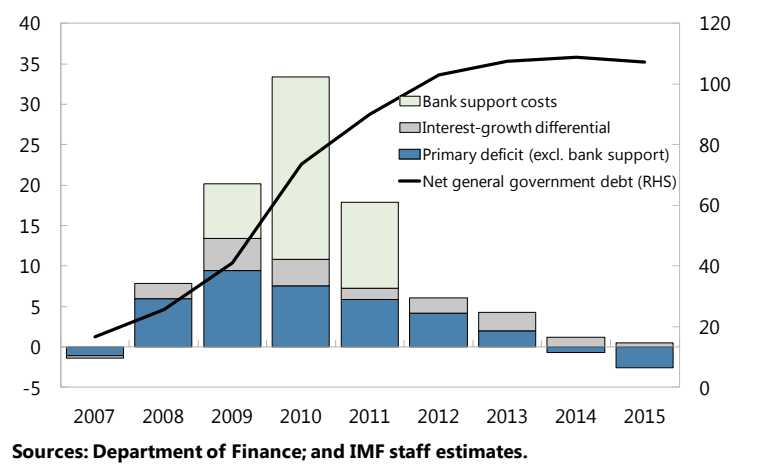


Table 1. Ireland: Selected Economic Indicators, 2008-13

(Annual percentage change unless indicated otherwise)

\begin{tabular}{|c|c|c|c|c|c|c|}
\hline & \multirow[t]{2}{*}{2008} & \multirow[t]{2}{*}{2009} & \multirow[t]{2}{*}{2010} & \multirow[t]{2}{*}{2011} & 2012 & 2013 \\
\hline & & & & & \multicolumn{2}{|c|}{ Proj } \\
\hline \multicolumn{7}{|l|}{ National accounts (constant prices) } \\
\hline Real GDP & -2.1 & -5.5 & -0.8 & 1.4 & 0.4 & 1.1 \\
\hline Domestic demand & -3.7 & -11.0 & -4.2 & -3.7 & -2.9 & -0.9 \\
\hline Private consumption & -0.1 & -5.4 & 1.0 & -2.4 & -2.1 & -0.5 \\
\hline Public consumption & 0.6 & -4.4 & -6.5 & -4.3 & -4.0 & -2.0 \\
\hline Gross fixed investment & -10.0 & -27.6 & -22.6 & -12.6 & -4.0 & -1.5 \\
\hline Net exports $1 /$ & 1.4 & 4.5 & 3.0 & 5.4 & 2.7 & 1.8 \\
\hline Exports of goods and services & -1.1 & -3.8 & 6.2 & 5.1 & 2.8 & 3.2 \\
\hline Imports of goods and services & -3.0 & -9.7 & 3.6 & -0.3 & 0.3 & 2.1 \\
\hline Real GNP & -1.8 & -8.1 & 0.9 & -2.5 & -0.5 & 0.3 \\
\hline Gross national saving (in percent of GDP) & 16.3 & 13.5 & 13.1 & 11.3 & 11.7 & 12.5 \\
\hline Private & 18.2 & 21.2 & 20.4 & 17.7 & 18.2 & 18.3 \\
\hline Public 2/ & -1.9 & -7.7 & -7.2 & -6.4 & -6.5 & -5.8 \\
\hline Gross investment (in percent of GDP) & 22.0 & 15.9 & 12.0 & 10.1 & 9.9 & 9.8 \\
\hline Private & 16.5 & 12.1 & 8.5 & 7.5 & 8.0 & 8.2 \\
\hline Public & 5.5 & 3.8 & 3.5 & 2.7 & 1.9 & 1.6 \\
\hline \multicolumn{7}{|l|}{ Prices, wages and employment (annual average) } \\
\hline Harmonized index of consumer prices & 3.1 & -1.7 & -1.6 & 1.2 & 2.0 & 1.3 \\
\hline Average wage, whole economy & 3.5 & 0.0 & -1.9 & -0.5 & 0.5 & 0.8 \\
\hline Employment & -0.7 & -7.8 & -4.0 & -1.8 & -1.2 & 0.0 \\
\hline Unemployment rate (in percent) & 6.4 & 12.0 & 13.9 & 14.6 & 14.8 & 14.7 \\
\hline Money and credit (end-period) 3/ & & & & & & \\
\hline Irish resident private sector credit 4/ & 8.8 & -1.5 & -3.4 & -2.9 & -3.9 & $\cdots$ \\
\hline \multicolumn{7}{|l|}{ Financial and asset markets (end-period) 3/ } \\
\hline Three-month interbank rate & 2.9 & 0.7 & 1.0 & 1.4 & 0.3 & $\ldots$ \\
\hline Government bond yield (in percent, 10-year) 5/ & 4.4 & 4.9 & 9.2 & 8.5 & 4.9 & $\ldots$ \\
\hline Annual change in ISEQ index (in percent) & -33.8 & -23.4 & 13.2 & 3.0 & 19.2 & $\ldots$ \\
\hline House prices & -5.9 & -18.3 & -13.1 & -13.2 & -8.1 & $\ldots$ \\
\hline \multicolumn{7}{|l|}{ Public finance (in percent of GDP) } \\
\hline General government balance (excl. bank support & -7.3 & -11.5 & -10.7 & -9.1 & -8.3 & -7.5 \\
\hline Primary balance (excl. bank support) & -6.0 & -9.4 & -7.6 & -5.9 & -4.4 & -1.8 \\
\hline General government gross debt & 44.5 & 64.9 & 92.2 & 106.5 & 118.3 & 122.5 \\
\hline General government net debt & 23.0 & 41.8 & 74.5 & 94.9 & 103.7 & 107.3 \\
\hline \multicolumn{7}{|l|}{ External trade and balance of payments (percent of GDP) } \\
\hline Balance of goods and services & 9.0 & 15.9 & 18.6 & 21.9 & 24.5 & 26.1 \\
\hline Balance of income and current transfers & -14.7 & -18.2 & -17.5 & -20.8 & -22.2 & -22.9 \\
\hline Current account & -5.7 & -2.3 & 1.1 & 1.1 & 2.3 & 3.1 \\
\hline \multicolumn{7}{|l|}{ Effective exchange rates (1999:Q1=100, average) 3/ } \\
\hline Nominal & 111.6 & 112.5 & 107.8 & 108.6 & 103.8 & $\ldots$ \\
\hline Real (CPI based) & 123.1 & 121.0 & 111.6 & 110.2 & 105.0 & $\ldots$ \\
\hline \multicolumn{7}{|l|}{ Memorandum items: } \\
\hline Population (in millions) & 4.5 & 4.5 & 4.6 & 4.6 & 4.6 & 4.6 \\
\hline GDP per capita (in euros) & 39,884 & 35,575 & 34,356 & 34,753 & 35,397 & 36,023 \\
\hline GDP (in billions of euros) & 178.9 & 161.3 & 156.5 & 159.0 & 162.3 & 166.2 \\
\hline
\end{tabular}

Sources: Bloomberg; Central Bank of Ireland; Department of Finance; International Financial Statistics; and IMF staff estimates.

$1 /$ Contribution to growth.

2/ Excludes bank restructuring costs.

3/ 2012 column refers to the latest available information: end-August for the interbank rate, end-September for private sector credit, and end-October for government bond yield, change in the ISEQ index, and change 4/ Adjusted growth rate of credit to households and non-financial corporations.

5/ Since mid-2012, 8 year government bond yield is shown as no 10 year benchmark exists.

6/ General government balance per ESA95 definition. 
Table 2. Ireland: Medium-Term Scenario, 2008-17

(Annual percentage change, unless indicated otherwise)

\begin{tabular}{|c|c|c|c|c|c|c|c|c|c|c|c|}
\hline & 2008 & 2009 & 2010 & 2011 & 2012 & 2012 & 2013 & 2014 & 2015 & 2016 & 2017 \\
\hline & & & & & $7^{\text {th }}$ Rev. & \multicolumn{6}{|c|}{ Proj. } \\
\hline Real GDP & -2.1 & -5.5 & -0.8 & 1.4 & 0.4 & 0.4 & 1.1 & 2.2 & 2.8 & 2.9 & 2.9 \\
\hline Domestic demand & -3.7 & -11.0 & -4.2 & -3.7 & -2.3 & -2.9 & -0.9 & 0.9 & 1.7 & 2.1 & 2.3 \\
\hline Final domestic demand & -2.4 & -10.2 & -4.9 & -4.3 & -2.3 & -2.7 & -0.9 & 0.9 & 1.7 & 2.1 & 2.3 \\
\hline Private consumption & -0.1 & -5.4 & 1.0 & -2.4 & -1.9 & -2.1 & -0.5 & 1.2 & 1.8 & 1.8 & 2.0 \\
\hline Public consumption & 0.6 & -4.4 & -6.5 & -4.3 & -2.5 & -4.0 & -2.0 & -1.3 & -1.0 & 0.0 & 0.0 \\
\hline Gross fixed investment & -10.0 & -27.6 & -22.6 & -12.6 & -4.0 & -4.0 & -1.5 & 3.0 & 5.2 & 6.5 & 7.0 \\
\hline Change in stocks $1 /$ & -1.2 & -0.7 & 0.6 & 0.5 & 0.0 & -0.1 & 0.0 & 0.0 & 0.0 & 0.0 & 0.0 \\
\hline Net exports $1 /$ & 1.4 & 4.5 & 3.0 & 5.4 & 2.1 & 2.7 & 1.8 & 1.6 & 1.5 & 1.4 & 1.2 \\
\hline Exports of goods and services & -1.1 & -3.8 & 6.2 & 5.1 & 2.8 & 2.8 & 3.2 & 4.2 & 4.5 & 4.7 & 4.7 \\
\hline Imports of goods and senices & -3.0 & -9.7 & 3.6 & -0.3 & 1.0 & 0.3 & 2.1 & 3.7 & 4.2 & 4.7 & 4.9 \\
\hline Real GNP & -1.8 & -8.1 & 0.9 & -2.5 & -0.6 & -0.5 & 0.3 & 1.5 & 2.3 & 2.3 & 2.5 \\
\hline Current account 2/ & -5.7 & -2.3 & 1.1 & 1.1 & 1.8 & 2.3 & 3.1 & 3.8 & 4.0 & 4.1 & 4.1 \\
\hline Gross national saving 2/ & 16.3 & 13.5 & 13.1 & 11.3 & 11.6 & 11.7 & 12.5 & 13.6 & 14.0 & 14.4 & 14.8 \\
\hline Private & 18.2 & 21.2 & 20.4 & 17.7 & 19.5 & 18.2 & 18.3 & 16.9 & 15.3 & 15.0 & 14.9 \\
\hline Public & -1.9 & -7.7 & -7.2 & -6.4 & -7.9 & -6.5 & -5.8 & -3.3 & -1.2 & -0.5 & -0.2 \\
\hline Gross investment 2/ & 22.0 & 15.9 & 12.0 & 10.1 & 9.8 & 9.9 & 9.8 & 9.9 & 10.2 & 10.5 & 11.0 \\
\hline Private & 16.5 & 12.1 & 8.5 & 7.5 & 7.8 & 8.0 & 8.2 & 8.2 & 8.5 & 8.9 & 9.4 \\
\hline Public & 5.5 & 3.8 & 3.5 & 2.7 & 1.9 & 1.9 & 1.6 & 1.7 & 1.7 & 1.6 & 1.6 \\
\hline \multicolumn{12}{|l|}{ Prices } \\
\hline Harmonized index of consumer prices & 3.1 & -1.7 & -1.6 & 1.2 & 1.4 & 2.0 & 1.3 & 1.4 & 1.6 & 1.8 & 1.8 \\
\hline GDP deflator & -3.2 & -4.6 & -2.2 & 0.2 & 1.3 & 1.6 & 1.3 & 1.4 & 1.6 & 1.6 & 1.6 \\
\hline Average wage, whole economy & 3.5 & 0.0 & -1.9 & -0.5 & 0.3 & 0.5 & 0.8 & 1.2 & 1.6 & 1.9 & 2.0 \\
\hline \multicolumn{12}{|l|}{ Labor market } \\
\hline Employment & -0.7 & -7.8 & -4.0 & -1.8 & -0.8 & -1.2 & 0.0 & 0.9 & 1.9 & 2.0 & 2.1 \\
\hline Unemployment rate (in percent) & 6.4 & 12.0 & 13.9 & 14.6 & 14.8 & 14.8 & 14.7 & 14.2 & 13.4 & 12.5 & 11.7 \\
\hline \multicolumn{12}{|l|}{ Public finance } \\
\hline General government balance 2/ 3/ & -7.3 & -11.5 & -10.7 & -9.1 & -8.3 & -8.3 & -7.5 & -5.0 & -2.9 & -2.1 & -1.7 \\
\hline General government gross debt 2/ & 44.5 & 64.9 & 92.2 & 106.5 & 117.7 & 118.3 & 122.5 & 121.7 & 118.0 & 115.3 & 112.1 \\
\hline General government net debt 2/ & 23.0 & 41.8 & 74.5 & 94.9 & 103.0 & 103.7 & 107.3 & 109.1 & 107.6 & 105.3 & 102.4 \\
\hline Output gap & 3.5 & -2.4 & -3.2 & -2.0 & -2.3 & -2.1 & -1.9 & -1.2 & -0.4 & 0.1 & 0.3 \\
\hline Nominal GDP (in billions of euros) & 178.9 & 161.3 & 156.5 & 159.0 & 161.7 & 162.3 & 166.2 & 172.3 & 179.9 & 188.0 & 196.4 \\
\hline
\end{tabular}

Sources: Central Statistics Office; Department of Finance; and IMF staff estimates.

1/ Contributions to growth.

2/ In percent of GDP, excludes bank restructuring costs.

3/ General government balance per ESA95 definition. 
Table 3. Ireland: General Government Finances, 2008-17

(In billions of euros)

\begin{tabular}{|c|c|c|c|c|c|c|c|c|c|c|}
\hline & 2008 & 2009 & 2010 & 2011 & 2012 & 2013 & 2014 & 2015 & 2016 & 2017 \\
\hline & & & & & \multicolumn{6}{|c|}{ Proj. 3/ } \\
\hline Revenue & 63.0 & 54.1 & 53.2 & 54.2 & 55.5 & 57.3 & 59.9 & 62.2 & 64.2 & 66.8 \\
\hline Direct taxes & 33.0 & 28.1 & 27.1 & 28.4 & 29.0 & 30.3 & 32.0 & 33.9 & 35.5 & 37.3 \\
\hline Personal income tax & 13.2 & 11.8 & 11.3 & 13.8 & 14.5 & 15.1 & 15.8 & 16.8 & 17.7 & 18.7 \\
\hline Pay-related social insurance $1 /$ & 11.9 & 11.6 & 11.3 & 10.1 & 9.5 & 9.9 & 10.3 & 10.7 & 11.0 & 11.3 \\
\hline Corporate income tax & 5.1 & 3.9 & 3.9 & 3.8 & 4.2 & 4.5 & 4.9 & 5.3 & 5.7 & 6.1 \\
\hline Capital taxes & 2.9 & 0.8 & 0.6 & 0.7 & 0.8 & 0.9 & 1.0 & 1.1 & 1.2 & 1.2 \\
\hline Indirect taxes & 20.5 & 16.3 & 15.7 & 15.8 & 16.1 & 16.8 & 17.7 & 18.0 & 18.7 & 19.4 \\
\hline Value-added tax & 13.4 & 10.7 & 10.1 & 9.7 & 10.0 & 10.2 & 10.8 & 11.3 & 11.7 & 12.2 \\
\hline Excise tax & 5.4 & 4.7 & 4.7 & 4.7 & 4.8 & 5.1 & 5.3 & 5.5 & 5.7 & 5.9 \\
\hline Stamp duty & 1.7 & 0.9 & 1.0 & 1.4 & 1.3 & 1.5 & 1.6 & 1.2 & 1.3 & 1.3 \\
\hline Miscellaneous 2/ & 9.5 & 9.7 & 10.4 & 10.1 & 10.4 & 10.1 & 10.2 & 10.3 & 10.0 & 10.1 \\
\hline Expenditure (ex. bank support) & 76.1 & 72.6 & 70.0 & 68.7 & 69.0 & 69.7 & 68.5 & 67.4 & 68.3 & 70.2 \\
\hline Current & 63.3 & 65.4 & 64.3 & 63.8 & 64.9 & 65.9 & 64.5 & 63.4 & 64.2 & 66.1 \\
\hline Interest payments & 2.4 & 3.2 & 4.9 & 5.1 & 6.4 & 9.4 & 9.7 & 10.0 & 10.2 & 10.9 \\
\hline Goods and services & 10.0 & 9.8 & 9.0 & 8.3 & 8.4 & 7.8 & 7.5 & 7.3 & 7.6 & 7.7 \\
\hline Compensation of emp & 21.1 & 20.5 & 19.0 & 18.9 & 19.0 & 18.5 & 18.2 & 17.9 & 18.2 & 18.5 \\
\hline Current transfers & 29.8 & 31.9 & 31.4 & 31.6 & 31.1 & 30.1 & 29.1 & 28.2 & 28.3 & 28.9 \\
\hline Capital (excl. bank support) & 12.8 & 7.2 & 5.6 & 4.9 & 4.1 & 3.8 & 4.0 & 4.0 & 4.1 & 4.2 \\
\hline Net acquisition of non-financi & 9.8 & 6.1 & 5.4 & 4.2 & 2.8 & 2.7 & 3.0 & 3.0 & 3.1 & 3.1 \\
\hline Capital transfers (ex. bank s & 3.1 & 1.1 & 0.2 & 0.7 & 1.3 & 1.1 & 1.0 & 1.0 & 1.0 & 1.1 \\
\hline Bank support costs & 0.0 & 4.0 & 31.6 & 6.8 & 0.0 & 0.0 & 0.0 & 0.0 & 0.0 & 0.0 \\
\hline \multirow{2}{*}{$\begin{array}{l}\text { Net lending/borrowing (ex. bank support) } 4 \text { / } \\
\text { Including bank support }\end{array}$} & -13.1 & -18.5 & -16.8 & -14.5 & -13.5 & -12.4 & -8.7 & -5.2 & -4.0 & -3.4 \\
\hline & -13.1 & -22.5 & -48.3 & -21.3 & -13.5 & -12.4 & -8.7 & -5.2 & -4.0 & -3.4 \\
\hline GG primary balance (ex. bank support) & -10.7 & -15.2 & -11.8 & -9.3 & -7.1 & -3.0 & 1.0 & 4.8 & 6.1 & 7.5 \\
\hline Including bank support & -10.7 & -19.2 & -43.4 & -16.1 & -7.1 & -3.0 & 1.0 & 4.8 & 6.1 & 7.5 \\
\hline \multicolumn{11}{|c|}{ Memorandum items (in percent of GDP, unless indicated otherwise) } \\
\hline Revenue & 35.2 & 33.6 & 34.0 & 34.1 & 34.2 & 34.5 & 34.8 & 34.6 & 34.2 & 34.0 \\
\hline Direct & 18.4 & 17.4 & 17.3 & 17.8 & 17.9 & 18.3 & 18.6 & 18.9 & 18.9 & 19.0 \\
\hline Indirect & 11.5 & 10.1 & 10.1 & 9.9 & 9.9 & 10.1 & 10.3 & 10.0 & 9.9 & 9.9 \\
\hline Miscellaneous 2/ & 5.3 & 6.0 & 6.6 & 6.3 & 6.4 & 6.1 & 5.9 & 5.7 & 5.3 & 5.2 \\
\hline Expenditure (ex. bank support) & 42.6 & 45.0 & 44.7 & 43.2 & 42.5 & 41.9 & 39.8 & 37.5 & 36.3 & 35.7 \\
\hline Primary current & 34.1 & 38.5 & 38.0 & 36.9 & 36.1 & 34.0 & 31.8 & 29.7 & 28.8 & 28.1 \\
\hline Interest & 1.3 & 2.0 & 3.1 & 3.2 & 3.9 & 5.7 & 5.6 & 5.6 & 5.4 & 5.6 \\
\hline Capital $(\epsilon$ & 7.2 & 4.4 & 3.6 & 3.1 & 2.5 & 2.3 & 2.3 & 2.2 & 2.2 & 2.1 \\
\hline Net lending/borrowing 4/ & -7.3 & -11.5 & -10.7 & -9.1 & -8.3 & -7.5 & -5.0 & -2.9 & -2.1 & -1.7 \\
\hline Including bank support & -7.3 & -13.9 & -30.9 & -13.4 & -8.3 & -7.5 & -5.0 & -2.9 & -2.1 & -1.7 \\
\hline Primary balance & -6.0 & -9.4 & -7.6 & -5.9 & -4.4 & -1.8 & 0.6 & 2.7 & 3.3 & 3.8 \\
\hline Including bank s & -6.0 & -11.9 & -27.7 & -10.1 & -4.4 & -1.8 & 0.6 & 2.7 & 3.3 & 3.8 \\
\hline Structural balance & -11.5 & -11.3 & -9.6 & -7.8 & -6.6 & -5.4 & -3.5 & -2.1 & -1.9 & -1.8 \\
\hline Structural primary balance 5/ & -10.5 & -9.1 & -6.2 & -4.5 & -2.6 & 0.3 & 2.1 & 3.5 & 3.6 & 3.7 \\
\hline General government gross debt & 44.5 & 64.9 & 92.2 & 106.5 & 118.3 & 122.5 & 121.7 & 118.0 & 115.3 & 112.1 \\
\hline General government net debt & 23.0 & 41.8 & 74.5 & 94.9 & 103.7 & 107.3 & 109.1 & 107.6 & 105.3 & 102.4 \\
\hline Nominal GDP (in billions of euros) & 178.9 & 161.3 & 156.5 & 159.0 & 162.3 & 166.2 & 172.3 & 179.9 & 188.0 & 196.4 \\
\hline
\end{tabular}

Sources: Department of Finance; IMF and staff estimates.

1/ Includes imputed social insurance contributions, which are recorded symmetrically under compensation of exployees. The 2011 downward jump in the series reflects the integration of health levy receipts into the universal social charge (now part of income tax).

2/ These include bank-related revenues, customs duties, unallocated tax receipts, training and employment lew, trading, rental and investment incomes, and transfers from the rest of the world (not elsewhere included).

3/ The projections for 2012-15 are consistent with the adjustment path set out in the Medium-Term Fiscal Statement and specified in Budget 2012.

4/ Corresponds to the general government balance, as per ESA95 definitions.

$5 /$ In percent of nominal potential GDP. 
Table 4. Ireland: Indicators of External and Financial Vulnerability, 2008-12

\begin{tabular}{|c|c|c|c|c|c|}
\hline & 2008 & 2009 & 2010 & 2011 & $20127 /$ \\
\hline \multicolumn{6}{|l|}{ External indicators } \\
\hline Exports (annual percent change, value in euros) & -1.4 & -2.5 & 7.8 & 5.7 & 5.0 \\
\hline Imports (annual percent change, value in euros) & -1.1 & -10.1 & 6.6 & 2.8 & 2.6 \\
\hline Terms of trade (goods, annual percent change) & -2.3 & 1.7 & -1.2 & -2.9 & -0.1 \\
\hline Current account balance (in percent of GDP) & -5.7 & -2.3 & 1.1 & 1.1 & 2.3 \\
\hline Capital and financial account balance (in percent of GDP) & 9.0 & -1.4 & 4.2 & -18.0 & -13.3 \\
\hline \multicolumn{6}{|l|}{ Of which: } \\
\hline Inward portfolio investment & -10.2 & 13.8 & 48.3 & 19.2 & 2.3 \\
\hline Inward foreign direct investment & -6.3 & 11.5 & 20.7 & 5.2 & 3.6 \\
\hline Other investment liabilities & 86.0 & -53.6 & -39.6 & -52.0 & -43.1 \\
\hline U.S. dollar per euro (period average) & 1.47 & 1.39 & 1.33 & 1.39 & 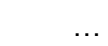 \\
\hline U.K. pound per euro (period average) & 0.79 & 0.89 & 0.86 & 0.87 & \\
\hline \multicolumn{6}{|l|}{ Financial markets indicators } \\
\hline General government debt (in percent of GDP) & 44.5 & 64.9 & 92.2 & 106.5 & 118.3 \\
\hline Government bond yield (in percent, 10-year, end-period) 1/ & 4.4 & 4.9 & 9.2 & 8.5 & 4.9 \\
\hline Spread of government bond yield with Germany (in percent, end of period) & 0.5 & 2.0 & 3.2 & 7.1 & 3.4 \\
\hline Real government bond yield (in percent, 10 -year, period average, based on HICP) & 1.4 & 6.9 & 7.6 & 8.5 & 2.8 \\
\hline Annual change in ISEQ index (in percent, end of period) & -33.8 & -23.4 & 13.2 & 3.0 & 19.2 \\
\hline Personal lending interest rate (in percent) & 11.9 & 11.1 & 11.4 & 11.6 & 11.6 \\
\hline Standard variable mortgage interest rate (in percent) & 4.8 & 3.3 & 4.0 & 4.2 & 4.2 \\
\hline \multicolumn{6}{|l|}{ Financial sector risk indicators } \\
\hline Annual credit growth rates (to Irish resident private sector, in percent) 2/ & 8.8 & -1.5 & -3.4 & -2.9 & -3.9 \\
\hline Personal lending as a share of total Irish resident credit (in percent) & 35.2 & 35.6 & 35.8 & 30.0 & 30.0 \\
\hline \multicolumn{6}{|l|}{ Of which: } \\
\hline House mortgage finance & 29.0 & 30.1 & 30.6 & 25.4 & 26.1 \\
\hline Other housing finance & 0.3 & 0.2 & 0.3 & 0.3 & 0.3 \\
\hline Other personal lending & 5.9 & 5.3 & 5.2 & 4.6 & 4.4 \\
\hline Irish resident household mortgage debt annual growth rates (in percent) 3/ & -7.1 & -3.9 & -9.0 & -19.3 & -18.4 \\
\hline Foreign-currency denominated assets (in percent of total assets) & 31.7 & 34.3 & 30.3 & 29.4 & 29.5 \\
\hline Foreign-currency denominated liabilities (in percent of total liabilities) & 35.5 & 31.1 & 25.8 & 26.3 & 25.9 \\
\hline Non-performing loans (in percent of total loans) 4 / & 2.6 & 9.0 & 8.6 & 9.1 & 9.9 \\
\hline Total provisions for loan losses (in percent of total loans) & 1.2 & 4.0 & 4.2 & 4.8 & 5.3 \\
\hline Regulatory capital to risk-weighted assets of domestic banks (in percent) & 10.6 & 10.9 & 10.4 & 17.5 & 17.7 \\
\hline Bank return on assets (before tax, in percent) & -0.3 & -1.6 & -3.1 & -0.9 & $\ldots$ \\
\hline Bank return on equity (before tax, in percent) & -8.0 & -40.6 & -67.6 & -18.2 & $\ldots$ \\
\hline Deposits to $\mathrm{M} 3$ ratio $5 /$ & 1.4 & 1.4 & 1.5 & 1.2 & 1.3 \\
\hline Loan-to-deposit ratio vis-à-vis Irish residents 6/ & 2.2 & 2.1 & 2.1 & 2.1 & 2.0 \\
\hline vis-à-vis total $6 /$ & 2.2 & 2.2 & 2.1 & 2.1 & 2.0 \\
\hline \multicolumn{6}{|l|}{ Concentration ratios in the banking sector } \\
\hline No. of banks accounting for 25 percent of total assets & 2 & 2 & 2 & 2 & 2 \\
\hline No. of banks accounting for 75 percent of total assets & 14 & 13 & 13 & 14 & 14 \\
\hline Share of state-owned banks in total assets (in percent) & 0.0 & 6.0 & 8.0 & 18 & 19 \\
\hline Share of foreign-owned banks in total assets (in percent) & 62.0 & 65.0 & 66.0 & 62 & 59 \\
\hline
\end{tabular}

Sources: Bloomberg; Central Bank of Ireland; International Financial Statistics; and IMF staff estimates.

1/ Since mid-2012, 8 year government bond yield is shown as no 10 year benchmark exists.

2/ Adjusted growth rate of credit to households and non-financial corporations.

3/ Including securitisations.

4/ Owing to differences in classification, international comparisons of nonperforming loans are indicative only.

5/ Deposits vis-à-vis Irish and nonresidents. The M3 compiliation methodology has been amended in line with Eurosystem requirements.

6/ Nongovernment credit/nongovernment deposits ratio.

7/ For 2012, staff projections for macroeconomic variables and debt, end-March for personal and mortgage lending rates, end-June for other banking sector indicators, and end-October for financial market indicators. Financial sector indiators cover all credit institutions licensed in Ireland except for personal lending rate, which is calculated based on a sample of retail banks, and a mortgage interest rate, which is calculated excluding IFSC. 
Table 5. Ireland: Summary of Balance of Payments, 2008-17

\begin{tabular}{|c|c|c|c|c|c|c|c|c|c|c|}
\hline & 2008 & 2009 & 2010 & 2011 & 2012 & 2013 & 2014 & 2015 & 2016 & 2017 \\
\hline & \multicolumn{10}{|c|}{ Proj. } \\
\hline & \multicolumn{10}{|c|}{ (In billions of euros) } \\
\hline Current account balance & -10.2 & -3.8 & 1.8 & 1.8 & 3.8 & 5.2 & 6.6 & 7.3 & 7.7 & 8.1 \\
\hline Balance of goods and services & 16.1 & 25.6 & 29.1 & 34.8 & 39.7 & 43.3 & 46.6 & 50.0 & 53.2 & 56.4 \\
\hline Trade balance & 23.8 & 32.5 & 35.8 & 36.6 & 38.2 & 40.6 & 43.4 & 46.7 & 50.0 & 53.0 \\
\hline Exports of goods & 81.0 & 77.6 & 82.6 & 84.9 & 87.4 & 91.3 & 96.1 & 101.4 & 106.9 & 111.7 \\
\hline Imports of goods & -57.2 & -45.2 & -46.9 & -48.3 & -49.2 & -50.8 & -52.6 & -54.8 & -56.8 & -58.6 \\
\hline Services balance & -7.7 & -6.9 & -6.6 & -1.8 & 1.5 & 2.7 & 3.2 & 3.3 & 3.2 & 3.3 \\
\hline Credit & 67.9 & 67.6 & 74.3 & 81.4 & 87.6 & 91.6 & 96.3 & 101.7 & 108.1 & 116.0 \\
\hline Debit & -75.6 & -74.5 & -81.0 & -83.3 & -86.1 & -88.9 & -93.2 & -98.4 & -104.9 & -112.7 \\
\hline Income balance & -25.2 & -27.9 & -25.9 & -31.8 & -34.8 & -36.9 & -38.8 & -41.4 & -44.1 & -46.8 \\
\hline Credit & 84.0 & 55.1 & 57.1 & 55.9 & 54.8 & 54.8 & 56.3 & 57.9 & 59.6 & 61.6 \\
\hline Debit & -109.2 & -83.0 & -83.0 & -87.7 & -89.5 & -91.7 & -95.1 & -99.3 & -103.7 & -108.4 \\
\hline Current transfers (net) & -1.2 & -1.4 & -1.4 & -1.2 & -1.2 & -1.2 & -1.3 & -1.3 & -1.4 & -1.4 \\
\hline Capital and financial account balance & 16.2 & -2.3 & 6.6 & -28.7 & -21.7 & -17.0 & -6.6 & -7.3 & -7.7 & -8.1 \\
\hline Capital account balance & 0.0 & -1.3 & -0.7 & -0.3 & -0.2 & -0.3 & -0.3 & -0.3 & -0.3 & -0.3 \\
\hline Financial account & 16.1 & -1.1 & 7.3 & -28.4 & -21.5 & -16.7 & -6.3 & -7.0 & -7.4 & -7.8 \\
\hline Direct investment & -24.2 & -0.6 & 15.4 & 11.3 & 8.9 & 8.7 & 8.4 & 8.6 & 8.5 & 8.4 \\
\hline Portfolio investment & -45.7 & 22.6 & 86.0 & 27.5 & 1.0 & -0.9 & -2.5 & -2.1 & -2.5 & -2.8 \\
\hline Other inv & 86.1 & -23.1 & -32.2 & -67.6 & -32.4 & -23.7 & -12.7 & -14.1 & -14.7 & -14.4 \\
\hline erve assets $1 /$ & -0.1 & 0.1 & 0.0 & 0.3 & 1.0 & -0.7 & 0.5 & 0.7 & 1.3 & 1.0 \\
\hline Net errors and omissions & -6.0 & 6.1 & -8.4 & -7.6 & -3.4 & 0.0 & 0.0 & 0.0 & 0.0 & 0.0 \\
\hline Financing gap & 0.0 & 0.0 & 0.0 & 34.5 & 21.3 & 11.7 & 0.0 & 0.0 & 0.0 & 0.0 \\
\hline Program financing & 0.0 & 0.0 & 0.0 & 34.5 & 21.3 & 11.7 & 0.0 & 0.0 & 0.0 & 0.0 \\
\hline IMF & 0.0 & 0.0 & 0.0 & 12.6 & 6.4 & 3.5 & 0.0 & 0.0 & 0.0 & 0.0 \\
\hline \multirow[t]{2}{*}{ EU } & 0.0 & 0.0 & 0.0 & 21.9 & 14.8 & 8.3 & 0.0 & 0.0 & 0.0 & 0.0 \\
\hline & \multicolumn{10}{|c|}{ (In percent of GDP) } \\
\hline Curren & -5.7 & -2.3 & 1.1 & 1.1 & 2.3 & 3.1 & 3.8 & 4.0 & 4.1 & 4.1 \\
\hline Balance of goods and services & 9.0 & 15.9 & 18.6 & 21.9 & 24.5 & 26.1 & 27.0 & 27.8 & 28.3 & 28.7 \\
\hline Trade balance & 13.3 & 20.1 & 22.8 & 23.0 & 23.5 & 24.4 & 25.2 & 25.9 & 26.6 & 27.0 \\
\hline Services balance & -4.3 & -4.3 & -4.2 & -1.1 & 1.0 & 1.6 & 1.8 & 1.8 & 1.7 & 1.7 \\
\hline Income balance & -14.1 & -17.3 & -16.6 & -20.0 & -21.4 & -22.2 & -22.5 & -23.0 & -23.5 & -23.8 \\
\hline Current transfers (net) & -0.6 & -0.9 & -0.9 & -0.7 & -0.7 & -0.7 & -0.7 & -0.7 & -0.7 & -0.7 \\
\hline $\begin{array}{l}\text { Capital and financial account balance } \\
\text { Of which: }\end{array}$ & 9.0 & -1.4 & 4.2 & -18.0 & -13.3 & -10.2 & -3.8 & -4.0 & -4.1 & -4.1 \\
\hline Direct investment & -13.5 & -0.4 & 9.9 & 7.1 & 5.5 & 5.2 & 4.9 & 4.8 & 4.5 & 4.3 \\
\hline Portfolio investment & -25.6 & 14.0 & 54.9 & 17.3 & 0.6 & -0.6 & -1.4 & -1.2 & -1.3 & -1.4 \\
\hline Other investment & 48.1 & -14.3 & -20.5 & -42.5 & -20.0 & -14.3 & -7.4 & -7.9 & -7.8 & -7.4 \\
\hline Change in reserve assets $1 /$ & 0.0 & 0.0 & 0.0 & 0.2 & 0.6 & -0.4 & 0.3 & 0.4 & 0.7 & 0.5 \\
\hline Net errors and omissions & -3.4 & 3.8 & -5.4 & -4.8 & -2.1 & 0.0 & 0.0 & 0.0 & 0.0 & 0.0 \\
\hline Financing gap & 0.0 & 0.0 & 0.0 & 21.7 & 13.1 & 7.1 & 0.0 & 0.0 & 0.0 & 0.0 \\
\hline Program financing & 0.0 & 0.0 & 0.0 & 21.7 & 13.1 & 7.1 & 0.0 & 0.0 & 0.0 & 0.0 \\
\hline IMF & 0.0 & 0.0 & 0.0 & 7.9 & 4.0 & 2.1 & 0.0 & 0.0 & 0.0 & 0.0 \\
\hline EU & 0.0 & 0.0 & 0.0 & 13.8 & 9.1 & 5.0 & 0.0 & 0.0 & 0.0 & 0.0 \\
\hline
\end{tabular}

Sources: Central Bank of Ireland; Central Statistics Office; and IMF staff estimates.

$1 /$ Includes financing need to build reserves for bank support. 
Table 6. Ireland: Monetary Survey, 2008-12

(In billions of euros, unless otherwise indicated; end of period)

\begin{tabular}{|c|c|c|c|c|c|c|c|}
\hline & Dec-08 & Dec-09 & Dec-10 & Dec-11 & Mar-12 & Jun-12 & Sep-12 \\
\hline \multicolumn{8}{|c|}{ Aggregate balance sheet of domestic market credit institutions } \\
\hline Assets & 801 & 798 & 742 & 634 & 610 & 604 & 567 \\
\hline Claims on Central Bank of Ireland & 9 & 12 & 8 & 4 & 5 & 6 & 7 \\
\hline Claims on Irish resident Other MFIs & 125 & 129 & 123 & 92 & 86 & 81 & 55 \\
\hline Claims on Irish resident non MFIs & 374 & 363 & 357 & 338 & 337 & 332 & 330 \\
\hline General government & 3 & 9 & 43 & 42 & 44 & 45 & 47 \\
\hline Private sector & 371 & 354 & 314 & 296 & 293 & 287 & 284 \\
\hline Households & 144 & 139 & 129 & 109 & 108 & 108 & 106 \\
\hline Non-Financial Corporations & 163 & 144 & 90 & 85 & 85 & 84 & 84 \\
\hline Non-Bank Financial Intermediaries & 64 & 71 & 95 & 101 & 100 & 96 & 94 \\
\hline Claims on non-residents & 250 & 241 & 206 & 147 & 139 & 138 & 129 \\
\hline Other assets & 44 & 54 & 47 & 52 & 44 & 46 & 46 \\
\hline Liabilities & 801 & 798 & 742 & 634 & 610 & 604 & 567 \\
\hline Liabilities to Eurosystem 1/ & 45 & 58 & 95 & 72 & 75 & 76 & 70 \\
\hline Liabilities to Irish resident Other MFIs & 126 & 131 & 132 & 99 & 92 & 87 & 60 \\
\hline Deposits of Irish resident non MFIs & 170 & 180 & 161 & 144 & 145 & 145 & 146 \\
\hline General government & 3 & 3 & 3 & 2 & 2 & 3 & 3 \\
\hline Private sector & 167 & 176 & 157 & 141 & 142 & 142 & 143 \\
\hline Households & 85 & 99 & 94 & 91 & 91 & 91 & 92 \\
\hline Non-Financial Corporations & 41 & 39 & 31 & 28 & 27 & 27 & 27 \\
\hline Non-Bank Financial Intermediaries & 40 & 38 & 32 & 23 & 24 & 24 & 25 \\
\hline Deposits of non-residents & 271 & 229 & 137 & 98 & 91 & 90 & 83 \\
\hline Debt securities & 100 & 98 & 64 & 52 & 44 & 41 & 39 \\
\hline Capital and reserves & 41 & 53 & 71 & 91 & 93 & 97 & 97 \\
\hline Other liabilities (incl. Central Bank of Ireland) & 48 & 50 & 83 & 78 & 70 & 69 & 71 \\
\hline \multicolumn{8}{|l|}{ Money and credit 2/ } \\
\hline Net foreign assets & -100 & -75 & -67 & -39 & -34 & -25 & $\ldots$ \\
\hline Central Bank of Ireland 3/ & -24 & -37 & -128 & -101 & -76 & -77 & 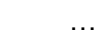 \\
\hline Commercial banks & -77 & -38 & 61 & 62 & 42 & 52 & 52 \\
\hline Net domestic assets & 295 & 283 & 239 & 208 & 203 & 193 & $\ldots$ \\
\hline Public sector credit & 3 & 10 & 43 & 43 & 44 & 46 & 47 \\
\hline Private sector credit & 394 & 375 & 335 & 324 & 319 & 313 & 309 \\
\hline Other & -102 & -102 & -139 & -158 & -160 & -165 & $\ldots$ \\
\hline Irish Resident Broad money (M3) 4/ & 194 & 208 & 173 & 169 & 169 & 168 & 170 \\
\hline Irish Resident Intermediate money (M2) 4/ & 176 & 188 & 173 & 167 & 167 & 166 & 168 \\
\hline Irish Resident Narrow money (M1) & 78 & 100 & 97 & 90 & 89 & 89 & 90 \\
\hline \multicolumn{8}{|c|}{ (percent of GDP) } \\
\hline Public sector credit 5/ & 1.4 & 5.3 & 27.6 & 27.0 & 28.2 & 28.4 & 29.0 \\
\hline Private sector credit $5 /$ & 206.1 & 220.4 & 201.5 & 189.1 & 185.9 & 180.1 & 176.8 \\
\hline \multicolumn{8}{|c|}{ (y-o-y percentage change) } \\
\hline Broad money - Irish contribution to euro area M3 6/ & -0.4 & -5.3 & -19.5 & 1.3 & -3.3 & -10.3 & -7.2 \\
\hline Irish Public sector credit 6/ 7/ & 101.8 & 176.9 & 369.4 & 1.5 & 11.0 & 15.3 & 8.5 \\
\hline $\begin{array}{l}\text { Irish Household and non-financial corporations credit } \\
\text { Memorandum items: } 8 /\end{array}$ & 8.8 & -1.5 & -3.4 & -2.9 & -3.2 & -3.4 & -3.9 \\
\hline Credit to deposits (in percent) 9/ & 222.8 & 200.8 & 200.0 & 209.2 & 205.5 & 201.7 & 197.9 \\
\hline Deposits from Irish Private Sector (y-o-y percent char & 1.1 & 2.1 & -9.8 & -9.2 & -5.6 & -2.8 & 0.7 \\
\hline Wholesale funding (billions of euros) & 440 & 423 & 315 & 234 & 213 & 203 & 168 \\
\hline Deposits from MFIs & 339 & 325 & 251 & 182 & 169 & 163 & 129 \\
\hline Debt securities & 100 & 98 & 64 & 52 & 44 & 41 & 39 \\
\hline Wholesale funding (y-o-y percent change) 10/ & 14.9 & 0.1 & -21.9 & -27.1 & -25.3 & -19.5 & -33.7 \\
\hline Wholesale funding (percent of assets) $10 /$ & 54.8 & 53.0 & 44.8 & 36.8 & 36.3 & 33.3 & 29.9 \\
\hline
\end{tabular}

Sources: Central Bank or Ireland and staff estimates.

1/ Relating to Eurosystem monetary policy operations.

2/ Including banks in the International Financial Service Centre.

$3 /$ Sourced from quarterly IIP statistics.

4/ Differs from the M3 (M2) Irish contribution to euro area as only liabilities vis-a-vis Irish residents are used.

5/ Refers to credit advanced by domestic market credit institutions.

6/ Includes IFSC.

7/ Growth rates adjusted for valuation, reclassification, derecognition/loan transfer to non-MFIs, and exchange rates.

8/ Excludes IFSC.

9/ Domestic market credit institutions' private sector credit to deposits.

10/ Includes resident and non-resident MFI deposits, and debt securities issued. 
Table 7. Ireland: PCAR Banks' Aggregated Summary Financial Statements, 2011-12

(In billions of euro, unless otherwise indicated)

\begin{tabular}{|c|c|c|c|c|c|c|c|c|c|}
\hline \multirow{2}{*}{ Balance Sheet } & \multicolumn{2}{|c|}{ Sept. 2011 Sept. 2012} & \multicolumn{2}{|c|}{ Year/year change } & \multirow{2}{*}{ Profit and Loss Account } & \multicolumn{2}{|c|}{ 2011, Q1-Q3 } & \multicolumn{2}{|c|}{ 2012, Q1-Q3 } \\
\hline & EUR bn & EUR bn & EUR bn & $\%$ & & EUR bn & $\%$ of TAA & EUR bn & $\%$ of TAA \\
\hline Cash \& due from Eurosystem & 5.0 & 19.1 & 14.0 & 278.3 & Interest income & 7.8 & 3.1 & 6.9 & 2.9 \\
\hline Net loans & 223.1 & 203.4 & -19.6 & -8.8 & Interest expense & -5.5 & -2.2 & -5.0 & -2.1 \\
\hline Due from banks & 15.7 & 14.6 & -1.1 & -7.2 & Net interest margin & 2.4 & 0.9 & 1.9 & 0.8 \\
\hline Securities \& derivatives & 71.2 & 66.6 & -4.7 & -6.6 & Net fee income & 0.7 & 0.3 & 0.7 & $\overline{0.3}$ \\
\hline Other assets & 14.8 & 13.1 & -1.8 & -11.9 & Net trading gains & 1.0 & 0.4 & -0.3 & -0.1 \\
\hline Total assets & 329.9 & \begin{tabular}{ll|}
316.7 \\
\end{tabular} & -13.2 & -4.0 & Other nonrecurrent items & 4.7 & 1.9 & -0.4 & -0.2 \\
\hline \multirow[t]{2}{*}{ Total average assets (TAA) $1 /$} & ב333.5 & 321.1 & -12.4 & $\overline{-3.7}$ & Gross operating income & 8.7 & 3.5 & 1.9 & 0.8 \\
\hline & & & & & Operating expenses & -2.5 & -1.0 & -3.0 & -1.3 \\
\hline Due to Eurosystem & 76.2 & 60.9 & -15.2 & -20.0 & o/w: administration \& other & -1.0 & \begin{tabular}{l|l}
-0.4 \\
\end{tabular} & -1.2 & -0.5 \\
\hline Due to banks & 18.0 & 16.1 & -1.9 & -10.4 & o/w: staff & -1.5 & -0.6 & -1.8 & -0.7 \\
\hline Deposits & 143.7 & 156.2 & 12.5 & 8.7 & Preprovision profits (PPP) & 6.2 & 2.5 & -1.2 & -0.5 \\
\hline Debt \& derivatives & 52.2 & 50.7 & -1.5 & -2.9 & Loan loss \& NAMA provisions & -8.1 & -3.2 & -3.9 & -1.6 \\
\hline Other liabilities & 6.9 & 8.4 & 1.5 & 21.5 & Loss on derecognized assets & 0.1 & 0.1 & -0.1 & 0.0 \\
\hline Total liabilities & 297.1 & 292.5 & -4.6 & -1.6 & Net income before tax & -1.8 & -0.7 & -5.1 & -2.1 \\
\hline Net equity & 32.9 & 24.2 & -8.6 & -26.3 & Tax effects \& other $3 /$ & 2.3 & 0.9 & 0.5 & 0.2 \\
\hline Total liabilities \& equity & 330.0 & 316.7 & -13.3 & -4.0 & Net income & 0.5 & 0.2 & -4.6 & -1.9 \\
\hline \multicolumn{10}{|l|}{ Memorandum items: } \\
\hline Gross loans 2/ & 247.2 & 229.6 & -17.7 & -7.1 & PPP net of other nonrecurrent items & 1.5 & 0.6 & -0.8 & -0.3 \\
\hline Loan loss provisions & 19.5 & 26.5 & 7.0 & 35.8 & Return on equity & & 3.5 & & -23.2 \\
\hline Gross NPLs & 42.1 & 53.0 & 10.9 & 26.0 & Provisions to gross loans & & 3.5 & & 2.2 \\
\hline Gross NPLs to gross loans (\%) & 17.0 & 23.1 & & 6.1 & Risk weighted assets (RWA) & 174.6 & 52.3 & 153.8 & 47.9 \\
\hline Provisions to gross NPLs (\%) & 46.4 & 50.0 & & 3.6 & Core tier 1 capital (CT1) and CT1 to RWA (\%) & 30.7 & 17.6 & 23.8 & 15.5 \\
\hline Net NPLs to net equity (\%) & 68.6 & 109.3 & & 40.7 & $\mathrm{CT} 1$ to total assets $=$ leverage ratio $(\%)$ & & 9.3 & & 7.5 \\
\hline
\end{tabular}

Sources: $\mathrm{CBI}$ and IMF staff estimates.

1/ TAA denotes total average assets net of loan loss provisions over the reporting period. In June 2011 Irish Nationwide was included in the data as a PCAR bank, on 1 July it was merged with IBRC and is no longer included. This would reduce comparable total assets in June 2011 by $€ 6.3$ bn. EBS and AIB merged on 1 July 2012 and are consolidated only since June 2012 with minimal accounting impact.

2/ Includes loans held for sale, classified on balance sheet as other assets.

3/ Includes profits from discontinued operations of €1.6 billion in Q1-Q3 2011 and $€ 0.0$ billion in Q1-Q3 2012. 
Table 8. Ireland: General Government Financing Requirements and Sources, 2008-13 (In billions of euros)

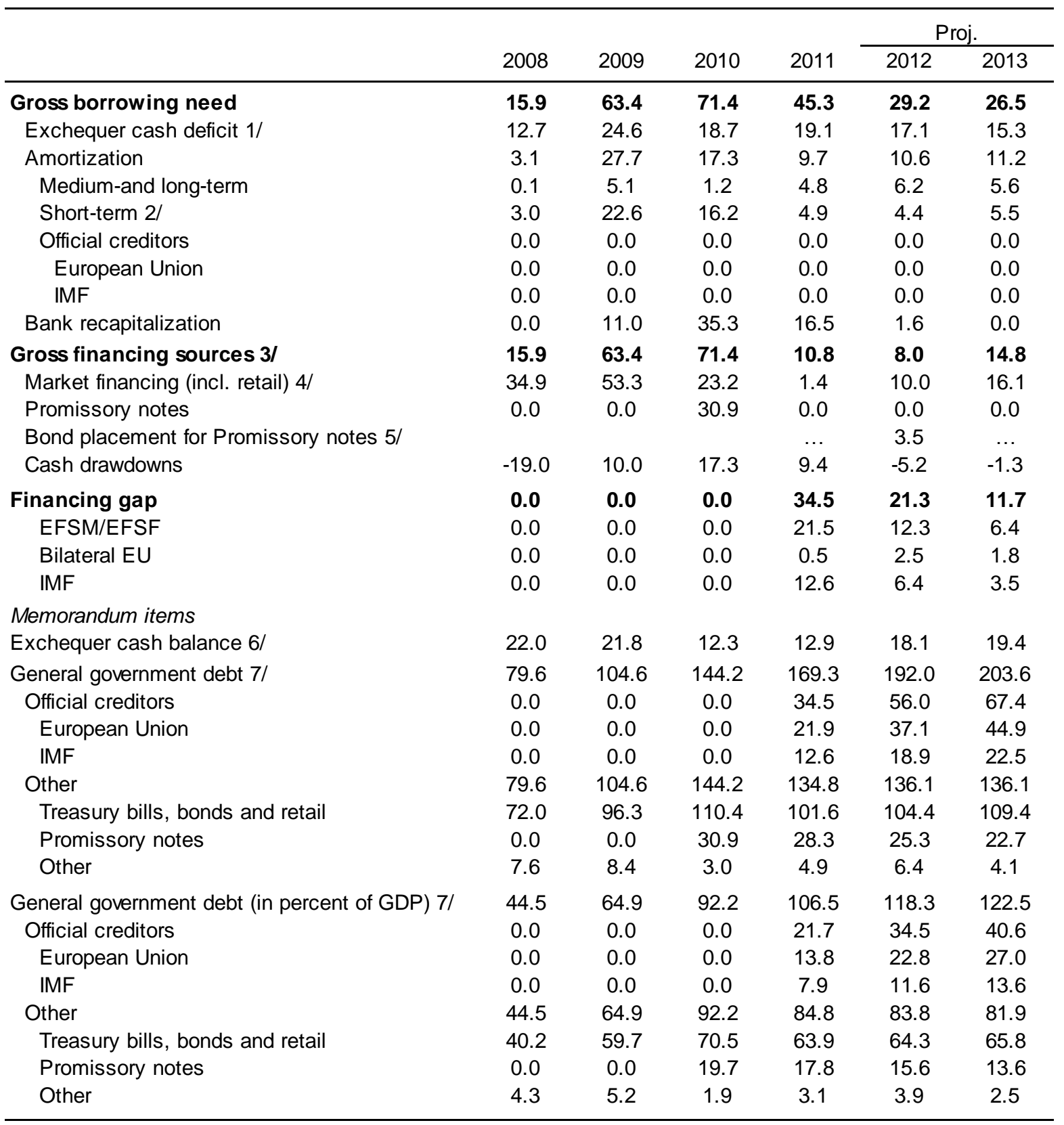

Sources: Department of Finance; National Treasury Management Agency; and IMF staff estimates.

1/ Includes allowance for amortization of Promissory notes and contingency for collateral on hedging transactior

2/ Gross amortization of Treasury bills, Exchequer notes, and commercial paper.

3/ Includes stock-flow adjustment arising from the March 2012 payment of Promissory notes.

4/ Gross issuance including rollovers.

5/ Placement of a bond for the March 2012 payment of Promissory notes to IBRC.

$6 /$ Includes buffer from financing contingency.

7/ Includes local debt, other national debt, and other general government debt on consolidated level. 
Table 9. Ireland: Schedule of Reviews and Purchases

\begin{tabular}{|c|c|c|c|c|}
\hline \multirow[t]{2}{*}{ Review } & \multirow[t]{2}{*}{ Availability Date } & \multirow[t]{2}{*}{ Action } & \multicolumn{2}{|c|}{ Purchase } \\
\hline & & & SDRs & Percent of quota \\
\hline & December 16, 2010 & Board approval of arrangement & $5,012,425,200$ & 399 \\
\hline First and Second Reviews & May 16, 2011 & $\begin{array}{l}\text { Observance of end-March } 2011 \text { performance criteria, completion of First } \\
\text { and Second Reviews }\end{array}$ & $1,410,000,000$ & 112 \\
\hline Third Review & August 15, 2011 & $\begin{array}{l}\text { Observance of end-June } 2011 \text { performance criteria, completion of Third } \\
\text { Review }\end{array}$ & $1,319,000,000$ & 105 \\
\hline Fourth Review & December 14, 2011 & $\begin{array}{l}\text { Observance of end-September } 2011 \text { performance criteria, completion of } \\
\text { Fourth Review }\end{array}$ & $3,309,000,000$ & 263 \\
\hline Fifth Review & March 15, 2012 & $\begin{array}{l}\text { Observance of end-December } 2011 \text { performance criteria, completion of } \\
\text { Fifth Review }\end{array}$ & $2,786,000,000$ & 222 \\
\hline Sixth Review & June 15, 2012 & $\begin{array}{l}\text { Observance of end-March } 2012 \text { performance criteria, completion of Sixth } \\
\text { Review }\end{array}$ & $1,191,000,000$ & 95 \\
\hline Seventh Review & September 5, 2012 & $\begin{array}{l}\text { Observance of end-June } 2012 \text { performance criteria, completion of } \\
\text { Seventh Review }\end{array}$ & $758,000,000$ & 60 \\
\hline Eight Review & December 12, 2012 & $\begin{array}{l}\text { Observance of end-September } 2012 \text { performance criteria, completion of } \\
\text { Eight Review }\end{array}$ & $758,000,000$ & 60 \\
\hline Ninth Review & March 15, 2013 & $\begin{array}{l}\text { Observance of end-December } 2012 \text { performance criteria, completion of } \\
\text { Ninth Review }\end{array}$ & $831,000,000$ & 66 \\
\hline Tenth Review & June 15, 2013 & $\begin{array}{l}\text { Observance of end-March } 2013 \text { performance criteria, completion of } \\
\text { Tenth Review }\end{array}$ & $831,000,000$ & 66 \\
\hline Eleventh Review & September 15, 2013 & $\begin{array}{l}\text { Observance of end-June } 2013 \text { performance criteria, completion of } \\
\text { Eleventh Review }\end{array}$ & $681,000,000$ & 54 \\
\hline Twelth Review & November 15, 2013 & $\begin{array}{l}\text { Observance of end-September } 2013 \text { performance criteria, completion of } \\
\text { Twelth Review }\end{array}$ & $579,374,800$ & 46 \\
\hline Total & & & $19,465,800,000$ & 1,548 \\
\hline
\end{tabular}

Source: IMF staff projections. 
Table 10. Ireland. Indicators of Fund Credit, 2010-23 1/ (In millions of SDR)

\begin{tabular}{|c|c|c|c|c|c|c|c|c|c|c|c|c|c|c|}
\hline & 2010 & 2011 & 2012 & 2013 & 2014 & 2015 & 2016 & 2017 & 2018 & 2019 & 2020 & 2021 & 2022 & 2023 \\
\hline \multicolumn{15}{|l|}{ Fund credit } \\
\hline Disbursement & - & 11,050 & 5,493 & 2,922 & - & - & - & - & - & - & - & - & - & - \\
\hline Stock 2/ & - & 11,050 & 16,543 & 19,466 & 19,466 & 18,931 & 16,757 & 13,862 & 10,617 & 7,373 & 4,129 & 1,420 & 349 & - \\
\hline Obligations & - & 109 & 236 & 473 & 643 & 1,209 & 2,801 & 3,426 & 3,652 & 3,520 & 3,388 & 2,748 & 1,083 & 351 \\
\hline Repurchase & - & - & - & - & - & 535 & 2,173 & 2,896 & 3,244 & 3,244 & 3,244 & 2,709 & 1,071 & 349 \\
\hline Charges & - & 109 & 236 & 473 & 643 & 674 & 628 & 530 & 407 & 275 & 144 & 39 & 12 & 3 \\
\hline \multicolumn{15}{|l|}{ Stock of Fund credit } \\
\hline In percent of quota & - & 879 & 1,315 & 1,548 & 1,548 & 1,505 & 1,332 & 1,102 & 844 & 586 & 328 & 113 & 28 & - \\
\hline In percent of GDP & - & 7.9 & 12.3 & 14.3 & 13.8 & 12.9 & 11.0 & 8.7 & 6.4 & 4.3 & 2.3 & 0.8 & 0.2 & - \\
\hline In percent of exports of goods and services & - & 7.5 & 11.4 & 13.0 & 12.4 & 11.4 & 9.6 & 7.5 & 5.5 & 3.7 & 2.0 & 0.7 & 0.2 & - \\
\hline \multicolumn{15}{|l|}{ Obligations to the Fund } \\
\hline In percent of quota & - & 9 & 19 & 38 & 51 & 96 & 223 & 272 & 290 & 280 & 269 & 218 & 86 & 28 \\
\hline In percent of GDP & - & 0.1 & 0.2 & 0.3 & 0.5 & 0.8 & 1.8 & 2.2 & 2.2 & 2.0 & 1.9 & 1.5 & 0.6 & 0.2 \\
\hline In percent of exports of goods and services & - & 0.1 & 0.2 & 0.3 & 0.4 & 0.7 & 1.6 & 1.9 & 1.9 & 1.8 & 1.6 & 1.3 & 0.5 & 0.1 \\
\hline
\end{tabular}

Source: IMF staff estimates.

1/ Calculated based on existing credit and full disbursements of the prospective available amounts under the extended arrangement under the Extended Fund Facility.

2/ End of period. 


\section{ANNEX I. DEBT SUSTAINABILITY ANALYSIS}

This Annex presents the public and external debt sustainability analysis based on staff's medium-term macroeconomic framework and the Irish authorities' fiscal consolidation plan.

\section{General Government Debt}

\section{Plans to maintain a higher cash buffer raise the gross debt trajectory while} leaving net debt unchanged. Ireland's projected market issuance has been revised up by about $€ 6.2$ billion (3.8 percent of GDP) in 2013 to ensure a comfortable cash buffer when exiting the EU-IMF program, on the order of $€ 19$ billion (12 percent of GDP) at end 2013, which is about one year of funding requirements. As result, gross debt is projected to peak at 122 percent of GDP in 2013 - up from 119 percent at the seventh review-while net debt is little changed.

2. Under the baseline macroeconomic projection, the planned fiscal adjustment will put Ireland's debt ratio on a declining path from 2014. Ireland's primary deficit is programmed to fall below its debt stabilizing threshold in 2014. Automatic debt dynamics arising from the interest rate-growth differential will add some two percentage points per year to the debt ratio in 2012-13, before stronger growth takes hold from 2015.

Subsequently, the interest rate-growth differential averages 0.6 percent over 2015-21, at the lower end of the range for advanced economies. ${ }^{1}$ Gross general government debt is projected to fall to 97 percent of GDP by 2021.

3. Lower economic growth remains the principal risk to debt sustainability. If real GDP growth were to stagnate at $1 / 2$ percent per year in the medium term, the debt reducing effect would decrease to 0.6 percentage points per annum, from 2.8 percentage points in the baseline. At this level, debt would be on an unsustainable path to 146 percent of GDP by 2021. In addition, stagnant growth may add to debt from higher bank restructuring costs and slower fiscal consolidation.

4. Contingent liabilities could cause debt to increase. The government has a range of explicit guarantees, which continue to decline as NAMA bonds mature and the ELG scheme is phased out. It owns NAMA and IBRC, which are resolving loan portfolios with heavy Ireland: Contingent Liabilities (in percent of projected 2012 GDP)

\begin{tabular}{lr}
\hline Senior NAMA bonds & 17.6 \\
Guarantees for Emergency Liquidity Assistance & 9.5 \\
Other Bank Liabilities covered by Eligible Liability Scheme & 13.6 \\
Total & $\mathbf{4 0 . 7}$ \\
\hline Source: Irish authorities and IMF staff calculations &
\end{tabular}
exposure to Irish and U.K. propery markets. It is also exposed to the potential for larger loan

\footnotetext{
${ }^{1}$ See Escolano, Shabunina, and Woo (2011). "The Puzzle of Persistently Negative Interest Rate-Growth Differentials: Financial Repression or Income Catch-Up?” IMF Working Paper 11/260.
} 
losses in the financial system, including the domestic banks if their current capital buffers were exhausted.

\section{Quantifying these potential contingent liabilities is subject to significant} uncertainty. IBRC management expects that resolution costs could be $€ 25$ billion, as opposed to the $€ 29$ billion to $€ 34$ billion previously estimated, while noting this is highly contingent on developments in UK and Irish property markets. IBRC also has a capital buffer that would first absorb any shortfall, with the tier 1 capital ratio as of end June estimated at 13.6 percent. NAMA is confident it will at least break even if Irish property prices were to recover back to end-2009 levels by $2020 .^{2}$ Yet in a scenario with prolonged weak growth with no recovery in asset prices, and potentially a further decline, losses could be incurred, and further losses on bank loans, beyond those in the PCAR 2011 stress test, could also arise. Drawing on the difference between loan loss projections between the base and stress scenario in PCAR 2011, allowing for overall impact on the order of 10 percent of GDP - including NAMA and IBRC — appears reasonably conservative.

6. Interest rate shocks remain a less powerful risk. The baseline is built on projections of unchanged, elevated interest rates, and have not taken into account the recent declines in spreads, thus including a safety margin. In the medium term, Ireland is shielded from increasing interest rates given its high share of fixed rate and official borrowing. For example, a 200 basis points upward shift of the interest rate on new borrowing would increase the effective interest on Ireland's stock of public debt by 96 basis points by 2019, resulting in a slower decline of the debt ratio. Only a permanent shock exceeding about 450 basis points on all short-term and new lending would prevent Ireland's from lowering its debt in the long run.

\section{Debt reductions from asset sales, including the divestments of state participation}

in the banking sector, are an upside risk. Current assumptions do not incorporate proceeds from state asset disposals of up to $€ 3$ billion ( 2 percent of GDP), at least half of which are to be used for debt reduction. At the same time, no allowance for potential additional costs from the restructuring and resolution of credit unions is made beyond $€ 0.5$ billion, as these costs are still being quantified and are not expected to be large in macroeconomic terms. ${ }^{3}$ No allowance for ESM equity investments in the banking sector or other bank equity divestments is made.

\footnotetext{
${ }^{2}$ Owing to a 20 percent decline in property values during 2010-11, NAMA has a cumulative impairment provision of $€ 2.88$ billion through June 2012. On the other hand, at end-2011, NAMA had a net discounted unrealized surplus of $€ 1.82$ billion stemming from debtor cash flows, which has not been recognized in the income statement, implying a potential net loss of about $€ 1$ billion.

${ }^{3}$ This is the sum of $€ 0.25$ billion already placed in the Resolution Fund, and $€ 0.25$ billion expected to be placed in the Credit Union Fund by end 2012.
} 


\section{External Debt}

8. The external debt of the non-IFSC sector increased in the second quarter of 2012 and remains high, though below the end-2011 levels. ${ }^{4}$ At the end of Q2 2012, total external non-IFSC debt stood at around 307 percent of GDP, down from 322 percent of GDP recorded last year but above the 300 percent recorded in Q1. About one third of this quarterly increase represented a rise in the official debt of the government as the authorities continued to draw funds under the EU-IMF program. External debt of the central bank rose as well due to an increase in Target 2 liabilities. At the same time, financial institutions continued to deleverage, reducing their external debt and partially offsetting the rise in the official debt.

\section{By 2017, external debt is expected to fall to 219 percent of GDP, though} significant risks surround this forecast. Lackluster recovery remains the main risk: a macroeconomic scenario at historical averages would fail to stabilize the debt-to-GDP ratio in the next five years, bringing the external debt to around 316 percent of percent of GDP in 2017. A permanent $1 / 2$ standard deviation shock to growth, implying a renewed recession in 2013 and sluggish growth thereafter, would raise the debt-to-GDP ratio to 247 percent of GDP in the medium term, around 28 percentage points above the baseline. A permanent $1 / 2$ standard deviation shock to the non-IFSC current account (excluding interest payments) would raise the medium-term debt ratio by around 20 percentage points compared to the baseline. A standard combined shock of $1 / 4$ of the standard deviation applied to the current account, interest rates, and the GDP growth rate would increase the medium-term debt to 248 percent of GDP.

\section{Total external debt including the IFSC remains very high, at around} 1,040 percent of GDP at the end of Q22012. Although external debt has risen compared to the first quarter, it remains below the end-2011 level of 1,075 percent of GDP. In addition to a reduction in the non-IFSC debt in the first half of the year, the IFSC sector has reduced its gross external debt by 22 percentage points of GDP. The net international investment position has

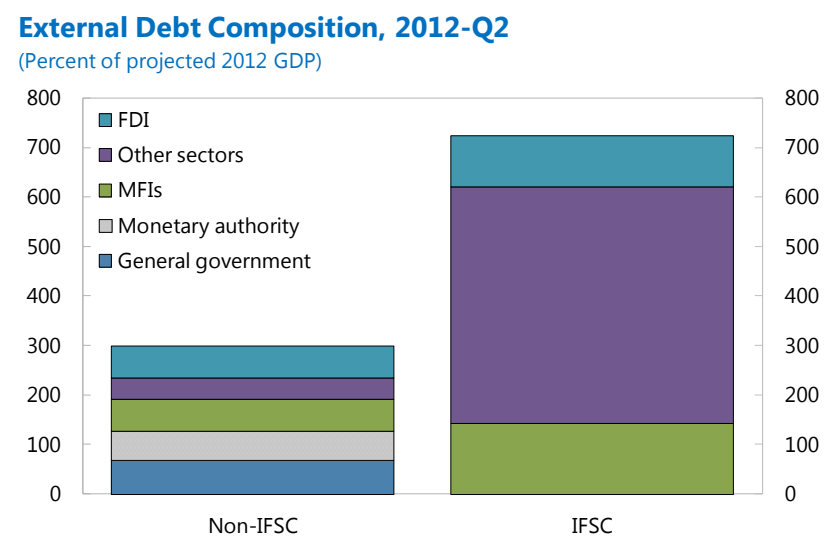

Sources: Central Statistics Office Ireland; and IMF staff calculations. fallen to 94 percent of GDP due to an improvement in the external position of both the IFSC and the non-IFSC sector.

\footnotetext{
${ }^{4}$ The discussion excludes debt incurred by the International Financial Services Centre (IFSC), which comprises of a broad range of financial institutions including banks, insurance companies, investment funds, and other support firms, which provide financial services mostly to non-residents.
} 
Ireland: Net International Investment Position

(In percent of GDP)

\begin{tabular}{lrrrrrrrr}
\hline & 2005 & 2006 & 2007 & 2008 & 2009 & 2010 & 2011 & Q2-2012 \\
\hline Assets & 1,031 & 1,132 & 1,203 & 1,276 & 1,503 & 1,697 & 1687 & 1714 \\
Direct investment abroad & 54 & 52 & 54 & 68 & 127 & 163 & 153 & 161 \\
Portfolio investment abroad & 615 & 692 & 709 & 707 & 839 & 932 & 901 & 942 \\
Other investment abroad & 362 & 388 & 439 & 501 & 536 & 602 & 633 & 611 \\
Reserve assets & 0 & 0 & 0 & 0 & 1 & 1 & 1 & 1 \\
Liabilities & 1,056 & 1,137 & 1,222 & 1,353 & 1,596 & 1,786 & 1783 & 1808 \\
Direct investment to Ireland & 85 & 67 & 73 & 76 & 108 & 137 & 122 & 131 \\
Portfolio investment to Ireland & 629 & 689 & 705 & 716 & 908 & 1,066 & 1085 & 1118 \\
Other investment to Ireland & 342 & 382 & 444 & 561 & 580 & 583 & 576 & 559 \\
Net investment position & -25 & -5 & -20 & -76 & -93 & -89 & -96 & -94 \\
$\quad$ Direct investment, net & -31 & -15 & -19 & -8 & 19 & 26 & 30 & 30 \\
Portfolio investment, net & -15 & 4 & 5 & -9 & -69 & -134 & -184 & -177 \\
Other investment, net 1/ & 20 & 6 & -5 & -60 & -44 & 18 & 57 & 52 \\
Reserve assets & 0 & 0 & 0 & 0 & 1 & 1 & 1 & 1 \\
Memorandum items & & & & & & & & 15 \\
$\quad$ Net IIP of the IFSC & & & & & & & -111 & -98 \\
Net IIP of the non-IFSC & & & & & & &
\end{tabular}

Source: Central Statistics Office.

$1 /$ Includes valuation changes and errors and omissions. 
Annex I Table 1. Ireland: Public Sector Debt Sustainability Framework, 2007-2021 1/

(In percent of GDP, unless otherwise indicated)

\begin{tabular}{|c|c|c|c|c|c|c|c|c|c|c|c|c|c|c|c|c|}
\hline & \multicolumn{5}{|c|}{ Actual } & \multicolumn{10}{|c|}{ Projections } & \multirow{3}{*}{$\begin{array}{l}\text { Debt-stabilizing } \\
\text { primary } \\
\text { balance 11/ }\end{array}$} \\
\hline & 2007 & 2008 & 2009 & 2010 & 2011 & 2012 & 2013 & 2014 & 2015 & 2016 & 2017 & 2018 & 2019 & 2020 & 2021 & \\
\hline 1 Baseline: General government debt & 248 & 44.2 & 652 & 922 & 1065 & 1183 & 1225 & 1217 & 1180 & 1153 & 121 & 1085 & 1046 & 1009 & 974 & \\
\hline & & & & & & & & & & & & & & & & \\
\hline & 0.1 & 19.4 & 20.9 & 27.0 & 14.3 & 11.8 & 4.2 & -0.8 & -3.7 & -2.7 & -3.2 & -3.6 & -3.9 & -3.7 & -3.5 & \\
\hline 3 Identified debt-creating flows $(4+7+12)$ & -1.6 & 8.7 & 23.9 & 35.0 & 18.2 & 6.1 & 4.7 & 0.7 & -2.3 & -2.9 & -3.2 & -3.5 & -3.8 & -3.7 & -3.5 & \\
\hline \multirow{2}{*}{$\begin{array}{l}4 \quad \text { Primary deficit } \\
5\end{array}$} & -1.1 & 6.0 & 9.7 & 7.6 & 5.9 & 4.4 & 1.8 & -0.6 & -2.7 & -3.3 & -3.8 & -4.1 & -4.6 & -4.5 & -4.4 & \\
\hline & 36.3 & 35.0 & 33.7 & 34.0 & 34.1 & 34.2 & 34.5 & 34.8 & 34.6 & 34.2 & 34.0 & 34.0 & 34.0 & 34.0 & 34.0 & \\
\hline \multirow{2}{*}{6 Primary (noninterest) expenditure 2/ } & 35.1 & 40.9 & 43.4 & 41.6 & 40.0 & 38.6 & 36.3 & 34.2 & 31.9 & 30.9 & 30.2 & 29.9 & 29.4 & 29.6 & 29.6 & \\
\hline & -0.5 & 2.8 & 7.4 & 4.9 & 1.8 & 1.8 & 2.9 & 1.3 & 0.4 & 0.3 & 0.6 & 0.6 & 0.8 & 0.8 & 0.9 & \\
\hline 8 Contribution from interest rate/growth differential $4 /$ & -0.5 & 2.8 & 7.4 & 4.9 & 1.8 & 1.8 & 2.9 & 1.3 & 0.4 & 0.3 & 0.6 & 0.6 & 0.8 & 0.8 & 0.9 & \\
\hline 9 Of which contribution from real interest rate & 0.7 & 2.0 & 3.9 & 3.1 & 3.1 & 2.2 & 4.1 & 3.9 & 3.7 & 3.6 & 3.8 & 3.3 & 3.4 & 3.3 & 3.3 & \\
\hline Of which contribution from real GDP growth & -1.2 & 0.8 & 3.5 & 1.7 & -1.3 & -0.4 & -1.2 & -2.6 & -3.2 & -3.2 & -3.2 & -2.7 & -2.6 & -2.5 & -2.4 & \\
\hline \multirow{2}{*}{$\begin{array}{l}\text { Contribution from exchange rate depreciation 5/ } \\
\text { Other identified debt-creating flows }\end{array}$} & 0.0 & 0.0 & 0.0 & 0.0 & 0.0 & 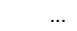 & & & & 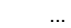 & - & $\ldots$ & & & & \\
\hline & 0.0 & 0.0 & 6.8 & 22.5 & 10.6 & 0.0 & 0.0 & 0.0 & 0.0 & 0.0 & 0.0 & 0.0 & 0.0 & 0.0 & 0.0 & \\
\hline $\begin{array}{ll}2 & \text { Other identified debt-creating flows } \\
3 & \text { Privatization receipts (negative) }\end{array}$ & 0.0 & 0.0 & 0.0 & 0.0 & 0.0 & 0.0 & 0.0 & 0.0 & 0.0 & 0.0 & 0.0 & 0.0 & 0.0 & 0.0 & 0.0 & \\
\hline $4 \quad$ Recognition of implicit or contingent liabilities & 0.0 & 0.0 & 0.0 & 0.0 & 0.0 & 0.0 & 0.0 & 0.0 & 0.0 & 0.0 & 0.0 & 0.0 & 0.0 & 0.0 & 0.0 & \\
\hline \multirow{2}{*}{$\begin{array}{l}5 \text { Other (bank recapitalization) } 6 / \\
6 \text { Residual, including asset changes (2-3) 7/ }\end{array}$} & 0.0 & 0.0 & 6.8 & 22.5 & 10.6 & 0.0 & 0.0 & 0.0 & 0.0 & 0.0 & 0.0 & 0.0 & 0.0 & 0.0 & 0.0 & \\
\hline & 1.7 & 10.7 & -3.0 & -7.9 & -4.0 & 5.7 & -0.5 & -1.5 & -1.4 & 0.2 & 0.0 & -0.1 & -0.1 & 0.0 & 0.0 & \\
\hline General government debt-to-revenue ratio & 68.5 & 126.5 & 193.1 & 271.0 & 312.0 & 346.0 & 355.5 & 350.0 & 341.2 & 337.4 & 329.4 & 318.9 & 307.4 & 296.6 & 286.3 & \\
\hline \multirow{2}{*}{$\begin{array}{l}\text { Scenario with key variables at their historical averages 9/ } \\
\text { Scenario with no policy change (constant primary balance) in 2012-2021 }\end{array}$} & & & & & & 118.3 & 120.7 & 122.1 & 123.7 & 126.8 & 129.8 & 132.7 & 135.7 & 138.7 & 141.8 & 1.5 \\
\hline & & & & & & 118.3 & 125.1 & 129.3 & 132.7 & 137.6 & 142.7 & 147.8 & 153.1 & 158.6 & 164.4 & 1.4 \\
\hline \multicolumn{17}{|l|}{ Key Macroeconomic and Fiscal Assumptions Underlying Baseline } \\
\hline Real GDP growth (in percent) & 5.2 & -3.0 & -7.0 & -2.6 & 1.4 & 0.4 & 1.1 & 2.2 & 2.8 & 2.9 & 2.9 & 2.5 & 2.5 & 2.5 & 2.5 & \\
\hline \multirow{2}{*}{$\begin{array}{l}\text { Real GDP growth (in percent) } \\
\text { Average nominal interest rate on public debt (in percent) } 10 /\end{array}$} & 4.5 & 5.3 & 4.1 & 4.7 & 3.6 & 3.8 & 4.9 & 4.8 & 4.8 & 4.8 & 5.0 & 4.7 & 4.9 & 4.9 & 5.0 & \\
\hline & 3.2 & 7.6 & 8.2 & 4.7 & 3.4 & 2.1 & 3.6 & 3.4 & 3.2 & 3.2 & 3.5 & 3.1 & 3.3 & 3.3 & 3.4 & \\
\hline $\begin{array}{l}\text { Average real interest rate (nominal rate minus change in GDP detlator, in percent) } \\
\text { Nominal appreciation (increase in US dollar value of local currency, in percent) }\end{array}$ & 7.4 & 0.0 & -5.4 & -5.1 & $\begin{array}{l}-0.4 \\
-0.3\end{array}$ & & & & & & & & & & & \\
\hline \multirow{2}{*}{$\begin{array}{l}\text { Infl } \\
\mathrm{Gr}\end{array}$} & 1.3 & -2.3 & -4.1 & 0.0 & 0.2 & 1.6 & 1.3 & 1.4 & 1.6 & 1.6 & 1.6 & 1.6 & 1.6 & 1.6 & 1.6 & \\
\hline & 14.2 & 13.0 & -1.4 & -6.7 & -2.4 & -3.1 & -5.0 & -3.7 & -4.0 & -0.3 & 0.4 & 1.6 & 0.9 & 2.9 & 2.8 & \\
\hline Primary deficit 21 & -1.1 & 6.0 & 9.7 & 7.6 & 5.9 & 4.4 & 1.8 & -0.6 & -2.7 & -3.3 & -3.8 & -4.1 & -4.6 & -4.5 & -4.4 & \\
\hline
\end{tabular}

$1 /$ General government gross debt. The projections include Fund and EU disbursements. Government-guaranteed NAMA bonds are excluded, based on Eurostat guidance. From 2018, no policy change is assumed

/ Excluding bank support costs.

3/ Derived as $[(r-\pi(1+g)-g+\alpha \varepsilon(1+r)](1+g+\pi+g \pi))$ times previous period debt ratio, with $r=$ interest rate; $\pi=$ growth rate of GDP deflator; $g=$ real GDP growth rate; $\alpha=$ share of foreign-currency denominated debt; and $\mathrm{e}=$ nominal exchange rate

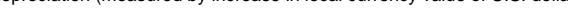

作

作

8/ Defined as public sector deficit, plus amortization of medium and long-term public sector debt and short-term debt at end of previous period, and bank recapitalization costs.

9/ The key variables include real GDP growth; real interest rate; and primary balance in percent of GDP.

10/ Derived as nominal interest expendilure divided by previous period debt stock.

11/ Assumes that key variables (real GDP growth, real interest rate, and other identified debt-creating flows) remain at the level of the last projection year. 
Annex I Table 2. Ireland: External Debt Sustainability Framework, 2007-2017

(In percent of GDP, unless otherwise indicated)

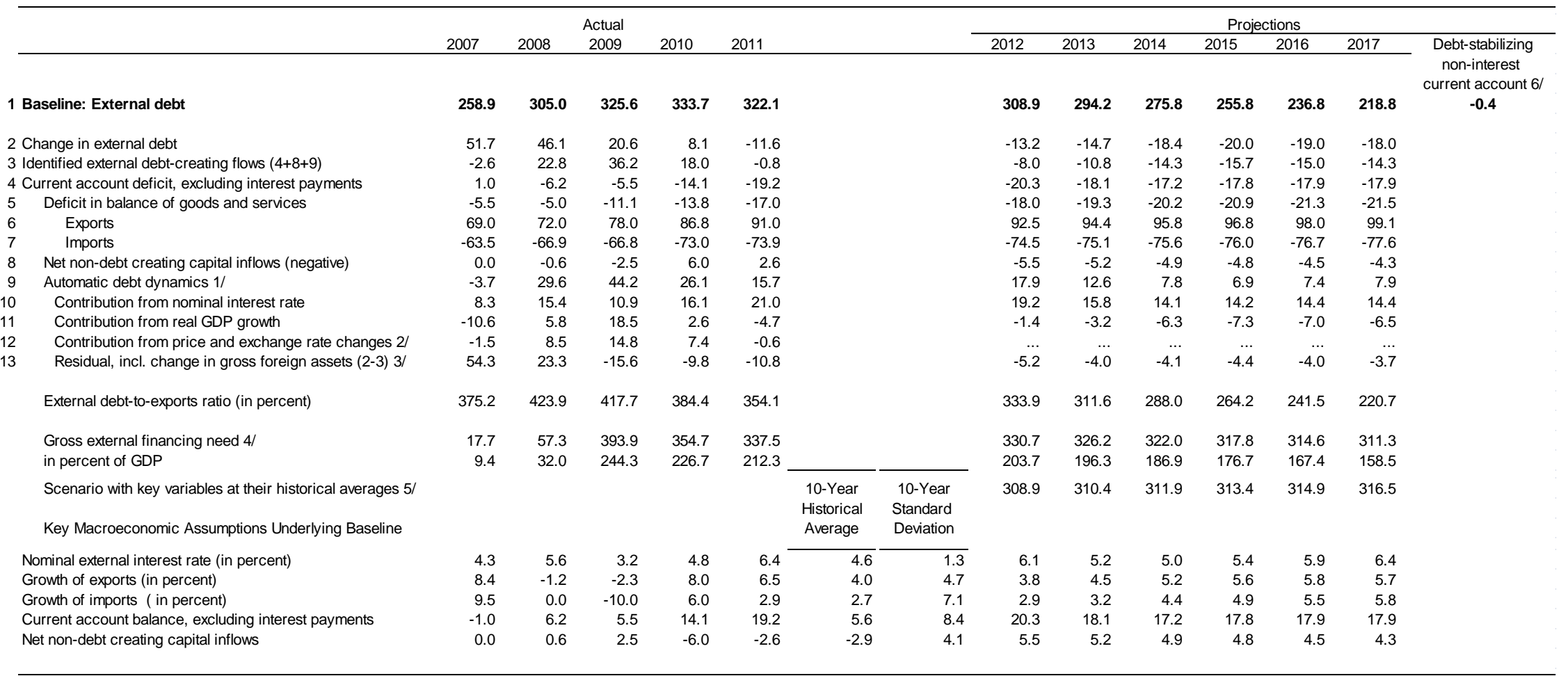

$1 /$ Derived as $[r-g-r(1+g)+e a(1+r)](1+g+r+g r)$ times previous period debt stock, with $r=$ nominal effective interest rate on external debt; $r=$ change in domestic GDP deflator in US dollar terms, $g=$ real GDP growth rate,

$\mathrm{e}=$ nominal appreciation (increase in dollar value of domestic currency), and $\mathrm{a}=$ share of domestic-currency denominated debt in total external debt

$2 /$ The contribution from price and exchange rate changes is defined as $[-r(1+g)+e a(1+r)](1+g+r+g r)$ times previous period debt stock. $r$ increases with an appreciating domestic currency (e $>0)$ and rising inflation $($ based on GDP deflator). $3 /$ For projection, line includes the impact of price and exchange rate changes.

4/ Defined as current account deficit, plus amortization on medium- and long-term debt, plus short-term debt at end of previous period.

variables include real GDP growth: nominal interest rate; dollar deflator growth; and both non-interest current account and non-debt inflows in percent of GDP.

(the

of the last projection year. 
Annex I Figure 1. Ireland: Public Debt Sustainability: Bound Tests 1/ (General government debt in percent of GDP)

Baseline and historical scenarios
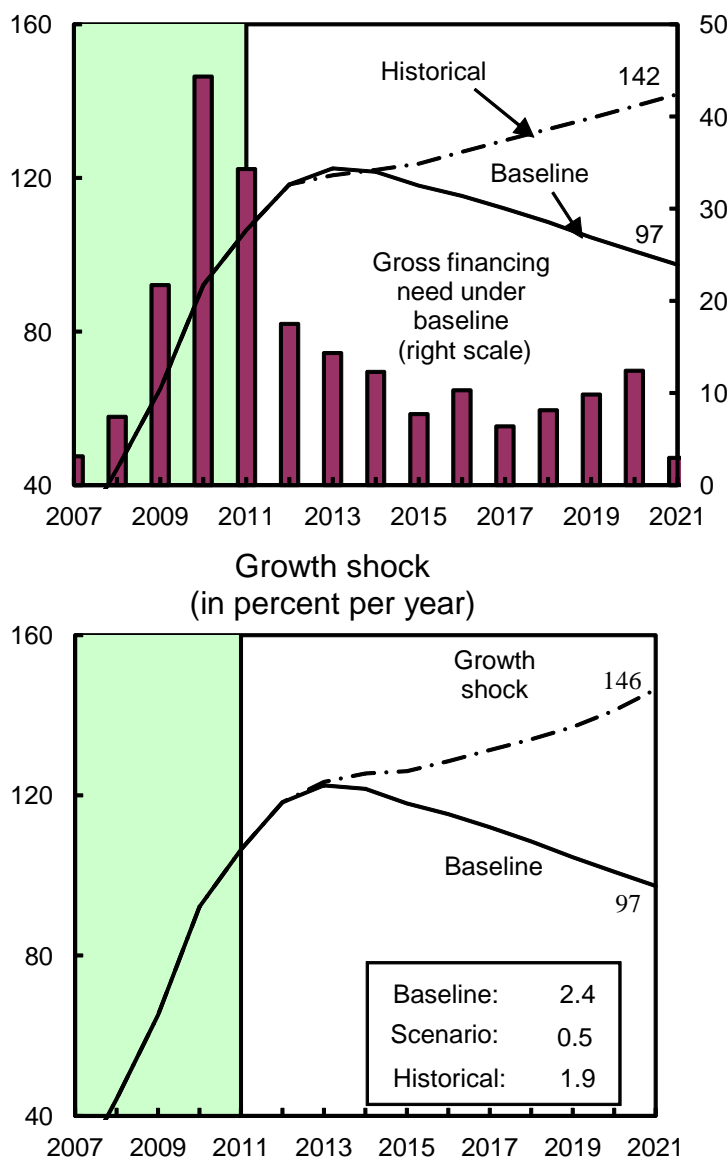

Combined shock 2/

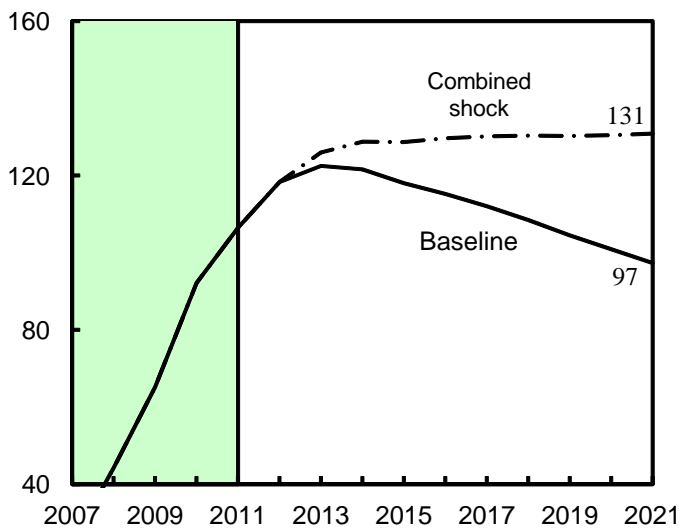

Interest rate shock (in percent)

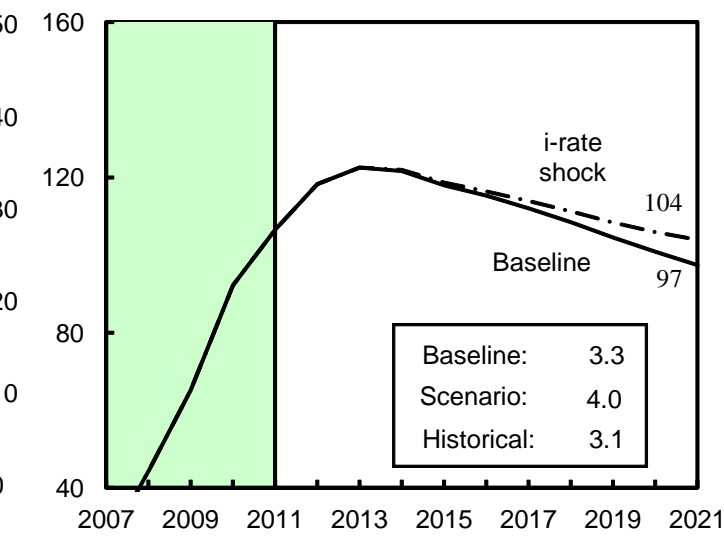

Primary balance shock and no policy change scenario (constant primary balance)

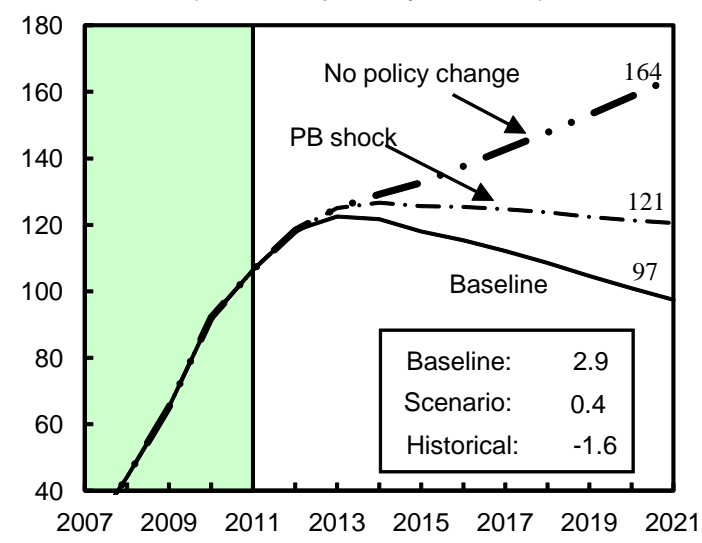

Contingent liabilities shocks 3/

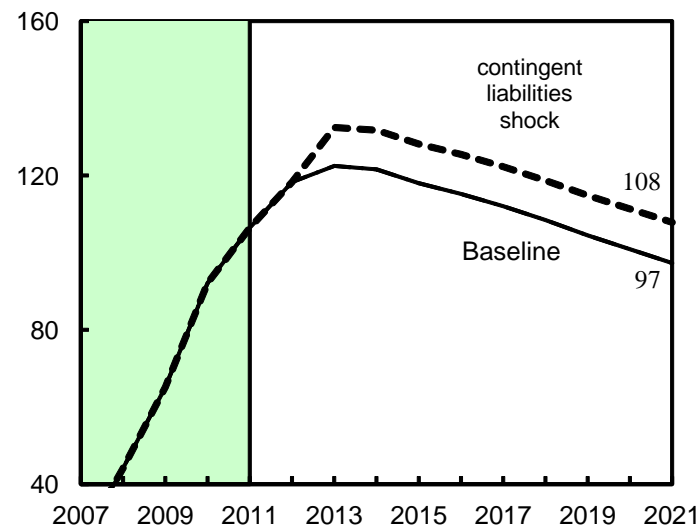

Sources: International Monetary Fund, country desk data, and staff estimates.

$1 /$ Shaded areas represent actual data. The interest rate shock is a permanent 200 basis point shock applied to short-term debt and new market lending, the growth shock is a stagnation of growth at 0.5 percent per annum, and the primary balance shock is a one-half standard deviation shock. Figures in the boxes represent average projections for the respective variables in the baseline and scenario being presented. Ten-year historical average for the variable is also shown.

2/ Permanent $1 / 4$ standard deviation shocks applied to the growth rate , interest rate, and primary balance.

3/ Illustrative one-time 10 percent of GDP shock to contingent liabilities in 2013. 
Annex I Figure 2. Ireland: External Debt Sustainability: Bound Tests 1/ 2/ (External debt in percent of GDP)

Baseline and historical scenarios

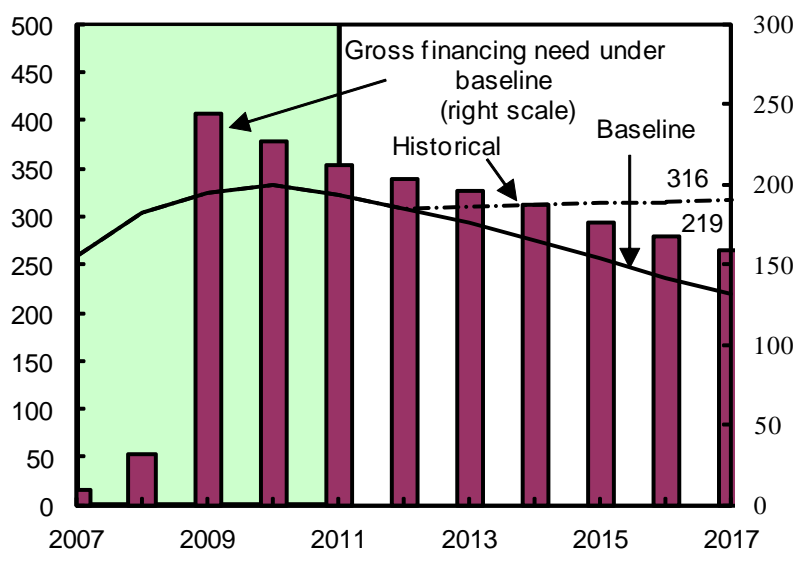

Growth shock (in percent per year)

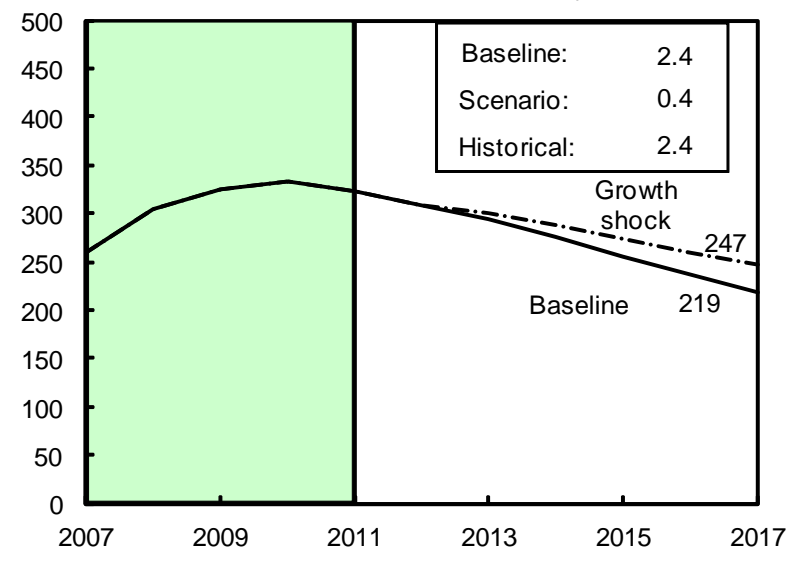

Combined shock $3 /$

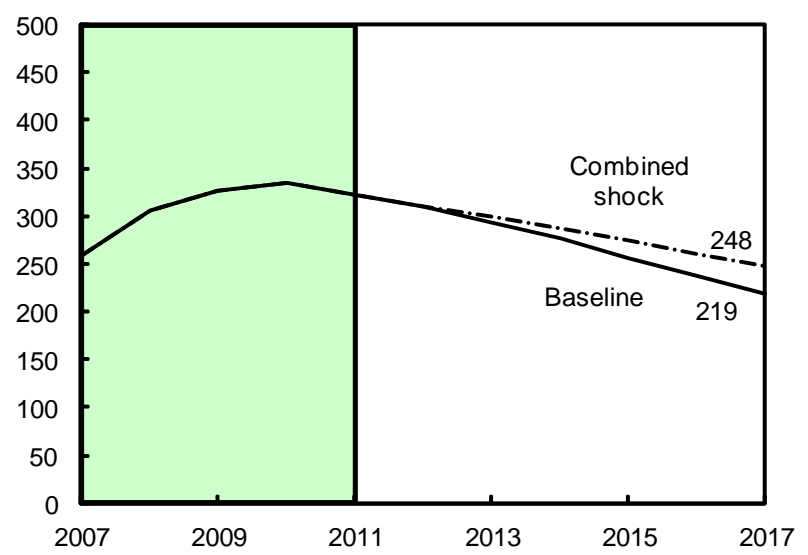

Interest rate shock (in percent)

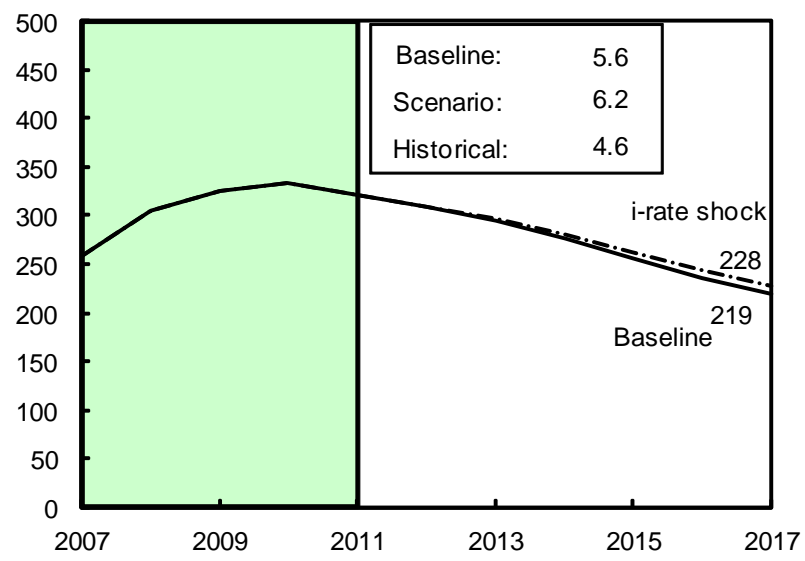

Non-interest current account shock (in percent of GDP)

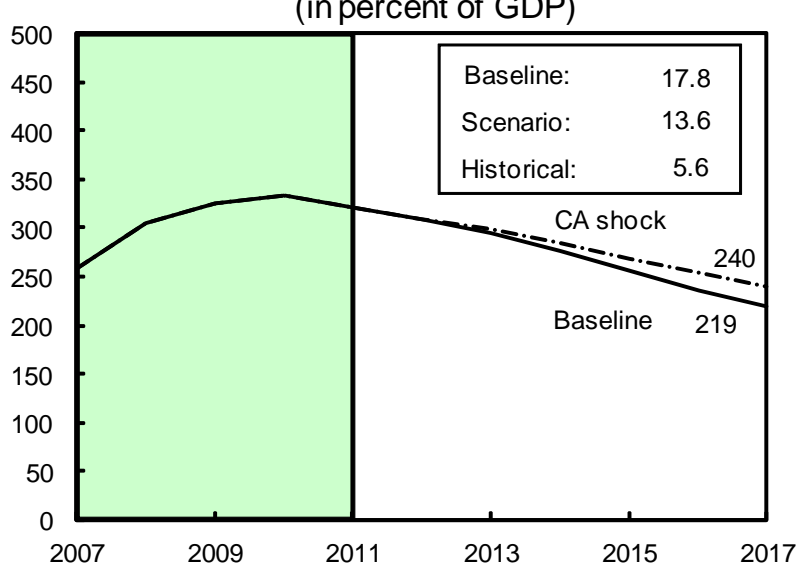

Real depreciation shock 4/

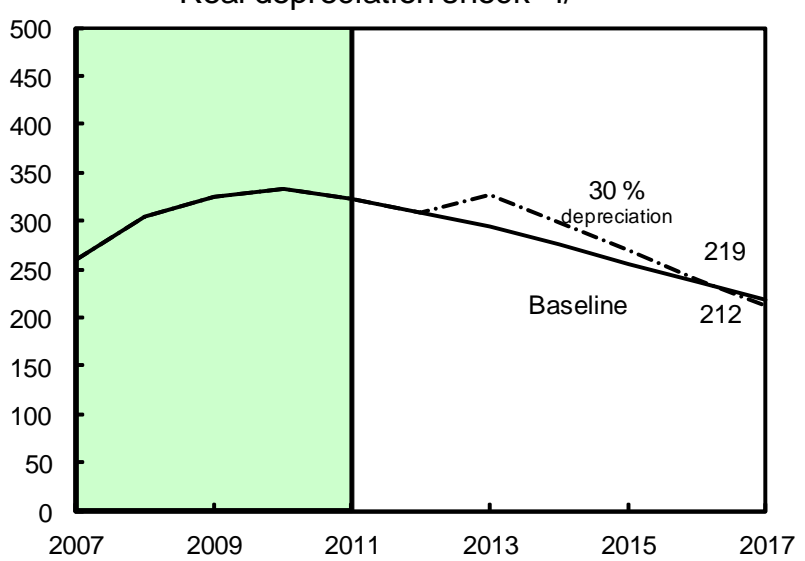

Sources: International Monetary Fund, Ireland desk data, and staff estimates.

$1 /$ Shaded areas represent actual data. Individual shocks are permanent one-half standard deviation shocks. Figures in the boxes represent average projections for the respective variables in the baseline and scenario being presented. Tenyear historical average for the variable is also shown.

$2 /$ For historical scenarios, the historical averages are calculated over the ten-year period, and the information is used to project debt dynamics five years ahead.

3/ Permanent 1/4 standard deviation shocks applied to real interest rate, growth rate, and current account balance.

4/ One-time real depreciation of 30 percent occurs in 2013. 


\section{ANNEX II. Fund RELATIONS \\ (As of October 31, 2012)}

I. Membership Status: Joined August 8, 1957; Article VIII

II. General Resources Account:

Quota

Fund holdings of currency

Reserve position in Fund

III. SDR Department:

Net cumulative allocation

Holdings

IV. Outstanding Purchases and Loans:

Extended Arrangements

$\begin{array}{cc}\text { SDR Million } & \text { Percent of Quota } \\ 1,257.60 & 100.00 \\ 16,784.46 & 1,334.64 \\ 258.57 & 20.56\end{array}$

SDR Million Percent of Allocation

775.42

100.00

646.54

83.38

V. Financial Arrangements:

$\begin{array}{lcccc}\text { Type } & \begin{array}{c}\text { Approval } \\ \text { Date }\end{array} & \begin{array}{c}\text { Expiration } \\ \text { Date }\end{array} & \begin{array}{c}\text { Amount Approved } \\ \text { (SDR million) }\end{array} & \begin{array}{c}\text { Amount Drawn } \\ \text { (SDR million) }\end{array} \\ \text { EFF } & 12 / 16 / 10 & 12 / 15 / 13 & 19,465.80 & 15,785.43\end{array}$

VI. Projected Payments to the Fund (SDR million; based on existing use of resources and present holdings of SDRs):

$\begin{array}{lrrrrr} & \underline{2012} & \underline{2013} & \underline{2014} & \underline{2015} & \underline{2016} \\ \text { Principal } & & & & 535.20 & 2,173.15 \\ \text { Charges/Interest } & 99.52 & 412.25 & 506.89 & 527.56 & 481.08 \\ \text { Total } & 99.52 & 412.25 & 506.89 & 1,062.76 & 2,654.23\end{array}$

\section{Exchange Rate Arrangement and Exchange Restrictions:}

Ireland's currency is the euro, which floats freely and independently against other currencies. Ireland has accepted the obligations of Article VIII, Sections 2, 3, and 4, and maintains an exchange system free of restrictions on payments and transfers for current international transactions, other than restrictions notified to the Fund under Decision No. 144 (52/51).

\section{Safeguards Assessment:}

The safeguards assessment of the Central Bank of Ireland (CBI) was finalized in March 2011. The safeguards assessment of the Central Bank of Ireland (CBI) found that the 
CBI has a relatively strong safeguards framework in place. Its financial statements are audited in accordance with international standards and published. Governance and control systems adhere to good practices. The assessment recommended measures to address heightened risks emanating from the financial crisis, notably liquidity lending, and to improve transparency. Recommendations were also made to strengthen the de-jure autonomy of the central bank. Progress has been made in implementing these recommendations: the CBI has strengthened internal governance and control procedures for ELA; brought forward the publication dates for its audited financial accounts; clarified its accounting framework for areas not covered by ECB guidelines; and formally approved revised investment guidelines. The CBI and DoF are considering how to strengthen the arrangements for financial autonomy of the CBI, which may require changes to central bank legislation and changes in other related regulations, which would be prepared in consultation with the ECB.

\section{Article IV Consultations:}

The last Article IV consultation was concluded on September 10, 2012 (IMF Country Report No. 12/284). Article IV consultations with Ireland are on the 24-month cycle.

\section{Eight Review Under the Extended Arrangement:}

Discussions were held in Dublin during October 16-25, 2012. The IMF team comprised Craig Beaumont (head), Alexandre Chailloux, Jochen Andritzky, and Emilia Jurzyk (all EUR); S.M. Ali Abbas (FAD); Maike Luedersen (LEG); Michael Moore and Joaquin Gutierrez Garcia (both MCM), and Gavin Gray (SPR). Teams from the EC and ECB as well as Mary O'Dea and Peter McGoldrick from the Executive Director's office participated in the discussions. The mission met with the Minister for Finance, the Minister for Public Expenditure and Reform, the Governor of the Central Bank and the Deputy Governor for Financial Regulation, the Chief Executive of the National Treasury Management Agency, the Chief Executive of the National Asset Management Agency, and senior officials from these institutions. The mission also met with representatives of the Fiscal Council; the Department of Jobs, Enterprise and Innovation; the Department of Justice and Equality; the Department of Social Protection; Central Statistics Office; the Economic and Social Research Institute; banks and market analysts.

XI. Technical Assistance:

Department

STA

STA
Purpose

Balance of Payments Statistics

Monetary and Financial Statistics
Date

January 2011

January 2011

\section{Resident Representative:}

Mr. Peter Breuer assumed his post in September 2011. 


\section{Attachment I. Ireland: Letter of Intent}

Dublin, 29 November 2012

Ms. Christine Lagarde

Managing Director

International Monetary Fund

Washington, D.C. 20431

Dear Ms. Lagarde:

1. The Irish Government remains firmly committed to the programme, as illustrated by our continued strong performance in implementing the agreed policy frameworks and measures. This performance, and our preparation for Budget 2013, is against a backdrop of an increasingly adverse international economic environment. Nevertheless our government bond yields have fallen dramatically in recent months, reflecting our strong performance as well as certain positive developments in Europe, especially the euro area leaders' June 29 commitment to decouple the sovereign and banking debt issues and in this context to specifically examine the situation of the Irish financial sector with the view of improving the sustainability of Ireland's well-performing adjustment programme. The ECB's decision on Outright Monetary Transactions is another positive development. These improved market conditions enabled the launch of our first bond issue under the programme in late July and the renewal of regular Treasury bill auctions. As we enter the final year of our three year programme, we are now focusing on the measures necessary to successfully exit from the programme. Notwithstanding the external risks, our policy efforts are aimed at further deepening our access to market funding during 2013, in order to exit from reliance on official financing. Timely implementation of euro area leaders' commitments would greatly support the effectiveness of these efforts. We are sure that we can rely on the continued support of our external partners and fellow member states in this endeavour.

2. Once again, for the eighth review, we have met our commitments under the EU/IMF supported programme in terms of policy reforms as well as quantitative targets (MEFP Tables 1 and 2):

- The performance criterion for end-September 2012 on the cumulative Exchequer primary balance was met with a margin, as was the indicative target on the stock of Central Government net debt. The continuous performance criterion on nonaccumulation of external payment arrears has also been met.

- We published on September 28 the Credit Union Bill 2012, which strengthens the regulatory framework of credit unions including with regards to effective governance standards and prudential requirements (end-September structural benchmark). 
- We also issued on September 28 regulations to establish a levy across credit institutions to recoup over time costs of resolving vulnerable institutions (endSeptember structural benchmark).

3. Looking ahead, we have recently published our medium-term fiscal statement, confirming our adherence to the agreed fiscal targets for 2013-15. Notwithstanding the much weaker growth outlook, in Budget 2013, we are committed to meeting the previously agreed deficit ceiling of 7.5 percent of GDP, and will take durable, equitable and growth-friendly measures to achieve this target.

4. In the attached Memorandum of Economic and Financial Policies (MEFP), we set out in more detail our plans to further advance towards meeting the objectives laid out in our programme supported by the Extended Arrangement and by the EU. Based on the strength of these policies, and in light of our performance under the programme and our continued commitment, we request the completion of the eighth review under the Extended Arrangement. We also request that the eighth purchase in an amount equivalent to SDR 758 million becomes available at the time of completion of the review.

5. We continue to move towards the goal of fully regaining market access during 2013. The resumption of Treasury bill auctions and our initial bond issue are steps in this direction. We have also diversified our investor base through the issuance of long-term amortizing bonds targeted at domestic pension funds. We intend to maintain a strong cash buffer to support market confidence during this process of deepening market access, and propose to leave the phasing of purchases unchanged, with a total purchase amount of SDR 2,922 million in 2013.

6. We propose that quantitative performance criteria under the arrangement be established for end-March 2013, as set out in the attached MEFP (Table 3). As detailed in the MEFP, we also propose two new structural benchmarks - on requesting an external assessment of observance of the Basel Core Principles for Effective Banking Supervision (end-March 2013) and on undertaking a review of progress in addressing mortgage arrears (end-June 2013). The Technical Memorandum of Understanding (TMU) explains how programme targets are measured.

7. We are confident that the policies set forth in the Letters of Intent of 3 December 2010 and subsequent letters as well as this letter are adequate to achieve the objectives of our programme. At the same time, while we do not envisage that revisions will be needed, we stand ready to take any corrective actions that may become appropriate if circumstances change. As is standard under Fund-supported programmes, we will consult with the Fund on the adoption of such actions in advance in the event that revision of the policies contained in this Letter and the attached Memorandum becomes necessary, and at the same time consult with the European Commission and the ECB. 
8. This letter is being copied to Messrs. Draghi, Juncker, Rehn, and Shiarly.

Sincerely,

/s/

Michael Noonan, T.D.

Minister for Finance
Patrick Honohan

Governor of the Central Bank of Ireland 


\section{Attachment II. Ireland: Memorandum of Economic and Financial Policies}

\section{A. Recent Economic Developments and Outlook}

1. Ireland's economic recovery slowed in the first half of 2012 and the outlook is for a modest pick up in growth in 2013. Real GDP growth fell to $1 / 2$ percent $y / y$ in the first half of 2012 as net exports weakened. Net exports remained the sole driver of economic growth, with domestic demand and employment continuing to fall, and unemployment has remained elevated at 14.8 percent. At the same time, lower net income outflows boosted GNP growth to $2 \frac{1}{4} 4$ percent $y / y$ and the current account surplus to 2.7 percent of GDP, although a reversal of some of these gains may be seen in the second half. HICP inflation rose to 2.0 percent y/y during the first three quarters of 2012 on the back of surging energy costs and administered price increases. Growth strengthening to over 1 percent is projected for 2013, but this pick up may be impeded by weaker growth expected in trading partners. In addition, further domestic demand contraction is expected as financial sector weaknesses, continuing uncertainties, together with the heavy debt burdens of households and SMEs, hinder lending, drive saving, and curb investment.

\section{Ireland has started to regain access to market funding in recent months, aided} by policy developments at the European level. Irish sovereign bond yields fell dramatically over the summer, benefitting from continued strong program implementation and the June 29 summit statement, providing an opportunity to re-enter the international bond market earlier and on more favourable terms than expected. Irish bond markets were boosted further by the ECB's OMT announcement in early September, with 8-year bond yields down to below 5 percent. We recognise that continued strong policy implementation is essential. In addition, with expectations of further European support priced in by the market, timely delivery on commitments to examine the situation of the Irish financial sector with the view of improving the sustainability of Ireland's adjustment program is necessary to maintain the positive momentum and facilitate our efforts to exit from reliance on official financing.

\section{B. Fiscal Policies}

\section{We will meet the fiscal targets for 2012 and extend our track record of sound} budgetary management. The end-September targets on the exchequer primary balance and central government net debt were met with respective margins of 0.8 and 1.5 percentage points of GDP. Tax revenues are ahead of profile despite more challenging macroeconomic conditions, reflecting our prudent costing of measures and robust revenue collection efforts. Strong revenues, along with spending restraint in most areas, will compensate for overspending in health and social welfare, the latter on account of higher-than-expected unemployment. Overall, we are on track to deliver a general government deficit within the 8.6 percent of GDP target for 2012 . 
4. We are alert to the overrun in current health spending, and are taking the measures necessary to unwind it. We are committed to achieving health outcomes in an efficient manner and will contain health expenditure next year to within the $€ 13.6$ billion departmental ceiling for 2013 set in the Comprehensive Expenditure Report 2012-14, including by fully correcting the overrun from 2012. To this end, we have recently negotiated a significant multi-year reduction in the price of pharmaceuticals, and are seeking further durable savings, including through consideration of a range of structural reforms to:

- Further reduce drug costs, including by lowering the price of generic drugs and increasing the share of generics in prescriptions, dispensing and usage;

- Enhance hospital efficiency, by implementing major work practice and rostering reforms, reducing the average length of hospital stays, increasing the share of day treatments, and minimising unnecessary return visits for out-patients;

- Improve the charging regime for private patients in public hospitals and increase collection of charges, to fully account for costs; and

- Better target spending, particularly within the primary care re-imbursement scheme.

5. The recently-updated Medium-Term Fiscal Statement (MTFS) demonstrates our continued commitment to put the public finances on a sound footing. As set out in the table below, we will be implementing consolidation measures of at least $€ 8.6$ billion over the next three years to bring the general government deficit below 3 percent of GDP by 2015, in line with the Stability and Growth Pact targets. We consider that this adjustment path strikes the right balance between debt sustainability and protecting growth and jobs.

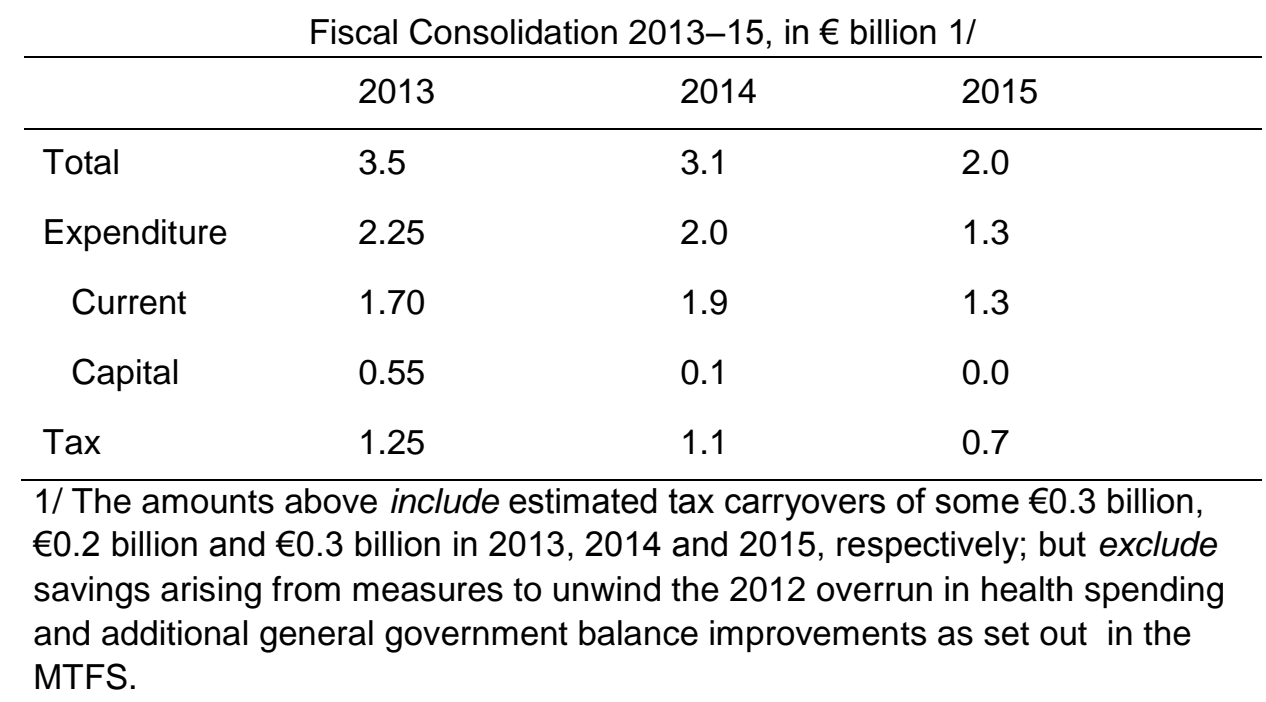

6. We will submit Budget 2013 to the Oireachtas on December 5 to deliver these targets for 2013 (prior action). In order to safely achieve the general government deficit below the program ceiling of 7.5 percent of GDP, the package will include: (i) primary 
current expenditure adjustments of $€ 1.7$ billion (excluding measures taken to unwind the 2012 health spending over-run); (ii) reductions in capital spending of $€ 0.55$ billion, consistent with the Infrastructure and Capital Investment Plan 2012-16; (iii) new tax measures of $€ 1$ billion; and (iv) additional general government balance improvements, including in respect of the local government sub-sector, as set out in the MTFS.

\section{Our budget will select a balance of expenditure and tax measures to achieve the consolidation in a durable, equitable and growth-friendly manner.}

\section{Current expenditure measures:}

- Accelerated reduction in the public sector wage bill: We will build on the recent overtime and sick pay reforms by targeting unjustified pay allowances for elimination, or medium-term restructuring. We are considering all options to improve the sustainability of the public sector wage bill, in order to achieve the envisaged current expenditure savings while protecting the delivery of public services.

- More targeted social supports and subsidies: We are reviewing a range of social transfers, including universal benefits, with a view to identifying savings while protecting the most vulnerable and minimising work disincentives. This review will take into account the Comprehensive Review of Expenditure and the projected increase in age-related spending, as highlighted in the recent actuarial review of the Social Insurance Fund. Student contributions to the cost of tertiary education are being raised, and a more stringent means-test for maintenance grants for undergraduates is being introduced.

\section{Tax measures:}

- Introduction of property tax: We are rolling out a recurrent tax on the value of private residences from July 1, 2013 to replace the household charge. The tax will be collected centrally by the Revenue Commissioners and will constitute an important and stable source of revenue.

- Tax base broadening: We are broadening the base for personal income taxes and pay related social insurance (PRSI) including by better targeting reliefs and tightening allowances.

- Raising indirect tax revenues: Following an intensive public consultation on environment-related taxation, we have decided to recalibrate the $\mathrm{CO}_{2}$ band structure for vehicle registration and motor taxes. Options in relation to other indirect taxes, including excises, are also being considered. 
8. At the time of Budget 2013, we will specify as far as possible the tax and spending measures for the 2014-15 consolidation. We are confident that the permanent consolidation measures outlined above will yield significant carry-over savings for 2014-15, reducing the residual consolidation to be identified. An early specification of this remaining consolidation will reduce uncertainties faced by households and businesses and thereby help support the revival of domestic demand.

9. Having completed the core institutional fiscal reforms, we are looking to advance fiscal transparency. The Fiscal Responsibility Bill will be signed into law on November 27, enshrining the independence of the Irish Fiscal Advisory Council, and establishing the fiscal rules for deficits and debt. We have published the legislation (amendment to the Ministers and Secretaries Act) to provide a statutory basis for the already operational multi-annual expenditure ceilings. We published an enhanced Exchequer statement at end-September 2012 and are seeking to further strengthen the reporting of general government accounts and fiscal risks (given the state's large asset and liability positions).

10. We will continue to press forward with major public service reforms, which will further support budgetary sustainability into the medium term. As the recent Progress Update on the November 2011 Public Service Reform Plan shows, major projects are being rolled out in the area of shared services, public procurement and the identification and evaluation of opportunities for external service delivery. In this overall context, the Public Service Agreement is operating as a key enabler of reform and productivity, helping to eliminate waste and to manage the ongoing reduction in public sector headcount while minimising the impact on service levels. We will step up our engagement with staff interests to ensure that all aspects of the Agreement are leveraged to enhance public sector efficiency to the fullest extent possible.

\section{Financial Sector Policies}

11. The key objective of our financial sector policy is to improve the health of the banking sector and thereby revive sound lending in support of the economic recovery. While considerable progress has been made in recapitalising and deleveraging the PCAR banks, they continue to face significant asset quality, profitability, and liquidity challenges. Accordingly, we will gear our efforts towards ensuring the banks are: (i) managing their loan portfolios to arrest the deterioration of asset quality, (ii) improving their profitability through reductions in funding and operational costs, and (iii) advancing the restructuring of the banks. The effectiveness of these efforts would be greatly facilitated by the timely delivery of further European support along the lines indicated in the euro area summit statement of June 29, 2012.

12. We are driving forward the effective implementation of the residential mortgage arrears resolution process. We have made the resolution of mortgage arrears a top priority for banks, and are supervising their efforts to (i) set up and grow efficient loan collection 
operations; (ii) engage effectively with households in arrears; and, (iii) address unsustainable debt in a durable manner. Nonetheless, the rise in long dated arrears has continued. Banks have implemented pilots of mortgage resolution options and in some cases gone live with their strategies and we are taking the following steps to facilitate the stronger progress on implementation that is needed:

- We will closely supervise banks' progress in achieving a durable reduction in mortgage arrears. The MARS process will seek to ensure that: (i) borrowers in arrears are contacted in a timely fashion: (ii) subject to tight eligibility criteria, distressed debtors are offered sustainable loan modification options; and, (iii) other durable solutions are adopted where appropriate, including repossession proceedings, voluntary surrender, or mortgage to rent. We will monitor each bank's performance relative to already-defined key performance indicators for progress in resolving problem loans, and also against bank specific targets for reviewing new and existing individual arrears cases.

- We will continue the implementation of the framework to monitor the effectiveness of the loan modification process. We will publish banks' reported data on loan modifications, including re-defaults of modified loans, to permit analysis of the effectiveness of alternative resolution approaches in improving debt service performance.

- We will ensure appropriately prudent provisioning treatment of loan modifications. We will continue to engage with banks and review the proposed provisioning treatment for all advanced loan modification products being introduced as part of their mortgage arrears resolution strategies. In addition, we will, in consultation with staff of the EC, ECB, and the IMF, update where necessary the 2011 Impairment Provisioning and Disclosure guidelines setting out the appropriate assumptions for all categories of advanced loan modifications.

- To encourage and facilitate more active engagement with borrowers by banks, we will review the Code of Conduct for Mortgage Arrears. In particular, we will conduct the review to commence in early 2013 to take account of developments in the arrears environment such as the forthcoming Personal Insolvency legislation and the longer term loan modifications that will be rolled out by the banks.

- Having secured adequate protections for debtors' principal private residence through the enactment of the Personal Insolvency Bill, we will by end March 2013 introduce legislation remedying the issues identified by case law in the 2009 Land and Conveyancing Law Reform Act, so as to remove unintended constraints on banks to realise the value of loan collateral under certain circumstances.

- We will undertake a review of progress in addressing mortgage arrears by end-June 2013 (proposed structural benchmark). 
13. Establishing the new personal insolvency framework will support these efforts and help reduce household debt distress while maintaining debt service discipline. The Personal Insolvency Bill has passed the committee stage in the Dáil and is expected to complete all Oireachtas stages by year-end. We will introduce further amendments ahead of its enactment including the licensing and regulation of personal insolvency practitioners. We are establishing the infrastructure to make the new insolvency framework operational by end January 2013 or very shortly thereafter. A newly appointed Director Designate of the Insolvency Service has been equipped with the resources to (i) develop the necessary IT infrastructure as early as possible in 2013, (ii) hire and train staff (iii) to publish, in particular in the context of the Debt Relief Notice process, and drawing on relevant research, guidelines for reasonable allowable household expenditures for debtors and (iv) conduct an information campaign for all likely to be concerned by the new insolvency processes. We have also completed the establishment of the Mortgage Advisory Service accessible through the internet where debtors can avail of a consultation with an independent financial advisor upon authorisation by their lender when offered advanced mortgage modification/long term forbearance under MARS.

14. Resolving the balance sheet challenges of SMEs is critical to restoring their capacity to invest and create jobs. We have recently launched the Temporary Partial Credit Guarantee scheme to facilitate lending to eligible SMEs. However, Irish SMEs with high indebtedness, often related to real estate investments, are often hampered in their ability to finance working capital and productive investments. Accordingly:

- The CBI will monitor banks' implementation of arrears resolution strategies for SMEs. The findings of the CBI review in this area were communicated to PCAR banks in August. Banks are strengthening their strategies and deploying adequate operational capacity to move away from short-term forbearance to more durable restructuring solutions.

- We will improve the efficiency of the corporate insolvency framework for SMEs, drawing on the recommendations in the recent report by the Company Law Review Group. In particular, by end-year we will prepare amendments to designate the Circuit Courts as competent for the examinership of companies within the EU small company thresholds (e.g., balance sheet below $€ 4.4$ million). Based on experience with the operation of the Insolvency Service in the personal insolvency reform, we will consider the appropriateness of further enhancements to the legal framework to reduce costs and achieve efficiency gains, including the potential for an administrative body to facilitate SME restructuring.

15. We are redoubling our efforts to return PCAR banks to profitability, including by finalising a roadmap for the orderly withdrawal of the ELG Scheme. We will continue to encourage further reductions of funding costs and urge continued operating cost savings in order to reduce their pre-provision operating losses. The strategy for weaning the 
banking system off the ELG Scheme while preserving financial stability, currently being developed by the inter-agency working group led by the Department of Finance, will be finalised by end-2012.

16. We continue to advance bank restructuring. PTSB has undertaken its initial internal reorganisation, including separation into three discrete business units with separate management accounts. We will monitor PTSB's performance against the benchmarks proposed for the three business units. AIB and PTSB have submitted restructuring plans to the competent EC authority, with a view to restoring core profitability.

17. We are finalising the framework to restore the viability and solvency of the credit union sector. Drawing on the recommendations in the Report of the Commission on Credit Unions issued in March, the Credit Union Bill 2012 was published on September 28. The Bill strengthens the regulatory framework of credit unions with a focus on four areas: prudential regulation, governance, restructuring and stabilisation. We are refining the Bill, including to clarify, that, to the extent any public resources provided for the purpose of restructuring of credit unions are not reimbursed by the restructured institution, they will be recouped in full by means of a levy on the credit union industry. The restructuring process will be led by a Restructuring Board (ReBo), which will be mandated to underpin the sustainability of the credit union sector in a planned and time-bound manner. The ReBo will work with credit unions to bring forward restructuring proposals, which will be subject to CBI regulatory approval. To facilitate this restructuring process, we will transfer $€ 250$ million to a Credit Union Fund by end 2012, and we request an adjustor to the performance criterion on the exchequer primary balance and the indicative target on the stock of central government net debt.

18. We will provide by end 2012 a report reviewing developments relative to PCAR 2011. The review will analyse indicators of banks' financial performance versus the PCAR base and stress case assumptions, and will assess the impact of the evolution of economic drivers. These indicators will include credit quality, loan loss provisions, losses from deleveraging, and pre-provision net revenue. The analysis will take into account significant deviations from PCAR 2011 assumptions, such as in liability management exercises. The report will also provide details of the evolution of risk weighted assets.

\section{We are continuing to strengthen financial supervision and regulation. Key} deliverables will be as follows:

- Supervision and Enforcement Legislation: Efforts to finalise the Central Bank (Supervision and Enforcement) Bill are on-going and the committee stage amendments are expected to be finalised shortly. We recognise the criticality of this legislation, especially with regard to strengthening the CBI's investigation, direction and enforcement powers, and are determined to move the Bill forward expeditiously. 
- Banking supervision and securities regulation: The CBI has begun an internal selfassessment of Ireland's observance of the recently revised Basel Core Principles (BCP)for Effective Banking Supervision. We will request an external BCP assessment by end March (proposed structural benchmark), with the aim to be completed by end-December 2013. We will also complete an International Organisation of Securities Commissions, (IOSCO) Objectives and Principles of Securities Regulation self-assessment, and will request an external assessment with the aim to be completed by end-December 2013.

- Resolution fund levy: In September, we issued regulations for a levy on credit institutions designed to accumulate funding over the medium to long term to build a fund for resolution actions of $€ 100 \mathrm{~m}$. We intend to recoup the public resources provided to the Resolution Fund mainly for the resolution of credit unions. Upon publication of the EU directive establishing a framework for the recovery and resolution of credit institutions and investment firms, we will review this regulation.

- Risk weighted assets: The CBI is well advanced in enhancing its approach to Credit Risk, risk weighted asset (RWA) supervision including conducting annual model performance reviews, assessing RWA calculation and reviewing banks' approaches to RWA forecasting and stress testing in advance of PCAR 2013. The next steps will include completing the reviews and issuing mitigating actions for the banks concerned by end 2012 .

20. We will put in place an effective credit register to facilitate sound lending decisions and to aid financial supervision. Issues of data protection have delayed finalisation of the Credit Reporting Bill 2012 that was published last September. Following the publication of the Bill at end-September 2012, a consultation process has commenced to consider potential Committee Stage amendments. Following the completion of the parliamentary process, the Central Bank, as the owner, will undertake a procurement exercise, with the goal of having the Register operational by end 2013.

\section{Structural Reforms}

21. Enhancing growth and job creation remains our top priority. Commencing in 2013, we are supplementing our exchequer capital expenditure programme by $€ 1.4$ billion through public-private partnerships with the European Investment Bank, the National Pension Reserve Fund, and private investors. Projects have been identified in education, transport, health care, and justice. We are also proceeding with the disposal of state assets in the energy generation and forestry sectors in 2013 as planned, while the sale of a minority stake in Aer Lingus hinges on market conditions and antitrust concerns. We will use at least half of the proceeds from these asset disposals to reduce public debt in due course, with the details on timing and implementation to be agreed. Once realised, the remaining proceeds will be reinvested in job-rich projects of a commercial nature, consistent with our fiscal targets. 
22. We are continuing to implement the Action Plan for Jobs, which aims to support employment creation through wide-ranging set of measures. We have implemented almost 90 percent of the planned measures by end September, including: establishing new Technology Centres in Cloud Computing, Learning Technologies and Financial Services; launching of the Microfinance Fund that will provide small loans to businesses with up to 10 employees; and initiating an intra-agency partnership Smart Futures for promoting careers in science. To bring down the cost of doing business, we have reduced stamp duty and have introduced capital gains tax incentives for certain types of properties. We will continue to identify and implement measures to improve the business climate in 2013 and beyond, with a focus on promoting access to finance and investment by SMEs, supporting indigenous start ups and assisting indigenous business to grow, and developing and deepening the impact of foreign direct investment.

\section{We are stepping up our reforms of activation, training, and social welfare} payments to help reduce unemployment over time:

- Pathways to Work. We have launched the new one-stop shop unemployment support service-Intreo - in four locations, and expect to have ten offices operational by end-2012. By combining the previously separate services of the Department of Social Protection, FAS, and the Community Welfare Service, Intreo will provide a more coherent and tailored package of employment services. Under the new system, engagement with job seekers will take place on a contractual basis with welfare payments contingent on participation in activation programs and job search efforts, where a lack of engagement would result in sanctions. We will triple the number of 'live' offices to 30 by the end of 2013, with a further 30 coming on stream before the end of 2014. This roll out will accelerate profiling of job seekers and further increase engagement at both the group and the individual level.

- Engagement with long term unemployed. We are taking steps to increase engagement with long term unemployed people through their inclusion in the Intreo activation process through greater use of the Local Employment Services Network, more targeted use of Community Employment and other work placement schemes, appropriate training schemes and through increased promotion of employer incentives encouraging the recruitment of long term unemployed people. It is anticipated that these steps, together with external contracting (see next bullet point) will enable the delivery of the targets with respect to long term unemployment set out in the Pathways to Work policy document.

- Involving the private sector in employment services provision, especially for the long-term unemployed. We have established a cross-departmental working group to oversee the process of engaging private employment services firms, which will expand resources to service the needs of job seekers, helping address the current shortfall in qualified case workers. By end-February 2013 we will prepare draft remuneration contracts for the private firms that are in line with international best 
practice with support from external experts. We plan to issue a tender for the provision of services by end March 2013, and these new services are expected to be operational by end-2013.

- Reforming the further education system, including for the unemployed. In order to strengthen training provision, we have recently published legislation to establish 16 Education and Training Boards, replacing the existing 33 Vocational Education Committees. The action plan for establishing SOLAS - an institution to coordinate and fund training and further education programs - will be completed by end-November, and by the end-December we will publish legislation to launch SOLAS. We have completed a financial review of the Community Employment programme, and by end-January 2013 we will prepare a comprehensive review of activation programs, which will guide us in further reforming the activation and training services provided to the unemployed.

- Housing assistance. We intend to replace the current rent supplement for individuals with a long-term housing need with a new Housing Assistance Payment (HAP). Operated by the relevant housing authority, HAP will allow rent supplement to address its original objective as a short-term income support measure and will provide for the creation of an integrated social housing market. One of the benefits of HAP will be that it will be based on a differential rent, therefore enabling employment take-up by tenants who may previously have been caught in a poverty trap if they entered the workforce. Before HAP can be implemented, it will be necessary to introduce a system of non-discretionary deduction of rent. It is intended that this issue will be addressed via legislative amendments in the Social Welfare Budget Bill, 2012 (by end December 2012) to amend the Household Budgeting Scheme and the Social Welfare \& Pensions Bill, 2013 in Spring 2013 (by end June 2013) to facilitate non-discretionary deduction on a wider level. It will also be necessary to enact the Housing (Miscellaneous Provisions) Bill, 2012 (summer 2013). It is the intention that HAP will be piloted in the second half of 2013 and made fully operational in 2014 with general roll out and commencement of transfers from early January 2014.

\section{E. Programme Financing and Monitoring}

\section{Our financing strategy aims to ensure the program is adequately financed and to} help develop the basis for moving towards relying on market access. Following our return to Treasury bond and bill issuances in July, we have instituted monthly Treasury bill auctions, with yields now below 1 percent, and we have also raised $€ 1$ billion in long-term funding with an initial issue of amortising bonds targeted at domestic pension funds. Building on this progress, we will seek to further broaden our investor base and increasingly move to regular bond issuances, which will account for a rising share of our financing. We will also continue to tap other sources such as amortising bonds when market conditions are favourable. In view of the external risks to our financing, we will continue to maintain a 
prudent cash buffer and aim to end the programme with a buffer covering around one year of financing needs to support market confidence.

25. Implementation of the policies under the programme will continue to be monitored through quarterly and continuous performance criteria, indicative targets, structural benchmarks, and quarterly programme reviews, as envisaged in our Letters of Intent since the inception of the arrangement on 3 December 2010 along with this letter. The programme also continues to be in compliance with requirements under the Memorandum of Understanding on Specific Policy Conditionality. The attached Technical Memorandum of Understanding (TMU) defines the quantitative performance criteria and indicative targets under the programme. The Government's targets for the exchequer primary balance are monitored through quarterly performance criteria and net central government debt is an indicative target (Table 2). As is standard in EU/IMF arrangements, there is a continuous performance criterion on the non-accumulation of external payment arrears. Progress on implementing structural reforms is monitored through structural benchmarks (Tables 1 and 3).

26. We authorise the IMF and the European Commission to publish the Letter of Intent and its attachments, and the related staff report. 
Table 1. Programme Monitoring

\begin{tabular}{|c|c|c|}
\hline Measure & Date & Status \\
\hline \multicolumn{3}{|l|}{ Quantitative Performance Criteria } \\
\hline Cumulative exchequer primary balance & End-September 2012 & Observed \\
\hline \multicolumn{3}{|l|}{ Indicative Target } \\
\hline Ceiling on the stock of central government net debt & End-September 2012 & Observed \\
\hline $\begin{array}{l}\text { Continuous Performance Criteria } \\
\text { Ceiling on the accumulation of new external payments arrears on } \\
\text { external debt contracted or guaranteed by the central government }\end{array}$ & Continuous & Observed \\
\hline \multicolumn{3}{|l|}{ Structural Benchmarks } \\
\hline $\begin{array}{l}\text { Define the criteria to run stringent stress tests scenarios. } \\
\text { Agree on terms of reference for the due diligence of bank assets by } \\
\text { internationally recognised consulting firms. }\end{array}$ & $\begin{array}{l}\text { End-December } 2010 \\
\text { End-December } 2010\end{array}$ & $\begin{array}{l}\text { Observed } \\
\text { Observed }\end{array}$ \\
\hline $\begin{array}{l}\text { The Central Bank will direct the recapitalisation of the principal banks } \\
\text { (AIB, Bol and EBS) to achieve a capital ratio of } 12 \text { percent core tier } 1 \text {. }\end{array}$ & End-February 2011 & $\underset{1 /}{\text { Not observed }}$ \\
\hline $\begin{array}{l}\text { Submit to Dáil Éireann the draft legislation on a special resolution } \\
\text { regime. }\end{array}$ & End-February 2011 & Observed $^{2 /}$ \\
\hline $\begin{array}{l}\text { The Central Bank to complete the assessment of the banks' } \\
\text { restructuring plans. }\end{array}$ & End-March 2011 & Observed \\
\hline Complete the diagnostic evaluation of banks' assets. & End-March 2011 & Observed \\
\hline Complete stress tests (PCAR 2011). & End-March 2011 & Observed \\
\hline Complete a full assessment of credit unions' loan portfolios & End-April 2011 & Observed \\
\hline Finalise plans for the recapitalisation of Irish Life and Permanent. & End-May 2011 & Observed \\
\hline Establish a Fiscal Advisory Council. & End-June 2011 & Observed \\
\hline $\begin{array}{l}\text { Complete the recapitalisation of Allied Irish Banks, Bank of Ireland, } \\
\text { Irish Life and Permanent and EBS Building Society. }\end{array}$ & End-July 2011 & Observed \\
\hline Submit the Supervision and Enforcement Bill to Oireachtas. & End-July 2011 & Observed \\
\hline $\begin{array}{l}\text { Complete the legal merger procedures of Allied Irish Bank and EBS } \\
\text { Building Society. }\end{array}$ & End-September 2011 & Observed \\
\hline $\begin{array}{l}\text { Publish a memorandum of understanding governing the relationship } \\
\text { of the Department of Finance and the Central Bank in relation to } \\
\text { banking sector oversight. }\end{array}$ & End-October 2011 & Observed $^{3 /}$ \\
\hline The merger of Irish Nationwide Building Society and Anglo-Irish bank. & End-December 2011 & Observed \\
\hline $\begin{array}{l}\text { Central Bank to issue guidance to banks for the recognition of } \\
\text { accounting losses incurred in their loan book. }\end{array}$ & End-December 2011 & Observed \\
\hline
\end{tabular}


Table 1. Programme Monitoring (concluded)

\begin{tabular}{lll}
\hline Measure & Date & Status \\
\hline $\begin{array}{l}\text { Finalise a strategy to guide the development of broader legal reforms } \\
\text { around personal insolvency, including significant amendments to the }\end{array}$ & End-December 2011 & Observed \\
$\begin{array}{l}\text { Bankruptcy Act } 1998 \text { and the creation of a new structured non- } \\
\text { judicial debt settlement and enforcement system. }\end{array}$ & \\
$\begin{array}{l}\text { Introduce a medium-term expenditure framework with binding multi- } \\
\text { annual expenditure ceilings with broad coverage and consistent with } \\
\text { the fiscal consolidation targets. }\end{array}$ & $\begin{array}{l}2012 \text { Budget day in } \\
\text { early December 2011 }\end{array}$ & Observed \\
$\begin{array}{l}\text { Updated restructuring plan for the PTSB detailing the actions needed } \\
\text { to ensure viability of its core businesses. }\end{array}$ & End-June 2012 & Observed \\
$\begin{array}{l}\text { Submit to parliament, as part of the Fiscal Responsibility Bill, a legal } \\
\text { framework for the Fiscal Advisory Council ensuring its independence. }\end{array}$ & End-September 2012 & Observed \\
$\begin{array}{l}\text { Publish legislation to strengthen the regulatory framework for credit } \\
\text { unions, including making legislative provision for effective }\end{array}$ & End-September 2012 & Observed \\
governance standards and prudential requirements & & \\
& & \\
$\begin{array}{l}\text { Approve regulations to establish a charge levied across credit } \\
\text { institutions to recoup over time the costs of resolving vulnerable } \\
\text { institutions }\end{array}$ & End-September 2012 & Observed \\
\hline
\end{tabular}

$1 /$ Central Bank directions were issued within the required timeframe. However, completion of the capital injections required was postponed by the Minister for Finance until after the General Election. These directions are now superseded by the Central Bank's PCAR directions of 31 March 2011.

2/ In practice this was submitted to the Seanad as discussed in paragraph 21 of the MEFP, as the Dáil was dissolved owing to the elections.

3/ Effective end-October 2011 and posted on November 8, 2011. 
Table 2. Ireland: Quantitative Performance Criteria and Indicative Targets

Under the Economic Programme for 2011-13

\begin{tabular}{|c|c|c|c|c|c|c|c|c|c|c|c|c|}
\hline & \multicolumn{2}{|c|}{ 31-Dec-11 } & \multicolumn{2}{|c|}{ 31-Mar-12 } & \multicolumn{2}{|c|}{ 30-Jun-12 } & \multicolumn{2}{|c|}{ 30-Sep-12 } & \multirow{2}{*}{$\frac{\text { 31-Dec-12 }}{\text { Target }}$} & \multicolumn{2}{|c|}{ 31-Mar-13 30-Jun 13} & \multirow{2}{*}{$\frac{30-\text { Sep-13 }}{\text { Target }}$} \\
\hline & Target $1 /$ & Outcome & Target 1/ & Outcome & Target $1 /$ & Outcome & Target1/ & Outcome & & Target & Target & \\
\hline & \multicolumn{12}{|c|}{ (In billions of Euros) } \\
\hline & \multicolumn{2}{|c|}{$\begin{array}{l}\text { Performance } \\
\text { Criterion }\end{array}$} & \multicolumn{2}{|c|}{$\begin{array}{c}\text { Performance } \\
\text { Criterion }\end{array}$} & \multicolumn{2}{|c|}{$\begin{array}{c}\text { Performance } \\
\text { Criterion }\end{array}$} & \multicolumn{2}{|c|}{$\begin{array}{c}\text { Performance } \\
\text { Criterion }\end{array}$} & $\begin{array}{c}\text { Performance } \\
\text { Criterion }\end{array}$ & $\begin{array}{c}\text { Performance } \\
\text { Criterion }\end{array}$ & $\begin{array}{l}\text { Indicative } \\
\text { Target 4/ }\end{array}$ & $\begin{array}{l}\text { Indicative } \\
\text { Target 4/ }\end{array}$ \\
\hline \multirow{3}{*}{$\begin{array}{l}\text { 1. Cumulative } \\
\text { exchequer primary } \\
\text { balance } 2 / \\
\text { 2. Ceiling on the } \\
\text { accumulation of new } \\
\text { external payments } \\
\text { arrears on external } \\
\text { debt contracted or } \\
\text { guaranteed by the } \\
\text { central government } 3 /\end{array}$} & -22.3 & -21.0 & -6.9 & -5.7 & -9.6 & -8.7 & -11.4 & -10.1 & -11.2 & -3.7 & -4.3 & -4.9 \\
\hline & 0 & 0 & 0 & 0 & 0 & 0 & 0 & 0 & 0 & 0 & 0 & 0 \\
\hline & \multicolumn{2}{|c|}{ Indicative Target } & \multicolumn{2}{|c|}{ Indicative Target } & \multicolumn{2}{|c|}{ Indicative Target } & \multicolumn{2}{|c|}{ Indicative Target } & $\begin{array}{c}\text { Indicative } \\
\text { Target }\end{array}$ & $\begin{array}{c}\text { Indicative } \\
\text { Target }\end{array}$ & $\begin{array}{l}\text { Indicative } \\
\text { Target }\end{array}$ & $\begin{array}{c}\text { Indicative } \\
\text { Target }\end{array}$ \\
\hline $\begin{array}{l}\text { 3. Ceiling on the stock } \\
\text { of central government } \\
\text { net debt } 1 /\end{array}$ & 117.2 & 115.7 & 125.0 & 123.0 & 130.1 & 128.2 & 132.5 & 130.0 & 135.5 & 143.1 & 149.2 & 150.4 \\
\hline
\end{tabular}

\section{$1 /$ Adjusted.}

2/ Measured by the exchequer balance excluding interest payments. Cumulative from the start of the relevant calendar year.

3/ Applies on a continuous basis.

4/ Exchequer primary balance targets after 31-December 2012 exclude payments in respect of the IBRC Promissory Note that have thus far - for program purposes - been considered part of exchequer non-voted capital spending. 
Table 3. Ireland: Upcoming Prior Action and Structural Benchmarks under the Programme

\begin{tabular}{|c|c|c|}
\hline Measure & Date & Status \\
\hline \multicolumn{3}{|l|}{ Financial sector policies } \\
\hline $\begin{array}{l}\text { Request an external BCP assessment in support of } \\
\text { efforts to strengthen financial supervision and regulation } \\
\text { (MEFP }\{19 \text { ). }\end{array}$ & End-March 2013 & $\begin{array}{l}\text { Proposed } \\
\text { structural } \\
\text { benchmark }\end{array}$ \\
\hline $\begin{array}{l}\text { Undertake a review of progress in addressing mortgage } \\
\text { arrears (MEFP } \uparrow 12 \text { ). }\end{array}$ & End-June 2013 & $\begin{array}{l}\text { Proposed } \\
\text { structural } \\
\text { benchmark }\end{array}$ \\
\hline \multicolumn{3}{|l|}{ Fiscal policies } \\
\hline Submit Budget 2013 to the Oireachtas (MEFP $₫ 6$ ). & 5 December 2012 & Prior action \\
\hline
\end{tabular}




\title{
Attachment III. Technical Memorandum of Understanding (TMU)
}

\author{
November 29, 2012
}

1. This Technical Memorandum of Understanding (TMU) sets out the understandings regarding the definitions of the indicators subject to performance criteria and indicative targets under the arrangement supported by the Extended Fund Facility (EFF). These performance criteria and indicative targets are reported in Table 2 attached to the Memorandum of Economic and Financial Policies (MEFP). This TMU also describes the methods to be used in assessing the programme performance and the information requirements to ensure adequate monitoring of the targets.

2. For programme purposes, all foreign currency-related assets, liabilities, and flows will be evaluated at "programme exchange rates", with the exception of the items affecting the government fiscal balances, which will be measured at current exchange rates. The programme exchange rates are those that prevailed on December 30, 2011 as shown on the IMF's website (http://www.imf.org/external/np/fin/data/rms_five.aspx, accessed 19 January 2012), in particular, $€ 1=1.2939$ U.S. dollar and $€ 1=0.842786$ SDR.

\section{Quantitative Performance Criteria And Indicative Targets}

\section{Floor on the Exchequer Primary Balance}

3. The Exchequer balance is the traditional domestic budgetary aggregate which measures the net surplus or net deficit position of the Exchequer Account. The Exchequer Account is the single bank account of the Central Fund and is held at the Central Bank of Ireland. The annual audited accounts of the Exchequer Account produced by the Department of Finance are known as the Finance Accounts. An unaudited summary known as the Exchequer Statement is produced at the end of each month. Under the Irish Constitution, all Government receipts are paid in to the Central Fund and all Government expenditure is funded from it, unless provided otherwise by law. ${ }^{1}$ The Exchequer balance is the difference between total receipts into, and total expenditure out of, the Exchequer Account. It measures the sum of the current and capital balances. The current balance is defined as current receipts (tax and non-tax revenue) minus current expenditure (voted expenditure and non-voted expenditure charged directly on the Central Fund, including the Sinking Fund). The capital balance is defined as capital receipts (Sinking Fund and other capital receipts) minus capital expenditure (voted and non-voted expenditure). The Sinking Fund provision is a transfer

\footnotetext{
${ }^{1}$ Receipts of the Central Fund comprise Exchequer tax revenues, non-tax revenues, receipts from the European Union and other capital receipts. Charges on the Central Fund include the expenditure of Government departments and offices, payments related to the servicing of the national debt, payments to the European Union Budget, the salaries, pensions and allowances of the President, judiciary, and Comptroller \& Auditor General and the running costs of the Houses of the Oireachtas (Parliament). Extra-budgetary funds (including the National Pensions Reserve Fund), the Social Insurance Fund, semi-state bodies and local governments are not part of the Exchequer system.
} 
from the current account to the capital account to reduce national debt and has no effect on the overall Exchequer balance.

4. The performance criteria are set on the Exchequer primary balance which is the Exchequer balance excluding net debt interest payments in the service of the National Debt. From January 2013 all payments related to the IBRC promissory notes are excluded from the Exchequer primary balance measure used for programme monitoring purposes. ${ }^{2}$

5. For the purposes of the programme, the floor on the Exchequer primary balance (quantitative performance criterion) will be adjusted

(i) downward by payments for bank restructuring carried out under the programme's banking sector support and restructuring strategy. Such payments may include, inter alia, loans to banks, investments in their equity (requited recapitalisation), unrequited recapitalisation, and purchases of troubled assets, which are carried out in line with programme objectives,

(ii) upward by the amount of proceeds from sales of bank equity held by the government or NPRF that are treated as Exchequer receipts,

(iii) upward by the amount of receipts from disposals of state assets specified in the paragraph 21 of the MEFP dated 29 November 2012,

(iv) downward by the amount of these receipts spent on growth-enhancing projects not included in Budget 2013, up to no more than half of these receipts,

(v) downward for Exchequer contributions to the Resolution Fund for the resolution of credit institutions, and upward for any Exchequer recoupment from the Resolution Fund, of such outlays.

(vi) downward for Exchequer contributions to the Credit Union Fund for the restructuring of credit unions up to $€ 250$ million cumulatively, and upward for any Exchequer recoupment, from the Credit Union Fund, of such outlays.

Any other financial operation by Government to support banks or other credit institutions including credit unions, including the issuance of guarantees or provision of liquidity, will be reported to EC, IMF, and ECB staffs.

6. The floor on the Exchequer primary balance (quantitative performance criterion) in each year will be measured cumulatively from the start of that calendar year.

\footnotetext{
${ }^{2}$ Net debt interest payments are as per the end-month Exchequer Statements.
} 


\begin{tabular}{ll}
\hline Cumulative Exchequer primary balance & (In billions of Euros) \\
\hline From January 1, 2012: & -11.2 \\
$\quad$ End-December 2012 (performance criterion) & \\
& \\
From January 1, 2013 & -3.7 \\
End-March 2013 (performance criterion) & -4.3 \\
End-June 2013 (indicative target) & -4.9 \\
End-September 2013 (indicative target) & \\
\hline
\end{tabular}

7. The performance criterion on the Exchequer primary balance (floor) will be adjusted upward (downward) for the full amount of any over-performance (under-performance) in Exchequer tax revenues, pay-related social insurance contributions (PRSI) and national training fund contributions against the current projection which is listed below: ${ }^{3}$

\begin{tabular}{ll}
$\begin{array}{l}\text { VII. Cumulative Exchequer tax revenue \& other receipts (as } \\
\text { outlined in 7. above) }\end{array}$ & VIII. (In billions of Euros) \\
\hline $\begin{array}{l}\text { From January 1, 2012: } \\
\text { End-December 2012 (projection) }\end{array}$ & 44.1 \\
& \\
From January 1, 2013 & 10.2 \\
End-March 2013 (projection) & 20.9 \\
End-June 2013 (projection) & 32.2 \\
End-September 2013 (projection) & \\
\hline
\end{tabular}

8. Any policy changes, including in administration and enforcement of taxes, which impact the revenue projection set out in paragraph 7 will lead to a reassessment of the adjustor in the context of program reviews.

\section{Ceiling on the Stock of Central Government Net Debt}

9. The stock of net central government debt, for the purposes of the programme, is defined as the National Debt less liquid assets of the National Pensions Reserve Fund (NPRF). The National Debt is defined as the total outstanding amount of principal borrowed by central government and not repaid as of the test date, less liquid assets available for redemption of those liabilities at the same date. These liquid assets comprise the Exchequer cash balances (including cash in the Capital Services Redemption Account), Exchequer deposits with commercial banks and other institutions, and investments in investment grade sovereign bills. For the purposes of the programme, NPRF liquid assets include the asset classes listed above, and also all marketable securities such as equities, government bonds and other listed investments. NPRF shares in domestic Irish banks, as well as the NPRF's non-liquid discretionary portfolio are excluded from the definition of liquid assets.

\footnotetext{
${ }^{3}$ As of November 2012, Exchequer tax receipts are comprised of income tax (including the universal social charge), value added tax (VAT), corporation tax, excise duties, stamp duties, capital gains tax, capital acquisitions, tax and customs duties and property tax (as from 2013).
} 
10. For the purposes of the programme, the ceiling on the central government net debt (indicative target) will be adjusted ${ }^{4}$

(i) upward by debt arising from payments for bank restructuring carried out under the programme's banking sector support and restructuring strategy. These payments may include, inter alia, loans to banks, investments in their equity (requited recapitalisation); unrequited recapitalisation; and purchases of troubled assets, which are carried out in line with programme objectives,

(ii) downward by the amount of proceeds from sales of bank equity held by the government or NPRF that are treated as Exchequer or NPRF receipts,

(iii) downward by the amount of receipts from disposals of state assets specified in the paragraph 21 of the MEFP dated 29 November 2012,

(iv) upward by the amount of these receipts spent on growth-enhancing projects not included in Budget 2013, up to no more than half of these receipts,

(v) upward for Exchequer contributions to the Resolution Fund for the resolution of credit institutions, and downward for any Exchequer recoupment, from the Resolution Fund, of such outlays.

(vi) upward for Exchequer contributions to the Credit Union Fund for the restructuring of credit unions up to $€ 250$ million cumulatively, and downward for any Exchequer recoupment, from the Credit Union Fund, of such outlays.

(vii) downward by the amount liquidated from the NPRF non-liquid discretionary portfolio,

(viii) downward (upward) by valuation gains (losses) in the NPRF liquid portfolio. The programme exchange rates will apply to all non-Euro denominated debt.

11. The ceiling on the outstanding stock of central government net debt will be adjusted upward (downward) by the amount of any final upward (downward) revision to the stock of end-June 2012 central government net debt.

\footnotetext{
${ }^{4}$ Although all payments related to the IBRC promissory notes are excluded from the Exchequer primary balance measure used for programme monitoring purposes, they are included in the Central Government net debt measure used for programme monitoring purposes.
} 


\begin{tabular}{lc}
\hline Central government net debt & (In billions of Euros) \\
\hline Outstanding stock: & 130.0 \\
End-September 2012 (provisional) & 135.5 \\
End-December 2012 (indicative target) & 143.1 \\
End-March 2013 (indicative target) & 149.2 \\
End-June 2013 (indicative target) & 150.4 \\
End-September 2013 (indicative target) & \\
\hline
\end{tabular}

\section{Non-accumulation of External Payments Arrears by Central Government}

12. The central government will accumulate no external payments arrears during the programme period. For the purposes of this performance criterion, an external payment arrear will be defined as a payment by the central government on its contracted or guaranteed external debt that has not been made within five business days after falling due, excluding any contractual grace period. The performance criterion will apply on a continuous basis.

13. The stock of external payments arrears of the central government will be calculated based on the schedule of external payments obligations reported by the National Treasury Management Agency.

\section{REPORTING REQUIREMENTS}

14. Performance under the programme will be monitored using data supplied to the EC, IMF, and ECB staffs. The Irish authorities will transmit promptly any data revisions.

- The Department of Finance will report to the EC, IMF and ECB staff, with a lag of no more than seven days after the test date the following data: the Exchequer primary balance, Exchequer tax revenues, payments for bank restructuring carried out under the programme's banking sector support and restructuring strategy, proceeds from sales of bank equity held by the government or NPRF that are treated as Exchequer receipts, receipts from disposals of state assets specified in the paragraph 21 of the MEFP dated 29 November 2012 and associated outlays on growth-enhancing projects not included in Budget 2013, Exchequer outlays for the resolution and restructuring of credit unions, any return of such outlays to the Exchequer and also for the recoupment of such outlays by the Exchequer from the Resolution Fund and the Restructuring and Stabilisation Fund.

- The National Treasury Management Agency will provide provisional figures on the outstanding stock of net government debt, including an unaudited analysis of NPRF holdings, with a lag of no more than seven days after the test date. The revised figures will be provided within three months of the test date.

- The National Treasury Management Agency will provide the final stock of the central government system external payments arrears to the EC, IMF and ECB staff, with a 
lag of not more than seven days after the arrears arise in accordance with the definition of external payments arrears as set forth in paragraph 12 of this memorandum.

- The Central Bank of Ireland will provide on a quarterly basis, bank by bank data on the assets of government guaranteed banks, including loans and provisioning by period overdue (90+days and less than 90 days) and category of borrower, 40 working days after the end of each quarter. 


\title{
Attachment IV. Ireland: Letter of Intent (European Commission)
}

Dublin, 29 November 2012

\author{
Mr. Mario Draghi \\ President \\ European Central Bank \\ Kaiserstrasse 29 \\ 60311 Frankfurt am Main
}

Germany

Mr. Jean-Claude Juncker

Eurogroup President

Ministère des Finances

3 , rue de la Congrégation

L-1352

Luxembourg

Mr. Olli Rehn

Vice-President of the European Commission responsible for Economic and Monetary Affairs and the euro

European Commission

BERL 10/299

B-1049 Brussels

Belgium

Mr Vassos Shiarly

Minister of Finance

Michael Karaoli \& Gregori Afxentiou

1439 Nicosia

Cyprus

Dear Messrs Draghi, Juncker, Rehn, and Shiarly

1. The Irish Government remains firmly committed to the programme, as illustrated by our continued strong performance in implementing the agreed policy frameworks and measures. This performance, and our preparation for Budget 2013, is against a backdrop of an increasingly adverse international economic environment. Nevertheless, yields on Irish government bonds have fallen dramatically in recent months, reflecting our strong performance as well as certain positive developments in Europe, especially the euro area 
leaders' June 29 commitment to decouple the sovereign and banking debt issues and in this context to specifically examine the situation of the Irish financial sector with the view of improving the sustainability of Ireland's well-performing adjustment programme. The ECB's decision on Outright Monetary Transactions is another positive development. These improved market conditions enabled the launch of our first bond issue under the programme in late July and the renewal of regular Treasury bill auctions. As we enter the final year of our 3yr programme, we are now focusing on the measures necessary to successfully exit from the programme. Notwithstanding the external risks, our policy efforts are aimed at further deepening our access to market funding during 2013, in order to exit from reliance on official financing. Timely implementation of euro area leaders' commitments would greatly support the effectiveness of these efforts. We are sure that we can rely on continued support of the external partners and fellow member states in this endeavour.

2. For the eighth review, we have once again met our commitments under the EU/IMF supported programme in terms of policy reforms as well as quantitative targets:

- As regards our fiscal consolidation objectives, the 2012 cumulative exchequer balance through end-September was ahead of the programme profile and, for 2012 as a whole, the general government deficit is projected to be below the $8.6 \%$ of GDP programme ceiling. We are alert to the overruns experienced in the health sector, and are taking structural measures to correct them in a durable manner. We will also present Budget 2013 to the Dail on December 5, which will underpin our commitment to reduce the general government deficit in 2013 and future years in line with our agreed programme consolidation path, despite the weaker growth outlook.

- We have introduced legislation to the Dail by end-September as envisaged, including measures to: (i) reform the personal insolvency framework; (ii) establish a Central Credit Register; (iii) strengthen the Credit Union legislative framework; and provide the legal basis for, respectively, (iv) the Irish Fiscal Advisory Council and (v) the medium-term expenditure ceilings (both introduced last year on an administrative basis). We have also launched an advisory service for distressed mortgage borrowers and introduced on a statutory basis (i) the requirement, under the terms of the Deposit Guarantee Scheme, for Credit Unions to maintain an amount in the Deposit Protection account in the central bank and (ii) a levy to fund the credit institutions resolution fund. Moreover, we progressed on reforming activation policies and preparing identified non-strategic state assets for eventual disposal, and reforming the sectoral wage setting mechanisms (legislation for which has been approved). Finally, we are taking necessary steps to introduce water meters, centralize the provision of water services and ensure a sound financial footing for Irish Water according to the timeline envisaged under the programme.

- The overarching strengthening, restructuring, and right-sizing of the domestic banking and the credit union sectors are also progressing according to plan. Two out of three PCAR banks are well advanced in reaching their end-2013 asset deleverage targets, and the Central Bank has formalized to the PCAR banks non-core asset 
deleverage targets and has introduced an advanced monitoring framework designed to ensure the banks take actions to improve net-stable-funding and liquidity coverage ratios. Revised restructuring plans for both AIB and PTSB have been submitted to the European Commission. Further actions to address loan arrears and unsustainable debts in banks' mortgage and SME loan portfolios are being implemented.

3. In light of our performance under the programme and our continued commitment to it, we request the completion of the eighth review and the release of the eighth EFSF/EFSM disbursement of EUR 0.8 billion.

4. In the attached seventh update of the Memorandum of Understanding of Specific Economic Policy Conditionality (the MOU), as well as in the Memorandum of Economic and Financial Policies (MEFP), we set out our plans to further advance towards meeting the objectives of our economic adjustment programme. We also continue to work with staff of the European Commission, the European Central Bank and the International Monetary Fund on the follow-up to the 29 June statement by the Heads of State and Government of the euro area.

5. We consider that delivering in full our commitments under the programme, while progressing towards severing the pernicious link between the banks and the sovereign, will enable Ireland to successfully exit the programme and return to sustained private market funding.

6. We are confident that the policies set forth in the Letters of Intent of 3 December 2010 and subsequent letters as well as this letter are adequate to achieve the objectives of our Programme. At the same time, while we do not envisage that revisions will be needed, we stand ready to take any corrective actions that may become appropriate if circumstances change. We will continue to consult with staff of the European Commission, the ECB, and the IMF on the adoption of such actions in advance in the event that revision of the policies contained in this Letter and the attached Memoranda becomes necessary.

7. This letter is being copied to Mme Lagarde.

Sincerely,

$/ \mathrm{s} /$

Michael Noonan, T.D.

Minister for Finance

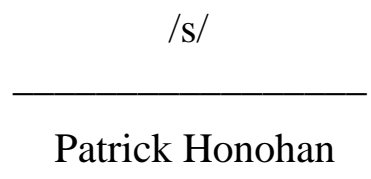

Governor of the Central Bank of Ireland 


\title{
Attachment V. Ireland: Memorandum of Understanding on Specific Economic Policy Conditionality (European Commission)
}

IRELAND

\author{
MEMORANDUM OF UNDERSTANDING \\ ON \\ Specific Economic Policy Conditionality
}

(SEVENTH UPDATE)

\section{[xx] January 2013}

1. With regard to Council Regulation (EU) $n^{\circ} 407 / 2010$ of 11 May 2010 establishing a European Financial Stabilisation Mechanism (EFSM), and in particular Article 3(5) thereof, this seventh update of the Memorandum of Understanding on Specific Economic Policy Conditionality (MoU) details the general economic policy conditions as embedded in Council Implementing Decision 2011/77/EU of 7 December 2010 on granting Union financial assistance to Ireland.

2. The quarterly disbursement of financial assistance from the $\mathrm{EFSM}^{1}$ will be subject to quarterly reviews of conditionality for the duration of the programme. Release of the installments will be based on observance of quantitative performance criteria, respect for EU Council Decisions and Recommendations in the context of the excessive deficit procedure (EDP), and a positive evaluation of progress made with respect to policy criteria in the Memorandum of Economic and Financial Policies (MEFP) and this updated MoU, which details and further specifies the criteria that will be assessed for the successive reviews up to the end of 2013. If targets are expected to be missed, additional action will be taken.

3. For the duration of the EU/IMF financial assistance programme the Irish authorities will take all the necessary measures to ensure a successful implementation of the programme and minimise the costs to the taxpayers, while protecting the most vulnerable. In particular, they commit to:

a. Rigorously implement fiscal policy consistent with the requirements of the excessive deficit procedure. In particular, the Department of Finance and

\footnotetext{
${ }^{1}$ On 28 November 2010 Eurogroup and ECOFIN Ministers issued a statement clarifying that euro-area and EU financial support will be provided on the basis of the programme which has been negotiated with the Irish authorities by the Commission and the IMF, in liaison with the ECB. Further to the Union support from the EFSM, loans from the EU and its Member States will include contributions from the European Financial Stability Facility (EFSF) and bilateral lending support from the United Kingdom, Sweden, and Denmark. The Loan Facility Agreements on these financing contributions will specify that the disbursements there under are subject to the compliance with the conditions of this Memorandum.
} 
the Department of Public Expenditure and Reform will continue to ensure effective tax collection and tight supervision of expenditure commitments by the line departments to ensure that the primary deficit target in cash (see Table 1 of MEFP and the Technical Memorandum of Understanding, TMU) and the general Government nominal budget deficit on ESA95 basis as set out in the EU Council Recommendation on excessive deficit procedures are achieved. Any additional unplanned revenues must be allocated to debt reduction. Moreover, the nominal value of Social Welfare pensions will not be increased.

b. Continue to strengthen the fiscal framework and reporting in line with EU requirements.

c. Use at least half of the proceeds from state asset sales for eventual debt reduction while also reinvesting the remainder of the total realised proceeds in projects which are of a commercial nature, meet ex-ante cost benefit criteria, enhance employment and preserve long term fiscal sustainability, including Programme and EDP fiscal targets.

d. Continuously monitor financial markets to exploit opportunities to return to commercial funding as soon as possible.

e. Ensure that activation services are enhanced, to tackle the high and persistent rate of long-term unemployment. In particular, the Department of Social Protection will take steps to improve the ratio of vacancies filled off the live register, focus on re-training the unemployed to reduce the risk of long-term unemployment and ensure appropriate incentives through the implementation of sanctions. Generally, the government will advance its plans to introduce new activation measures building on Pathways to Work (the government's strategy for institutional reform of the activation system).

f. Ensure that no further exemptions to the competition law framework will be granted unless they are entirely consistent with the goals of the EU/IMF Programme and the needs of the economy.

g. Ensure that NAMA: (i) maintains the highest standards of governance with appropriate accountability and transparency arrangements; (ii) reduces the costs of its operations; and (iii) constructively contributes to the restoration of the Irish property market in the course of meeting the asset disposal targets established and monitored by the NAMA Board, including redemption of $€ 7.5$ billion worth of senior bonds by end 2013.

h. Ensure that the restructuring of credit unions will underpin the financial stability and long term sustainability of the sector. The restructuring will be completed in as short a timeframe as possible under a clear plan identifying credit unions appropriate for restructuring, subject to Central 
Bank regulatory approval. As regards funding, the first call should be on the credit unions concerned or the sector as a whole; any Exchequer funding should be minimised, should be provided only in the context of a restructuring plan in compliance with EU state aid rules, and should be recouped from the sector over time. In parallel, the Central Bank will continue its inspections to determine the financial condition of the weakest credit unions, and will engage its resolution powers as needed, drawing on Resolution Fund resources if required.

i. Ensure continued compliance with the minimum Core Tier 1 Capital ratio of $10.5 \%$ for all PCAR banks (AIB, BOI, and PTSB).

j. Consult ex-ante with the European Commission, the ECB and the IMF on the adoption of policies that are not included in this Memorandum but that could have a material impact on the achievement of programme objectives.

4. To facilitate programme monitoring, the authorities will provide the European Commission, the ECB and the IMF with:

a. All information required to monitor progress during programme implementation and to track the economic and financial situation.

b. A compliance report on the fulfillment of the conditionality prior to the release of the installments.

c. Reliable and regular availability of budgetary and other data as detailed in Annex 1.

\section{Actions for the ninth review (actions to be completed by end Q4-2012)}

\section{Fiscal consolidation}

5. The Government will publish a budget for 2013 consistent with a general government deficit ceiling of $7.5 \%$ of GDP and in line with the Council Recommendations under Ireland's excessive deficit procedure.

6. On the basis of the aggregate budgetary projections set out in the Medium Term Fiscal Statement (MTFS) of November 2011, consolidation measures for 2013 will amount to at least $€ 3.5$ billion. The following measures are proposed for 2013 on the basis of the MTFS:

- Revenue measures to raise at least $€ 1.25$ billion $^{2}$, including:

\footnotetext{
${ }^{2}$ Inclusive of carryover from 2012.
} 
- A broadening of personal income tax base.

- A value-based property tax.

- A restructuring of motor taxation.

- A reduction in general tax expenditures.

- An increase in excise duty and other indirect taxes.

- Expenditure reductions necessary to achieve an upper limit on voted expenditure of $€ 54.3$ billion, which will involve deficit consolidation measures of $€ 2.25$ billion on the basis of the MTFS, including:

- Social expenditure reductions.

- Reduction in the total pay and pensions bill.

- Other programme expenditure, and reductions in capital expenditure.

7. Without prejudice to the minimum consolidation amount referred to in the previous paragraph and to the requirements to achieve the agreed fiscal targets, the Government may, in consultation with the staff of the European Commission, the IMF, and the ECB, substitute one or more of the above measures with others of equally good quality based on the options identified in the Comprehensive Review of Expenditure (CRE).

8. The authorities will take the measures necessary to unwind the overrun in health spending and will contain health expenditure next year to within the $€ 13.6$ billion departmental ceiling for 2013 set in the Comprehensive Expenditure Report 2012-14.

9. Government will publish a medium-term fiscal statement covering the period 20132015 consistent with a further reduction of the General Government deficit in line with the fiscal targets set out in the Council Recommendation in the context of the excessive deficit procedure.

10. DPER and DECLG will agree a protocol to ensure that the local government sector continues to be managed in balance over the medium term and in particular to ensure a balanced budget in 2013, by reference to the application of the financial management safeguards and requirements in place within the sector. 


\section{Financial sector reforms}

\section{Capital assessment}

11. The authorities will provide the staff of the European Commission, the ECB and the IMF a review of developments in the PCAR banks relative to PCAR 2011. Overall results of this work will be published by end January 2013. The authorities will agree with the staff of the European Commission, the ECB and the IMF on the specific details of the review.

\section{Deleveraging}

12. The authorities, in consultation with the staff of the European Commission, the IMF, and the ECB, will assess banks' deleveraging based on the existing nominal targets for disposal and run-off of non-core assets in line with the 2011 Financial Measures Programme. Fire sales of assets will be avoided, as will any excessive deleveraging of core portfolios, so as not to impair the flow of credit to the domestic economy.

\section{Funding and liquidity monitoring}

13. The authorities will provide staff of the European Commission, the IMF, and the ECB with a detailed assessment of banks' progress towards the relevant Basel III requirements using the advanced monitoring framework.

\section{Asset quality}

14. The authorities will provide staff of the European Commission, the IMF, and the ECB with their assessment of banks' performance with the work-out of their non-performing mortgage portfolios in accordance with the agreed key performance indicators. A set of key performance indicators for SMEs will also be developed. The authorities will monitor each PCAR bank's performance relative to already-defined key performance indicators for progress in resolving problem loans, and also against bank specific targets for reviewing new and existing individual arrears cases.

15. The authorities will publish banks' reported data on loan modifications, including redefaults of modified loans, to permit analysis of the effectiveness of alternative resolution approaches in improving debt service performance.

\section{Reorganisation}

16. The authorities will report on progress in implementing the strategy for the reorganisation of Irish credit institutions, including any steps to strengthen the credit union sector, and discuss it together with the staff of the European Commission, the IMF, and the ECB. 


\section{Financial Supervision}

17. The authorities will present a comprehensive report on progress in implementing the Central Bank of Ireland's action plan for strengthening supervision of credit institutions and discuss it together with the staff of the European Commission, the ECB and the IMF.

18. The authorities will report on banks' progress with the implementation of their strategies to address loan arrears and unsustainable debts in banks' mortgage and SME loan portfolios.

19. The authorities will continue enhancing their approach to Credit Risk, risk weighted asset (RWA) supervision including conducting annual model performance reviews, assessing RWA calculation and reviewing banks' approaches to RWA forecasting and stress testing in advance of PCAR 2013. The authorities will complete the reviews and issue mitigating actions for the banks concerned.

\section{Personal Insolvency Reform}

20. The authorities will ensure that the Draft Personal Insolvency Bill will provide for the framework for the appropriate licensing and regulation of Personal Insolvency Practitioners.

\section{Structural reforms}

\section{Enhancing access to finance for SMEs}

21. The authorities will report on a survey of SMEs demand for credit covering the six months to September 2012. This will include whether or not SMEs sought credit, approval/refusal rates, conditions and criteria attached to approvals, reasons for refusals and information on use of non-bank finance, turnover, profitability and employment levels. In addition, the authorities will complete a separate study assessing the effectiveness of the Credit Review Office to ensure that SMEs are getting the support on bank lending they require.

22. The authorities will also improve the efficiency of the corporate insolvency framework for SMEs, drawing on the recommendations in the recent report by the Company Law Review Group. In particular, the authorities will prepare amendments to designate the Circuit Courts as competent for the examinership of companies within the EU small company thresholds (e.g., balance sheet below $€ 4.4$ million).

\section{Competition}

23. On the basis of a report on developments to be provided by the authorities by end Q4 2012, the authorities, in consultation with staff of the European Commission, IMF and the ECB, will review whether sufficient progress has been made toward the goal of strengthening competition law enforcement by ensuring the availability of effective sanctions for 
infringements of Irish competition law and Articles 101 and 102 of the Treaty on the Functioning of the European Union and the functioning of the Competition Authority, and whether additional measures will be required.

State asset disposals

24. Government will complete, if necessary, relevant regulatory, legislative, corporate governance and financial reforms required to bring to the point of sale the assets it has identified for disposal. For each asset and/or group of assets, the government will provide a report to the staff of the European Commission, the IMF, and the ECB on progress achieved and remaining steps towards to the point of sale.

Water services reform

25. The authorities will ensure assignment of economic regulatory oversight over the water sector, including price setting powers, is provided for by way of legislation to the Commission for Energy Regulation. The Government will also ensure that interim arrangements are in place for the establishment of Irish Water.

\section{Actions for the tenth review (actions to be completed by end Q1-2013)}

\section{Financial sector reforms}

\section{Capitalisation}

26. The authorities will report on the evolution of regulatory capital within the PCAR banks up to the end of December 2012, and will present and discuss their findings with the staff of the European Commission, the IMF, and the ECB.

\section{Deleveraging}

27. The authorities, in consultation with the staff of the European Commission, the IMF, and the ECB, will assess banks' deleveraging based on the existing nominal targets for disposal and run-off of non-core assets in line with the 2011 Financial Measures Programme. Fire sales of assets will be avoided, as will any excessive deleveraging of core portfolios, so as not to impair the flow of credit to the domestic economy.

\section{Funding and liquidity monitoring}

28. The authorities will provide staff of the European Commission, the IMF, and the ECB with a detailed assessment of banks' progress towards the relevant Basel III requirements using the advanced monitoring framework. 
29. Following finalisation of the Capital Requirements Directive legislative text, the authorities will establish draft guidance for the creation and subsequent holding of liquidity buffers by banks for issue in advance of the entry into force of the regulations.

30. In addition, the authorities will monitor the liquidity buffers held by banks in accordance with the Capital Requirements Regulation.

\section{Asset quality}

31. The authorities will provide staff of the European Commission, the IMF, and the ECB with their assessment of banks' performance with the work-out of their non-performing mortgage and SME portfolios in accordance with the agreed key performance indicators. The authorities will monitor each PCAR bank's performance relative to already-defined key performance indicators for progress in resolving problem loans, and also against bank specific targets for reviewing new and existing individual arrears cases.

32. The authorities will publish banks' reported data on loan modifications, including redefaults of modified loans, to permit analysis of the effectiveness of alternative resolution approaches in improving debt service performance.

33. Having secured adequate protections for debtors' principal private residence through the enactment of the Personal Insolvency Bill, the authorities will introduce legislation remedying the issues identified by case law in the 2009 Land and Conveyancing Law Reform Act, so as to remove unintended constraints on banks to realise the value of loan collateral under certain circumstances.

\section{Reorganisation}

34. The authorities will report on progress in implementing the strategy for the reorganisation of Irish credit institutions, including any steps to strengthen the credit union sector, and discuss it with the staff of the European Commission, the IMF, and the ECB.

\section{Financial supervision}

35. The authorities will present a comprehensive report on progress in implementing the Central Bank of Ireland's action plan for strengthening supervision of credit institutions and discuss it with the staff of the European Commission, the IMF, and the ECB.

36. The authorities will report on banks' progress with the implementation of their strategies to address loan arrears and unsustainable debts in banks' mortgage, and SME loan portfolios.

37. The authorities will ensure appropriately prudent provisioning treatment of loan modifications. The authorities will continue to engage with banks and review the proposed provisioning treatment for all advanced loan modification products being introduced as part 
of their mortgage arrears resolution strategies. In addition, the authorities will, in consultation with staff of the EC, ECB, and the IMF, update where necessary the 2011 Impairment Provisioning and Disclosure guidelines setting out the appropriate assumptions for all categories of advanced loan modifications.

\section{Structural reforms}

\section{Health sector}

38. The authorities will conduct a study to compare the cost of drugs, prescription practices and the usage of generics in Ireland with comparable EU jurisdictions.

\section{Efficient social support expenditure}

39. The authorities will complete by end January a review of the labour market activation policies in place to enable the unemployed to return to active employment against the targets set out in the 'Pathways to Work' plan, with a view to increasing the impact of the interventions made and services provided in this key area through; implementing key service elements such as profile-based activation in all offices; extending one-stop shops to more offices, bringing forward necessary steps to outsource training and activation, and broadening coverage of policy initiatives to long-term unemployed.

\section{Actions for the eleventh review (actions to be completed by end Q2-2013)}

\section{Financial sector reforms}

\section{Capital assessment}

40. The authorities will agree with the staff of the European Commission, the ECB and IMF on the specific features of the methodology for the PCAR 2013 stress test exercise.

\section{Deleveraging}

41. The authorities, in consultation with the staff of the European Commission, the IMF, and the ECB, will assess banks' deleveraging based on the existing nominal targets for disposal and run-off of non-core assets in line with the 2011 Financial Measures Programme. Fire sales of assets will be avoided, as will any excessive deleveraging of core portfolios, so as not to impair the flow of credit to the domestic economy.

\section{Funding and liquidity monitoring}

42. The authorities will provide staff of the European Commission, the IMF, and the ECB with a detailed assessment of banks' progress towards the relevant Basel III requirements using the advanced monitoring framework. 
43. The authorities will also monitor the liquidity buffers held by banks in accordance with the Capital Requirements Regulation.

\section{Asset quality}

44. The authorities will provide staff of the European Commission, the IMF, and the ECB with their assessment of banks' performance with the work-out of their non-performing mortgage and SME portfolios in accordance with the agreed key performance indicators. The authorities will monitor each PCAR bank's performance relative to already-defined key performance indicators for progress in resolving problem loans, and also against bank specific targets for reviewing new and existing individual arrears cases.

45. The authorities will publish banks' reported data on loan modifications, including redefaults of modified loans, to permit analysis of the effectiveness of alternative resolution approaches in improving debt service performance.

46. The authorities will undertake a review of progress in addressing mortgage arrears.

\section{Reorganisation}

47. The authorities will report on progress in implementing the strategy for the reorganisation of Irish credit institutions, including any steps to strengthen the credit union sector, and discuss it together with the staff of the European Commission, the IMF, and the ECB.

\section{Financial supervision}

48. The authorities will present a comprehensive report on progress in implementing the Central Bank of Ireland's action plan for strengthening supervision of credit institutions and discuss it together with the staff of the European Commission, the IMF, and the ECB.

49. The authorities will report on banks' progress with the implementation of their strategies to address loan arrears and unsustainable debts in banks' mortgage, and SME loan portfolios.

50. The authorities will review the implementation of the 2011 CBI Provisioning and Disclosure guidelines by the covered banks with reference to the end-2012 published financial statements.

51. Upon publication of the EU directive establishing a framework for the recovery and resolution of credit institutions and investment firms, the authorities will review the Resolution fund levy regulation. 


\section{Structural reforms}

State assets

52. The authorities will report to the staff of the European Commission, the IMF, and the ECB on the quantum of the proceeds of any realised asset sales to date. For assets yet to be disposed, the authorities will report on progress made and remaining steps.

\section{Labour market reform}

53. The authorities will report to the staff of the European Commission, the IMF, and the ECB on the impact on the labour market of reforms to sectoral wage-setting mechanisms undertaken under the programme.

Water services reform

54. The Commission for Energy Regulation will carry out consultations to determine the framework for household water charges with a view to start charging by the end of the EUIMF programme period. The CER will also conduct consultations in due course to determine the pricing methodology for the non-domestic sector.

55. The Government will publish a Water Services Bill with the aim of defining the regulatory framework for the water sector under a national public utility setting and providing for the establishment of Irish Water in its final form. There will be prior engagement with the European Commission as appropriate, in developing the legislative arrangements.

\section{Actions for the twelfth review (actions to be completed by end Q3-2013)}

\section{Financial sector reforms}

\section{Capital assessment}

56. The authorities will complete the PCAR 2013. Building on the outcomes from PCAR 2011 and the FMP 2012, the authorities will conduct another rigorous stress test and this will continue to be based on robust loan-loss forecasts and a high level of transparency. This stress test will draw on an assessment of the banks' calculation of risk weighted assets, loan loss forecasting, and capital modelling. Before publication, the results of the PCAR 2013 will be discussed with the staff of European Commission, the IMF, and the ECB and will be aligned with the timing of the next EBA exercise. The results and methodology will be published in full and on a bank-by-bank basis, and the authorities will accordingly ensure that banks are adequately capitalised. 
57. The authorities will report on the evolution of regulatory capital up to the end of June 2013 within the banks covered by the PCAR and will present and discuss their findings with the staff of the European Commission, the IMF, and the ECB.

\section{Deleveraging}

58. The authorities, in consultation with the staff of the European Commission, the IMF, and the ECB, will assess banks' deleveraging based on the existing nominal targets for disposal and run-off of non-core assets in line with the 2011 Financial Measures Programme. Fire sales of assets will be avoided, as will any excessive deleveraging of core portfolios, so as not to impair the flow of credit to the domestic economy.

\section{Funding and liquidity monitoring}

59. The authorities will provide staff of the European Commission, the IMF, and the ECB with a detailed assessment of banks' progress towards the relevant Basel III requirements using the advanced monitoring framework.

\section{Asset quality}

60. The authorities will provide staff of the European Commission, the IMF, and the ECB with their assessment of banks' performance with the work-out of their non-performing mortgage and SME portfolios in accordance with the agreed key performance indicators. The authorities will monitor each PCAR bank's performance relative to already-defined key performance indicators for progress in resolving problem loans, and also against bank specific targets for reviewing new and existing individual arrears cases.

61. The authorities will publish banks' reported data on loan modifications, including redefaults of modified loans, to permit analysis of the effectiveness of alternative resolution approaches in improving debt service performance.

\section{Reorganisation}

62. The authorities will report on progress in implementing the strategy for the reorganisation of Irish credit institutions, including any steps to strengthen the credit union sector, and discuss it together with the European Commission, the IMF, and the ECB.

\section{Financial Supervision}

63. The authorities will present a comprehensive report on progress in implementing the Central Bank of Ireland's action plan for strengthening supervision of credit institutions and discuss it together with the staff of the European Commission, the IMF, and the ECB. 
64. The authorities will report on banks' progress with the implementation of their strategies to address loan arrears and unsustainable debts in banks' mortgage and SME loan portfolios.

\section{Structural reforms}

Access to SME credit

65. Based on experience of the operation of the Insolvency Service in the personal insolvency reform, the authorities will consider the appropriateness of further enhancements to the company law framework to reduce costs and achieve efficiency gains, including the potential for an administrative body to facilitate SME restructuring.

Water services reform

66. The Government's budgetary perspective will be based on Irish Water becoming substantially self-funded over time.

\section{Actions for the thirteenth review (actions to be completed by end Q4-2013)}

\section{Financial sector reforms}

\section{Deleveraging}

67. The authorities will produce a final report of the banks' implementation of their deleveraging plans under the PLAR 2011. Their compliance with the asset disposal and runoff targets in nominal value terms will be discussed with the staff of the European Commission, the IMF, and the ECB.

68. The authorities will produce a final report on progress towards compliance with Basel III liquidity and funding requirements by the relevant dates.

69. The authorities will also monitor the liquidity buffers held by banks in accordance with the Capital Requirements Regulation.

\section{Asset quality}

70. The authorities will provide staff of the European Commission, the IMF, and the ECB with their assessment of banks' performance with the work-out of their non-performing mortgage and SME portfolios in accordance with the agreed key performance indicators. The authorities will monitor each PCAR bank's performance relative to already-defined key performance indicators for progress in resolving problem loans, and also against bank specific targets for reviewing new and existing individual arrears cases. 
71. The authorities will publish banks' reported data on loan modifications, including redefaults of modified loans, to permit analysis of the effectiveness of alternative resolution approaches in improving debt service performance.

\section{Reorganisation}

72. The authorities will provide a final report on progress in implementing the strategy for the reorganisation of Irish credit institutions, including any steps to strengthen the credit union sector, and discuss it together with the European Commission, the IMF, and the ECB.

\section{Financial Supervision}

73. The authorities will present a final comprehensive report on progress in implementing the Central Bank of Ireland's action plan for strengthening supervision of credit institutions and discuss it together with the European Commission, the IMF, and the ECB.

74. The authorities will provide a final report on banks' progress with the implementation of their strategies to address loan arrears and unsustainable debts in banks' mortgage, and SME loan portfolios.

75. The authorities will ensure that the Central Credit Register is operational. 


\section{Annex 1. Provision of data}

During the programme, the following indicators and reports shall be made available to the staff of the European Commission, the IMF, and the ECB by the Irish authorities on a regular basis. The External Programme Compliance Unit (EPCU) of the Department of Finance will coordinate and collect data and information and forward to the staff of the European Commission, the IMF, and the ECB.

\begin{tabular}{|c|c|c|}
\hline \multicolumn{3}{|c|}{$\begin{array}{l}\text { To be provided by the Department of Finance in consultation with the Department of Public } \\
\text { Expenditure and Reform as appropriate }\end{array}$} \\
\hline Ref. & Report & Frequency \\
\hline F.1 & $\begin{array}{l}\text { Monthly data on adherence to budget targets (Exchequer } \\
\text { statement, details on Exchequer revenues and expenditure with } \\
\text { information on Social Insurance Fund to follow as soon as } \\
\text { practicable). }\end{array}$ & $\begin{array}{l}\text { Monthly, } 10 \text { days after } \\
\text { the end of each month }\end{array}$ \\
\hline F.2 & $\begin{array}{l}\text { Updated monthly report on the Exchequer Balance and General } \\
\text { Government Balance outlook for the remainder of the year which } \\
\text { shows transition from the Exchequer Balance to the General } \\
\text { Government Balance (using presentation in Table } 1 \text { and Table 2A } \\
\text { of the EDP notification). }\end{array}$ & $\begin{array}{l}\text { Monthly, } 20 \text { days after } \\
\text { the end of each month }\end{array}$ \\
\hline F.3 & $\begin{array}{l}\text { Quarterly data on main revenue and expenditure items of local } \\
\text { Government. }\end{array}$ & $\begin{array}{l}\text { Quarterly, } 90 \text { days } \\
\text { after the end of each } \\
\text { quarter }\end{array}$ \\
\hline F.4 & $\begin{array}{l}\text { Quarterly data on the public service wage bill, number of } \\
\text { employees and average wage (using the presentation of the Pay } \\
\text { and Pension Bill with further details on pay and pension costs of } \\
\text { local authorities). }\end{array}$ & $\begin{array}{l}\text { Quarterly, } 30 \text { days } \\
\text { after the end of each } \\
\text { quarter }\end{array}$ \\
\hline F.5 & $\begin{array}{l}\text { Quarterly data on general Government accounts, and general } \\
\text { Government debt as per the relevant EU regulations on statistics. }\end{array}$ & $\begin{array}{l}\text { Quarterly accrual data, } \\
90 \text { days after the end of } \\
\text { each quarter }\end{array}$ \\
\hline F.6 & $\begin{array}{l}\text { Updated annual plans of the general Government balance and its } \\
\text { breakdown into revenue and expenditure components for the } \\
\text { current year and the following four years, using presentation in the } \\
\text { stability programme's standard table on general Government } \\
\text { budgetary prospects. }\end{array}$ & $\begin{array}{l}30 \text { days after EDP } \\
\text { notifications }\end{array}$ \\
\hline F.7 & $\begin{array}{l}\text { Data on short- and medium- /long-term debt falling due (all } \\
\text { instruments) over the next } 36 \text { months (interest and amortisation) } \\
\text { for Non-Commercial State Agencies }\end{array}$ & $\begin{array}{l}\text { Quarterly, } 30 \text { working } \\
\text { days after the end of } \\
\text { each quarter }\end{array}$ \\
\hline F.8 & $\begin{array}{l}\text { Data on short- and medium- /long-term debt falling due (all } \\
\text { instruments) over the next } 36 \text { months (interest and amortisation) } \\
\text { for local authorities }\end{array}$ & $\begin{array}{l}\text { Quarterly, } 30 \text { working } \\
\text { days after the end of } \\
\text { each quarter }\end{array}$ \\
\hline F.9 & $\begin{array}{l}\text { Data on short- and medium- /long-term debt falling due (all } \\
\text { instruments) over the next } 36 \text { months for State- owned } \\
\text { commercial enterprises (interest and amortisation) }\end{array}$ & $\begin{array}{l}\text { Quarterly, } 30 \text { working } \\
\text { days after the end of } \\
\text { each quarter }\end{array}$ \\
\hline F.10 & $\begin{array}{l}\text { Assessment report of the management of activation policies and } \\
\text { on the outcome of job seekers' search activities and participation } \\
\text { in labour market programmes. }\end{array}$ & $\begin{array}{l}\text { Quarterly, } 30 \text { working } \\
\text { days after the end of } \\
\text { each quarter. }\end{array}$ \\
\hline \multicolumn{3}{|c|}{ To be provided by the NTMA } \\
\hline N.1 & $\begin{array}{l}\text { Monthly information on the central Government's cash position } \\
\text { with indication of sources as well of number of days covered }\end{array}$ & $\begin{array}{l}\text { Monthly, three } \\
\text { working days after the } \\
\text { end of each month }\end{array}$ \\
\hline N.2 & Data on below-the-line financing for central Government. & $\begin{array}{l}\text { Monthly, no later than } \\
15 \text { working days after }\end{array}$ \\
\hline
\end{tabular}




\begin{tabular}{|c|c|c|}
\hline & & the end of each month \\
\hline N.3 & Data on the National Debt & $\begin{array}{l}\text { Monthly, } 15 \text { working } \\
\text { days after the end of } \\
\text { each month }\end{array}$ \\
\hline N.4 & $\begin{array}{l}\text { Data on short-, medium- and long-term debt falling due (all } \\
\text { instruments) over the next } 36 \text { months (interest and amortisation) } \\
\text { for the National Debt. }\end{array}$ & $\begin{array}{l}\text { Monthly, } 30 \text { working } \\
\text { days after the end of } \\
\text { each month }\end{array}$ \\
\hline N.5 & $\begin{array}{l}\text { Updated estimates of financial sources (bonds issuance, other } \\
\text { financing sources) for the Exchequer Borrowing Requirement / } \\
\text { National Debt in the next } 12 \text { months }\end{array}$ & $\begin{array}{l}\text { Monthly, } 30 \text { working } \\
\text { days after the end of } \\
\text { each month }\end{array}$ \\
\hline \multicolumn{3}{|c|}{ To be provided by the Central Bank of Ireland } \\
\hline C.1 & The Central Bank of Ireland's balance sheet. & $\begin{array}{l}\text { Weekly, next working } \\
\text { day }\end{array}$ \\
\hline C.2 & $\begin{array}{l}\text { Individual maturity profiles (amortisation only) for each of the } \\
\text { domestic banks will be provided as of the last Friday of each } \\
\text { month. }\end{array}$ & $\begin{array}{l}\text { Monthly, } 30 \text { working } \\
\text { days after each month } \\
\text { end. }\end{array}$ \\
\hline C.3 & $\begin{array}{l}\text { Detailed financial and regulatory information (consolidated data) } \\
\text { on domestic individual Irish banks and the banking sector in total } \\
\text { especially regarding profitability (P\&L), balance sheet, asset } \\
\text { quality, regulatory capital; PLAR funding plan forecasts including } \\
\text { LDR, NSFR and LCR outturns and forecasts. }\end{array}$ & $\begin{array}{l}\text { Quarterly, } 40 \text { working } \\
\text { days after the end of } \\
\text { each quarter }\end{array}$ \\
\hline C.4 & $\begin{array}{l}\text { Detailed information on deposits for the last Friday of each } \\
\text { month. }\end{array}$ & $\begin{array}{l}\text { Monthly, } 30 \text { working } \\
\text { days after each month } \\
\text { end. }\end{array}$ \\
\hline C.5 & $\begin{array}{l}\text { Data on liabilities covered under the ELG Scheme for each of the } \\
\text { Covered Institutions. }\end{array}$ & $\begin{array}{l}\text { Monthly, } 30 \text { working } \\
\text { days after each month } \\
\text { end. }\end{array}$ \\
\hline C.6 & $\begin{array}{l}\text { Deleveraging committee minutes from the banks and deleveraging } \\
\text { sales progress sheets, detailing pricing, quantum, and other } \\
\text { relevant result metrics. }\end{array}$ & $\begin{array}{l}\text { Monthly, reflecting } \\
\text { committee meetings } \\
\text { held each month }\end{array}$ \\
\hline C.7 & $\begin{array}{l}\text { Deleveraging reports including (i) progress achieved towards } \\
\text { deleveraging in line with the } 2011 \text { Financial Measures } \\
\text { Programme; and (ii) actual and planned asset disposals. }\end{array}$ & $\begin{array}{l}\text { Quarterly, } 40 \text { working } \\
\text { days after the end of } \\
\text { the reference period. }\end{array}$ \\
\hline
\end{tabular}




\title{
INTERNATIONAL MONETARY FUND
}

\author{
IRELAND
}

\section{Eighth Review Under the Extended Arrangement—Supplementary Information}

Prepared by the European Department

(In consultation with other departments)

\section{Approved by Ajai Chopra and Lorenzo Giorgianni}

December 11, 2012

1. This supplement provides an update on economic and policy developments since the issuance of the staff report on December 3, 2012 (EBS/12/157). Budget 2013 was submitted to Parliament on December 5 and includes a $€ 3.5$ billion consolidation for 2013, meeting the prior action for this review.

\section{Fiscal performance weakened in November, but the 2012 fiscal targets are not at} risk. The cumulative exchequer primary balance (excluding some 2011 corporation tax proceeds received in 2012) through end-November 2012 was -5.5 percent of GDP, 0.1 percent of GDP under the authorities' profile, but 1.4 percent of GDP higher than the balance obtaining over the same period last year. Tax revenues (including Pay Related Social Insurance (PRSI)) disappointed in November, the largest revenue month of the year, with a large underperformance in income tax returns by the self-employed outweighing continued VAT over performance. Even after incorporating the 0.2 percent of GDP in higher proceeds

Cumulative Exchequer Out-Turn Vs. Authorities' Profile - January-November 2012
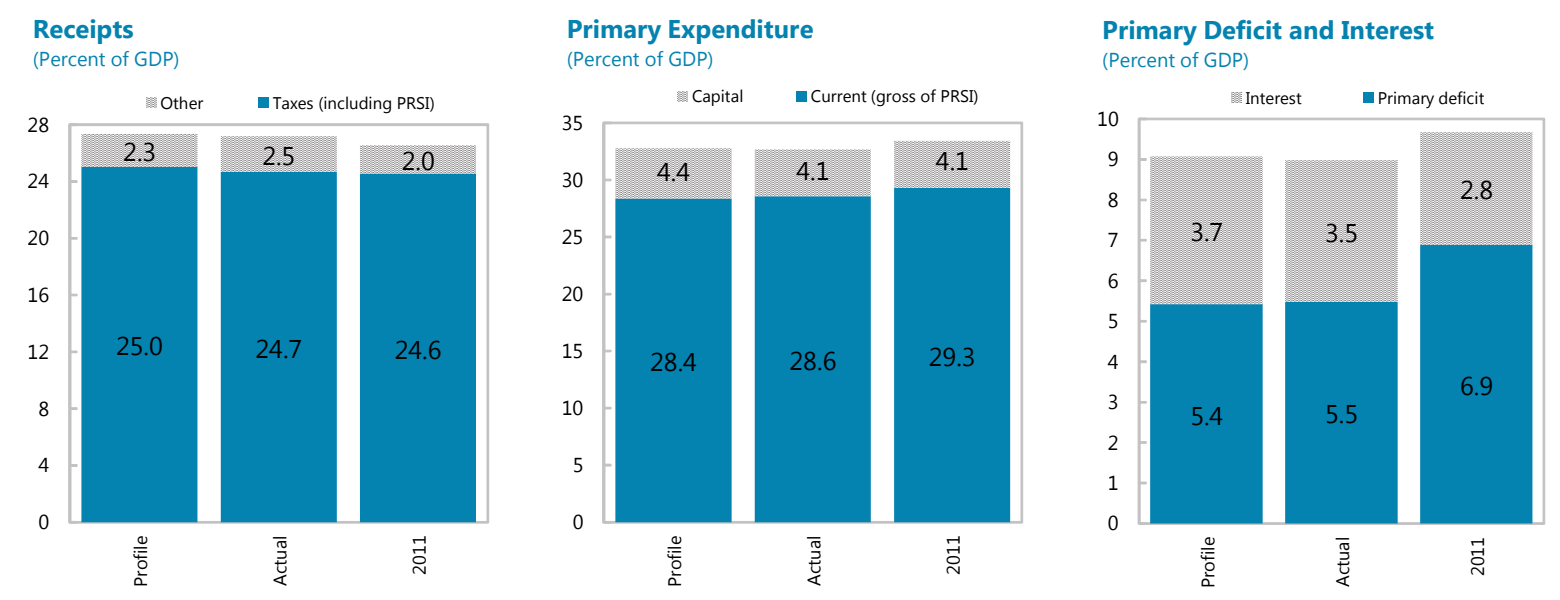

Sources: Department of Finance; and IMF staff estimates.

PS: To facilitate comparability, (i) the $€ 251$ million corporation tax payment delayed from December 2011 into January 2012 is excluded from both the 2012 tax profile and outturn; (ii) the $€ 553$ million in interest payments met in Jan-Nov 2011 via drawdown of the Capital Services Redemption Account (CSRA) are included in the 2011 exchequer interest bill; (iii) symmetric entries of $€ 646$ million in respect of the Sinking Fund in March $2012 \mathrm{r}$ - recorded as current spending and other receipts (capital receipts) - are taken out; (iv) the IBRC promissory note payment of $€ 3.06$ billion that was settled through bond issuance is included in capital expenditure for 2012; (v) the ILP payment of $€ 1.3$ billion is excluded from 2012 capital spending; and (vi) about $€ 1$ billion in one-off proceeds arising from the sale of the state's shareholding in BoI is excluded from 2011 other receipts; (vii) theJuly 2011 bank recapitalization costs of $€ 7.6$ billion are excluded from non-voted capital spending for 2011; and (viii) the UMTS license sale proceeds are included in November 2012. 
from the recent telecom license sale, aggregate revenues are now about $1 / 4$ percent of GDP lower than expected during the review mission, although December revenues could narrow this shortfall. ${ }^{1}$ The current expenditure over-runs, led by health and social protection, have stabilized at 0.2 percent of GDP, and continue to be offset by capital underspends. Given that the performance criteria are adjusted for revenue deviations from projections to protect against cyclical factors, the end-December 2012 targets are not at risk. The 2012 general government balance target of 8.6 percent of GDP for 2012 should also be achieved by a margin of at least $1 / 4$ percent of GDP.

\section{Budget 2013 includes concrete and durable measures to achieve the} programmed consolidation of $€ 3.5$ billion in order to reach the general government deficit ceiling of 7.5 percent of GDP, consistent with MEFP ( $\mid 6$ ). The new tax and current spending measures announced amount to $€ 1.2$ billion and $€ 1.7$ billion, respectively, after excluding carry-overs from policies implemented in previous years, capital savings specified in November 2011, and savings expected in the form of higher dividends from state-owned enterprises, while including additional measures to unwind the health spending pressures that emerged in 2012.

\begin{tabular}{|crr|}
\hline Composition of 2013 Fiscal Consolidation & $\begin{array}{r}\text { Eercent } \\
\text { of GDP }\end{array}$ \\
\hline Programmed Consolidation in 2013 & 3.5 & 2.1 \\
Less: $\quad$ Capital savings previously announced & -0.5 & -0.3 \\
Carryover from measures in previous years & -0.6 & -0.4 \\
Revenue & -0.2 & -0.1 \\
Current expenditure & -0.4 & -0.3 \\
Additional dividends from state-owned enterprises & -0.1 & -0.1 \\
Add: $\quad$ Measures to offset health spending pressures & 0.7 & 0.4 \\
"New" consolidation measures announced in Budget 2013 & 2.9 & 1.7 \\
Revenue measures & 1.2 & 0.7 \\
Current expenditure (net of fees and charges) & 1.7 & 1.0 \\
\hline
\end{tabular}

\section{The revenue package features a significant broadening of the tax base, while} selected increases in tax rates avoid higher marginal rates on labor income. Key base broadening steps include (i) introducing a property tax for home owners, set at the rate of 0.18 percent of self-assessed value, with a higher rate for houses valued above $€ 1$ million; (ii) removing the exemption of the first $€ 127$ of weekly earnings for employee PRSI;

(iii) subjecting unearned income to PRSI; (iv) capping of tax relief benefiting contributors to private pension funds to a level that delivers pension income of $€ 60,000$ or less; (v) removing the universal social charge subsidy for persons over 70 years old with an annual pension above $€ 60,000$; and (vi) expanding the carbon tax base to include solid fuels. A 3 percentage

\footnotetext{
${ }^{1}$ These figures for the exchequer primary balance and revenues include $€ 0.45$ billion proceeds from the telecom license sale in November - above the budget of $€ 0.15$ billion - even though they will be banked in December.
} 
point increase in the capital gains and deposit interest retention tax rates is expected to be progressive. Indirect taxes increase on alcohol (first rise in a decade), tobacco, and vehicles. The package also includes measures to stimulate the economy, such as a one-off permission until 2015 for early withdrawal of up to 30 percent of additional voluntary contributions to pension funds, together with tax reliefs targeted at house purchasers and small and medium enterprises, including start ups and those undertaking research and development.

\begin{tabular}{|lrr|}
\hline \multicolumn{2}{|c|}{ Savings from New Fiscal Measures Announced in Budget 2013} \\
\hline (in € bn) & Yield in 2013 & Full year effect \\
\hline Revenue & 1.21 & 1.70 \\
Pay-related social insurance & 0.29 & 0.34 \\
Local property tax & 0.25 & 0.50 \\
Excises & 0.21 & 0.21 \\
Vehicle and carbon taxes & 0.16 & 0.18 \\
Personal income taxes & 0.14 & 0.43 \\
Capital taxes & 0.13 & 0.16 \\
Other (net of stimulus measures) & 0.03 & -0.13 \\
Expenditure & 1.72 & 2.20 \\
Health & 0.78 & 1.17 \\
Social Protection & 0.39 & 0.45 \\
Education & 0.09 & 0.12 \\
Agriculture & 0.09 & 0.09 \\
Justice & 0.06 & 0.06 \\
Other & 0.31 & 0.31 \\
Total & 2.93 & 3.90 \\
\hline
\end{tabular}

Source: Budget 2013 - Summary of Tax Measures; Expenditure Report.

\section{The current expenditure package is anchored by the gross nominal} departmental expenditure ceilings for 2013 set in December 2011. Appropriately, the sole exception is for social protection, where an increase of $€ 0.15$ billion is provided to accommodate pressures seen in 2012 arising from higher-than-budgeted unemployment. The $€ 1.7$ billion in new savings to deliver the unchanged ceilings are composed of (i) $€ 0.4$ billion in public sector wage bill reductions, made possible by a targeted reduction in staff numbers of 7,000 relative to the end-2012 ceiling, and productivity gains currently being negotiated with the public service unions; (ii) $€ 0.4$ billion in social welfare adjustments, led by cuts in universal benefits ( $€ 10$ per month reduction in child benefit and reduced free telephone and electricity allowances for the elderly) and shortening the duration of the Jobseeker Benefit entitlement by three months; and (iii) $€ 0.9$ billion from tightening a range of subsidies and programs, predominantly in health. Measures to generate health savings include lower cost drug procurement, reduced fees for services provided by medical professionals, higher co-payments on drugs, a slightly more stringent means test for eligibility to medical cards for persons over 70 years old, and higher charging for private patients in public hospitals 
(MEFP, ๆ4). Key measures in education include reduced allocations for colleges and vocational education centers, a 3 percent higher income threshold for eligibility to college grants, and a 10 percent $(€ 250)$ increase in the annual student contribution to college fees.

\section{If fully implemented, staff considers that these measures can achieve the} program fiscal targets. However, buffers in relation to the fiscal targets appear to have narrowed, and the consolidation depends on many measures which can increase implementation risks, so budget execution will bear close monitoring. On the revenue side, the base for 2012 is modestly lower ( $1 / 4$ percent of GDP) than anticipated during the mission, but higher non-tax revenues are expected to offset the impact on the overall revenue outlook for 2013. Given the challenges with expenditure control in the health sector experienced in 2012, it will be critical to ensure full implementation from the outset of the specified health sector savings and ongoing management of any slippages, especially as some measures have uncertain yields, such as charging private patients in public hospitals. Careful preparation is also needed to ensure smooth introduction of and compliance with the property tax. Moreover, some measures still need to be finalized; in particular, agreement with public sector unions on steps that will ensure additional pay bill savings of at least $€ 0.4$ billion in 2013 (and $€ 1$ billion through 2015) is needed as soon as possible.

\section{The 2013 budgetary package seeks to mitigate the impact of consolidation on growth and the most vulnerable in a manner broadly consistent with staff advice. The} measures to broaden the tax base will strengthen revenues while avoiding adverse incentives from higher marginal tax rates on labor income, consistent with staff's recommendations on growth-friendly consolidation in the 2012 Article IV consultation. At this stage, the overall distributional impact of the budget package is unclear. ${ }^{2}$ In addition to the rise in taxes on interest and on capital gains and acquisitions, staff has earlier supported a number of the budget measures that are expected to be progressive, including the introduction of a property tax, tightening of tax reliefs for private pensions and high-income pensioners, and the extension of PRSI to unearned income. At the same time, some measures also supported by staff impact more equally across income groups, including the removal of the PRSI exemption for the first $€ 127$ of weekly earnings, but persons earning less than $€ 18,304$ are protected. Cuts to universal benefits, strengthened means-tests for medical cards and student grants, and higher college fees, are also broadly consistent with staff's calls for better targeting social supports and subsidies, although staff favored offsets for low income groups.

\footnotetext{
${ }^{2}$ Researchers at the ESRI have prepared an initial analysis of the distributional impact of Budget 2013, although the analysis covers just under one-third of the new measures announced, comprising half of the savings in social welfare and about half of the tax measures. For 2013, the impact of those measures included in the analysis is similar for the middle three income groups, with a reduction in income of 0.9 percent. For the lowest income group, the income reduction is 1.1 percent, while for the top income group it is lower, at 0.6 percent. The researchers expect that inclusion of some omitted income and wealth tax measures would tend to make the impact more progressive, while other omitted measures — such as indirect tax increases — would have a more regressive impact, and the net balance between these factors is a matter for further investigation.
} 
8. Budget 2013 also goes some way in specifying the consolidation over 2014-15, leaving a more manageable requirement for new measures coming budgets. The full year effect of the new tax and expenditure measures announced in Budget 2013 exceeds the yield expected to be generated in 2013, implying a carryover of about $€ 1$ billion annually for outer years. Furthermore, if the negotiations with public sector unions deliver the government's targeted outcome, they will imply $€ 0.5$ billion in additional annual savings over 2014-15. Finally, the authorities' commitment to the European Commission to introduce metered water charging is expected to raise about $€ 0.5$ billion in 2015 . Together with smaller items, these savings amount to $€ 2.2$ billion, just over two-fifths of the programmed consolidation effort of $€ 5.1$ billion for 2014-15, helping to reduce uncertainties for households and businesses. The need to specify additional new measures in the next two budgets is also limited to a relatively manageable $13 / 4$ percent of GDP. Staff sees scope for broadening the income tax base through adjustments in bands and credits, potential further pay and pension bill savings, and better targeting social supports and subsidies to protect the vulnerable, including further steps to reduce growth in age-related spending.

\section{Other financial and real sector developments since the issuance of the staff report to the Board do not change the thrust of staff assessment:}

- $\quad$ High frequency indicators appear consistent with low growth of just under $1 / 2$ percent in 2012. Consumer sentiment improved in the last two months following the September decline, registered unemployment declined to 14.6 percent in November, and PMIs remain strong, especially in the services sector. On the other hand, in October industrial production rose only modestly from the sharp slump in September that was focused on chemical and pharmaceutical products.

- Irish government bond spreads relative to bunds have widened about 35 basis points on the 9-year benchmark, broadly in line with other euro area sovereign bonds. The National Treasury Management Agency announced that it has acquired holdings of bonds maturing in April 2013, and has cancelled $€ 0.5$ billion, reducing the principal outstanding on this issue to $€ 5.1$ billion.

- The authorities are seeking a one year extension of the Eligible Liability Guarantee scheme through 2013. At the same time, they are preparing for the possibility of phasing out the scheme by mid- 2013 .

- $\quad$ Newly available data on mortgage approvals show some pick-up since mid-2012, albeit from a very low base, with year-to-date approvals of residential mortgages up by 9 percent $y / y$. Nonetheless, the total value of approvals of $€ 2.4$ billion represents just about 2 percent of the outstanding stock of mortgages. 


\title{
INTERNATIONAL MONETARY FUND
}

\author{
IRELAND \\ Eighth Review Under the Extended Arrangement-Further Supplementary \\ Information
}

Prepared by the European Department

(In consultation with other departments)

Approved by Ajai Chopra and Lorenzo Giorgianni

December 14, 2012

\section{This supplement provides an update on data on residential mortgage arrears} and repossessions released since the issuance of a supplement to the staff report on December 12, 2012 (EBS/12/157, Supplement 1). The Central Bank of Ireland published these statistics for the third quarter on December 13, with an expanded release covering buy-to-let (BTL) properties in addition to principal dwelling houses (PDH). Some data for previous quarters included in the staff report (EBS/12/157, page 6) are revised.

\section{Household mortgage arrears data show a continuing increase in mortgage} delinquency, although early arrears appear to be stabilizing. The value of residential mortgages in arrears for over 90 days rose in the third quarter to 15.1 percent of total mortgage loans, up from 14.1 at end-June. Early arrears cases (less than 90 days in arrears), once corrected for the impact of technical factors, declined as seen in the previous two quarters. Repossessions and voluntary surrenders continued at about 150 per quarter, similar to the pace in 2011.

A fall in the share of

restructured

mortgages is largely

a reclassification

effect, and about

half of restructures

are payments of

interest only or

reduced payments

that are smaller than

interest only.

\begin{tabular}{lrrrrrr}
\multicolumn{1}{l}{ Ireland: Residential Mortgage Arrears (Billions of euros) 1 / } \\
\hline & Dec-09 & Dec-10 & Dec-11 & Mar-12 & Jun-12 & Sep-12 \\
\hline Outstanding & 118.3 & 116.7 & 113.5 & 112.7 & 112.0 & 111.2 \\
Mortgage loans in arrears over 90 days 2/ & 5.3 & 8.6 & 13.7 & 15.0 & $15.84 /$ & 16.8 \\
$\quad$ in percent of outstanding & 4.5 & 7.4 & 12.0 & 13.3 & $14.14 /$ & 15.1 \\
Restructured mortgages & n.a. & 10.4 & 13.3 & 14.2 & 15.1 & 13.9 \\
$\quad$ in percent of outstanding & n.a. & 8.9 & 11.7 & 12.6 & 13.5 & 12.5 \\
Repossessions and voluntary surrenders 3/ & 211 & 574 & 1,182 & 1,352 & 1,498 & 1,652 \\
\hline
\end{tabular}

Source: Central Bank of Ireland.

1/ Private residential mortgage accounts for principal dwellings held in Ireland.

2 / Includes restructured mortgages in arrears over 90 days.

3/ Cumulative number since 2009Q3.

4/ Revised as of December 2012.

\section{Residential mortgage accounts for BTL properties show greater impairment.}

Mortgages in arrears of more than 90 days accounted for 25.5 percent of total BTL mortgage loans by end September, up from 23.9 percent at end June. The higher rate of arrears on BTL mortgages compared with PDH mortgages is reflected in the significantly higher loss rates on BTL mortgages allowed for in the 2011 bank recapitalization exercise (Prudential Capital Assessment Review 2011, page 21). 
Press Release No. 12/491

FOR IMMEDIATE RELEASE

December 17, 2012
International Monetary Fund

Washington, D.C. 20431 USA

\section{IMF Completes Eighth Review Under the Extended Fund Facility with Ireland and Approves €0.89 billion Disbursement}

The Executive Board of the International Monetary Fund (IMF) today completed the eighth review of Ireland's performance under an economic program supported by a three-year, SDR 19.4658 billion (about $€ 22.79$ billion or about US $\$ 29.99$ billion) arrangement under the Extended Fund Facility (EFF), or the equivalent of about 1,548 percent of Ireland's IMF quota. The completion of the review enables the disbursement of an amount equivalent to SDR 0.758 billion (about $€ 0.89$ billion or about US $\$ 1.17$ billion), bringing total disbursements under the EFF to SDR 16.5434 billion (about $€ 19.37$ billion or about US\$25.49 billion).

The arrangement for Ireland, which was approved on December 16, 2010 (see Press Release No. 10/496), is part of a financing package amounting to $€ 85$ billion (about US\$111.9 billion), also supported by the European Financial Stabilization Mechanism and European Financial Stability Facility, bilateral loans from Denmark, Sweden, and the United Kingdom, and Ireland's own contributions.

Ireland's steadfast policy implementation has continued even as growth has slowed in 2012. The 2012 outturn should be comfortably within the 8.6 percent deficit target despite health overruns and higher social welfare spending owing to high unemployment. The budget for 2013 was recently submitted to parliament, setting out a combination of durable spending and revenue measures of over 2 percent of GDP to reduce the deficit to 7.5 percent of GDP.

The Irish authorities are also advancing reforms to help revive growth. In the financial sector, they are supervising banks' efforts to reduce loans in arrears and are adopting insolvency reforms for highly indebted households and SMEs. To rebuild bank profitability they are preparing for the possibility of phasing out the guarantee scheme and are monitoring reductions in banks' operational costs. To avoid high unemployment becoming more structural, the authorities are intensifying engagement with unemployed persons, reforming further education, and revamping housing supports. 
Market conditions for Irish sovereign debt are much improved following the June 29, 2012 announcement that the Eurogroup is examining the situation of the Irish financial sector with a view to further improving the sustainability of Ireland's well-performing program, and also of Outright Monetary Transactions by the ECB. Together with Ireland's strong policy implementation, these developments have enabled Irish sovereign yields to decline notably in 2012 and allowed Ireland to access significant market funding in the second half of the year.

Looking ahead, however, a more gradual economic recovery is projected, with growth of 1.1 percent in 2013 and 2.2 percent in 2014, with public debt expected to peak at 122 percent of GDP in 2013. This baseline outlook is subject to significant risks from any further weakening of growth in Ireland's trading partners, while the gradual revival of domestic demand could be impeded by high private debts, drag from fiscal consolidation, and banks still limited ability to lend. If growth were to remain low in coming years, public debt could continue to rise, in part reflecting the potential for renewed bank capital needs to emerge.

Following the Executive Board's discussion, Mr. David Lipton, First Deputy Managing Director and Acting Chair, said:

"The program with Ireland has now been in place for two years and the Irish authorities have consistently maintained strong policy implementation. All program targets have been met and a range of fiscal, financial, and structural reforms are in train. Aided by the commitments of European partners, Irish bond yields have declined, allowing Ireland to begin its return to market financing.

"The authorities have demonstrated their commitment to put Ireland's fiscal position on a sound footing, with the 2012 deficit target expected to be met even through growth has been low. The Medium-Term Fiscal Statement set out a phased path for considerable further fiscal consolidation to bring the budget deficit below 3 percent by 2015 . The 2013 budget provides a key step along that path, and full implementation is needed. Nonetheless, if next year's growth were to disappoint, any additional fiscal consolidation should be deferred to 2015 to protect the recovery.

"Vigorous implementation of financial sector reforms is needed to revive sound bank lending in support of economic growth. Key steps forward include arresting the deterioration of banks' asset quality, reducing their operating costs, and lowering funding costs through orderly withdrawal of guarantees. The personal insolvency reform being adopted should facilitate out-of-court resolution of household debt distress, especially if complemented by a well functioning repossession process to help maintain debt service discipline and underpin banks' willingness to lend.

"Continued strong Irish policy implementation is essential for the program's success. Ireland's market access would also be greatly enhanced by forceful delivery of European pledges to improve program sustainability, especially by breaking the vicious circle between 
the Irish sovereign and the banks. By supporting medium term growth and debt reduction prospects, this would help avoid prolonged reliance on official financing." 